OAK RIDGE NATIONAL LABORATORY

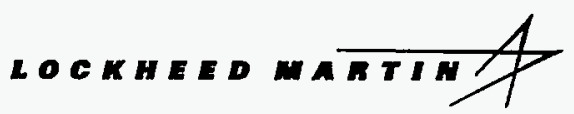

MANAGED AND OPERATED BY LOCKHEED MARTH ENERGY RESEARCH CORPORATION FOR THE UNTED STATES DEPARTMENT OF ENERGY
F. G. Gardner

P. M. Kearl

M. E. Mumby

S. Rogers
Hydrogeologic Investigation of the

Advanced Coal Liquefaction Research and Development Facility Wilsonville, Alabama
( ) 5

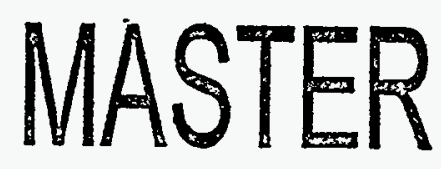


This report has been reproduced directly from the best available copy.

Available to DOE and DOE contractors from the Office of Scientific and Technical Information, P. O. Box 62, Oak Ridge, TN 37831; prices available from (423) 576-8401, FTS 626-8401.

Available to the public from the National Technical Information Service, U.S. Department of Commerce, 5285 Port Royal Road, Springfield, VA 22161.

This report was prepared as an account of work sponsored by an agency of the United States Government. Neither the United States Government nor any agency thereof, nor. any of their employees, makes any warranty, express or implied, or assumes any legal liability or responsibility for the accuracy, completeness, or usefulness of any information, apparatus, product, or process disclosed, or represents that its use would not infringe privately owned rights. Reference herein to any specific commercial product, process, or service by trade name, trademark, manufacturer, or otherwise, does not necessarily constitute or imply its endorsement, recommendation, or favoring by the United States Government or any agency thereof. The views and opinions of authors expressed herein do not necessarily state or reflect those of the United States Government of any agency thereof. 


\title{
Hydrogeologic Investigation
} of the

\section{Advanced Coal Liquefaction Research and Development Facility Wilsonville, Alabama}

\author{
F. G. Gardner \\ P. M. Kearl \\ M. E. Mumby \\ S. Rogers
}

\section{Published:}

Prepared for

U.S. Department of Energy

Pittsburgh Energy Technology Center

Prepared by:

Oak Ridge National Laboratory

Environmental Technology Section

P.O. Box 2567

Grand Junction, Colorado 81502

Managed by:

Lockheed Martin Energy Systems, Inc

for the

U.S. Department of Energy

under contract No. DE-AC05-840R21400 


\section{DISCLAIMER}

Portions of this document may be illegible in electronic image products. Images are produced from the best available original document. 


\section{Contents}

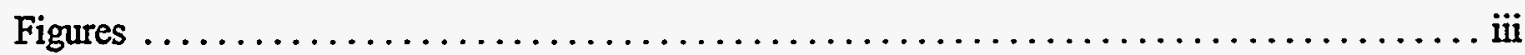

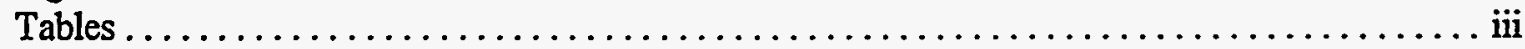

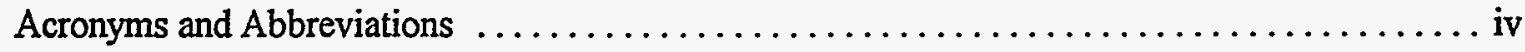

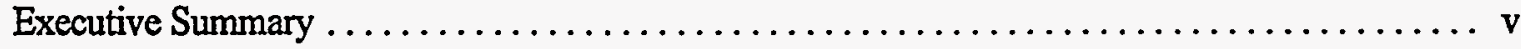

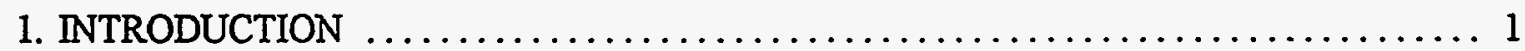

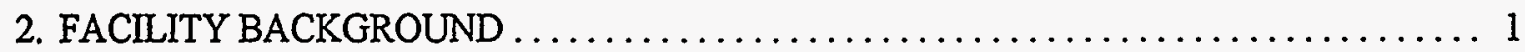

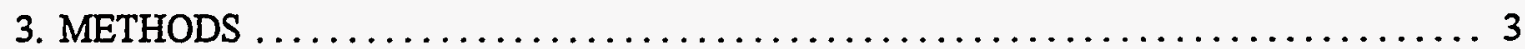

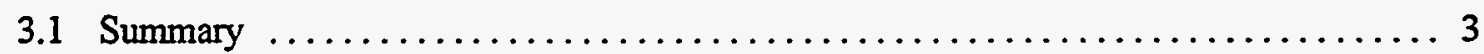

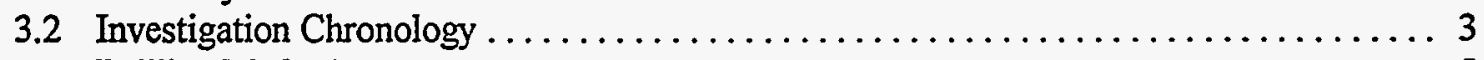

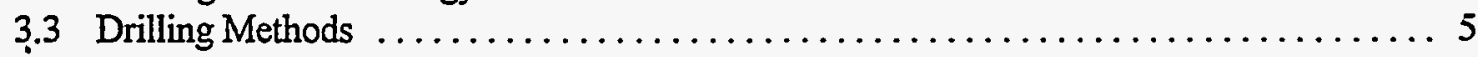

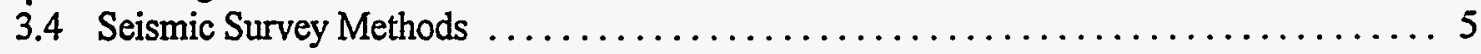

4. REGIONAL GEOLOGY AND HYDROGEOLOGY $\ldots \ldots \ldots \ldots \ldots \ldots \ldots \ldots \ldots \ldots$

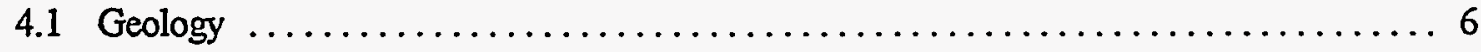

4.2 Regional Hydrogeology $\ldots \ldots \ldots \ldots \ldots \ldots \ldots \ldots \ldots \ldots \ldots \ldots \ldots \ldots \ldots$

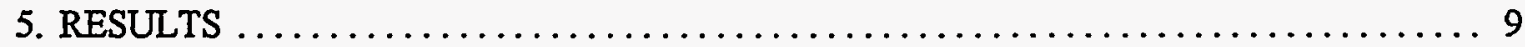

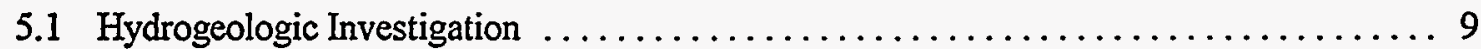

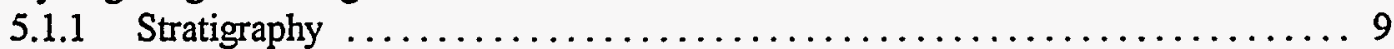

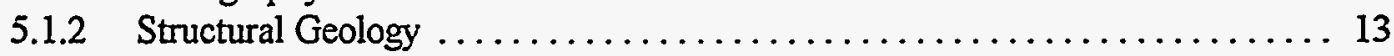

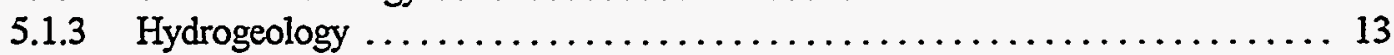

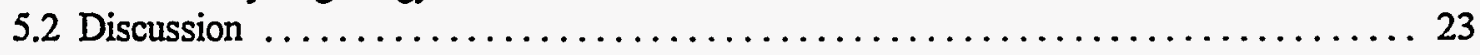

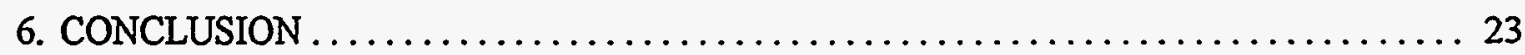

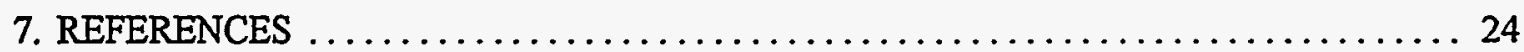

APPENDIX MONITORING WELL, BEDROCK WELL, PIEZOMETER, AND SOIL BORING LOGS 
. 


\section{Figures}

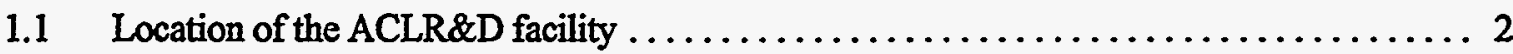

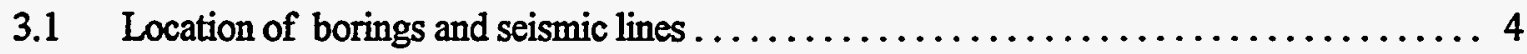

4.1 Physiographic location of the Coosa deformed belt $\ldots \ldots \ldots \ldots \ldots \ldots \ldots \ldots \ldots 7$

4.2 Stratigraphic column for the rocks of Shelby County $\ldots \ldots \ldots \ldots \ldots \ldots \ldots \ldots \ldots$

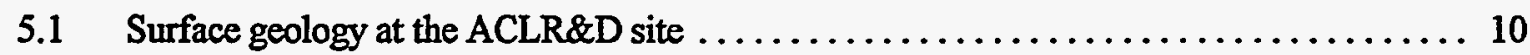

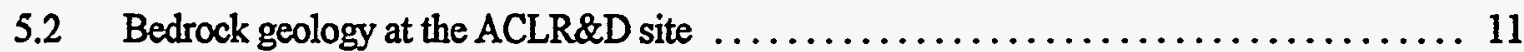

5.3 Cross section $A-A^{\prime}$ illustrating the overturned fold $\ldots \ldots \ldots \ldots \ldots \ldots \ldots \ldots \ldots 14$

5.4 Cross section $B-B^{\prime}$ illustrating the strike-slip fault $\ldots \ldots \ldots \ldots \ldots \ldots \ldots \ldots \ldots \ldots$

5.5 Bedrock contour map ................................... 16

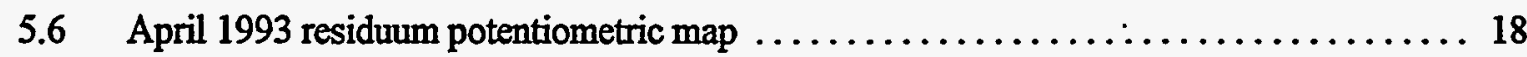

5.7 May 1993 bedrock potentiometric map ............................. 20

\section{Tables}

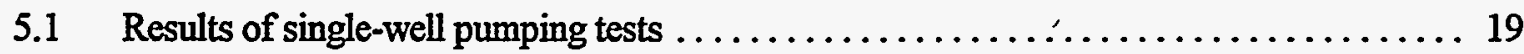

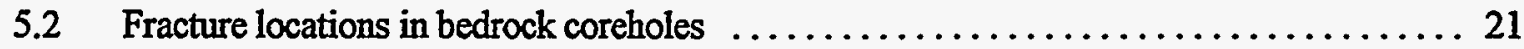

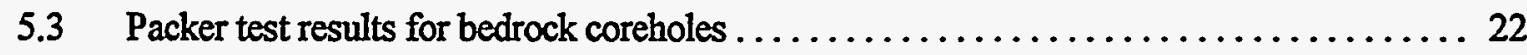


. 


\section{Acronyms and Abbreviations}

$\begin{array}{ll}\text { ACLR\&D } & \text { Advanced Coal Liquefaction Research \& Development } \\ \text { bgs } & \begin{array}{l}\text { below ground surface } \\ \text { common depth point }\end{array} \\ \text { CDP } & \begin{array}{l}\text { Comprehensive Environmental Response, Compensation, } \\ \text { and Liability Act }\end{array} \\ \text { CERCLA } & \text { day } \\ \text { d } & \text { U.S. Department of Energy } \\ \text { DOE } & \text { feet } \\ \text { ft } & \text { Grand Junction } \\ \text { GJ } & \text { hollow stem auger } \\ \text { HSA } & \text { inside diameter } \\ \text { i.d. } & \text { inches } \\ \text { in. } & \text { mean sea level } \\ \text { msl } & \text { Oak Ridge National Laboratory } \\ \text { ORNL } & \text { Pittsburgh Energy Technology Center } \\ \text { PETC } & \text { polyvinyl chloride } \\ \text { PVC } & \text { remedial investigation } \\ \text { RI } & \text { Southern Clean Fuels } \\ \text { SCF } & \text { Southern Company Services } \\ \text { SCS } & \text { thermal liquefaction unit } \\ \text { TLU } & \end{array}$




\section{EXECUTIVE SUMMARY}

A hydrogeologic site characterization was conducted at the former Advanced Coal Liquefaction Research and Development facility in Wilsonville, Alabama, by the Oak Ridge National Laboratory Grand Junction office for the U. S. Department of Energy Pittsburgh Energy Technology Center. This characterization provided baseline environmental information necessary for closeout of facility operations.

The hydrogeologic assessment was non-routine because of the unusual structural complexity of the subsurface. Bedrock drilling demonstrated that both an overturned fold and a strike-slip fault are present beneath the site. Moreover, the site is also underlain by limestone that contains solution cavities. However, it was determined that potential groundwater contamination in the residuum is not a threat to the environment and that groundwater in the limestone aquifers is not flowing toward potential receptors. 


\section{INTRODUCTION}

This document describes the geology and hydrogeology at the former Advanced Coal Liquefaction Research and Development (ACLR\&D) facility in Wilsonville, Alabama. The work was conducted by personnel from the Oak Ridge National Laboratory Grand Junction office (ORNL/GJ) for the U.S. Department of Energy (DOE) Pittsburgh Energy Technology Center (PETC). Characterization information was requested by PETC to provide baseline environmental information for use in evaluating needs and in subsequent decision-making for further actions associated with the closeout of

facility operations. The hydrogeologic conceptual model presented in this report provides significant insight regarding the potential for contaminant migration from the ACLR\&D facility and may be useful during other characterization work in the region.

The ACLR\&D facility is no longer operational and has been dismantled. The site was characterized in three phases: the first two phases were an environmental assessment study and a soil sampling study (APCO 1991) and the third phase the hydraulic assessment. Currently, a Comprehensive Environmental Response, Compensation, and Liability Act (CERCLA) remedial investigation (RI) to address the presence of contaminants on the site is underway and will be documented in an RI report. This technical memorandum addresses the hydrogeologic model only.

\section{FACILITY BACKGROUND}

The ACLR\&D facility is located in the eastern portion of Shelby County in north-central Alabama. The facility lies immediately west of the E. C. Gaston Steam Plant located on the west bank of the Coosa River near the confluence with Yellow Leaf Creek (Fig. 2.1).

The ACLR\&D facility was constructed in 1974 by the Electric Power Research Institute as a pilot plant to develop clean-burning, coal-derived fuels from high-sulfur, high-ash coal. DOE support of facility operations began in 1976 (SCS 1991). Catalytic, Inc., later Catalytic Division of United Engineers and Constructors, operated the facility from inception to August 1988 when Southern Company Services (SCS) assumed responsibility for the site. A subsidiary of SCS, Southern Clean Fuels (SCF) division of Southern Electric International, was the subcontractor providing operations and maintenance support. SCS is currently conducting the CERCLA RI at the facility.

Over the course of the Phase III investigation performed by ORNL/GJ, the facility was decommissioned and demolished by SCS. The only remaining structures and utilities are the main office building and the sewage treatment plant. 


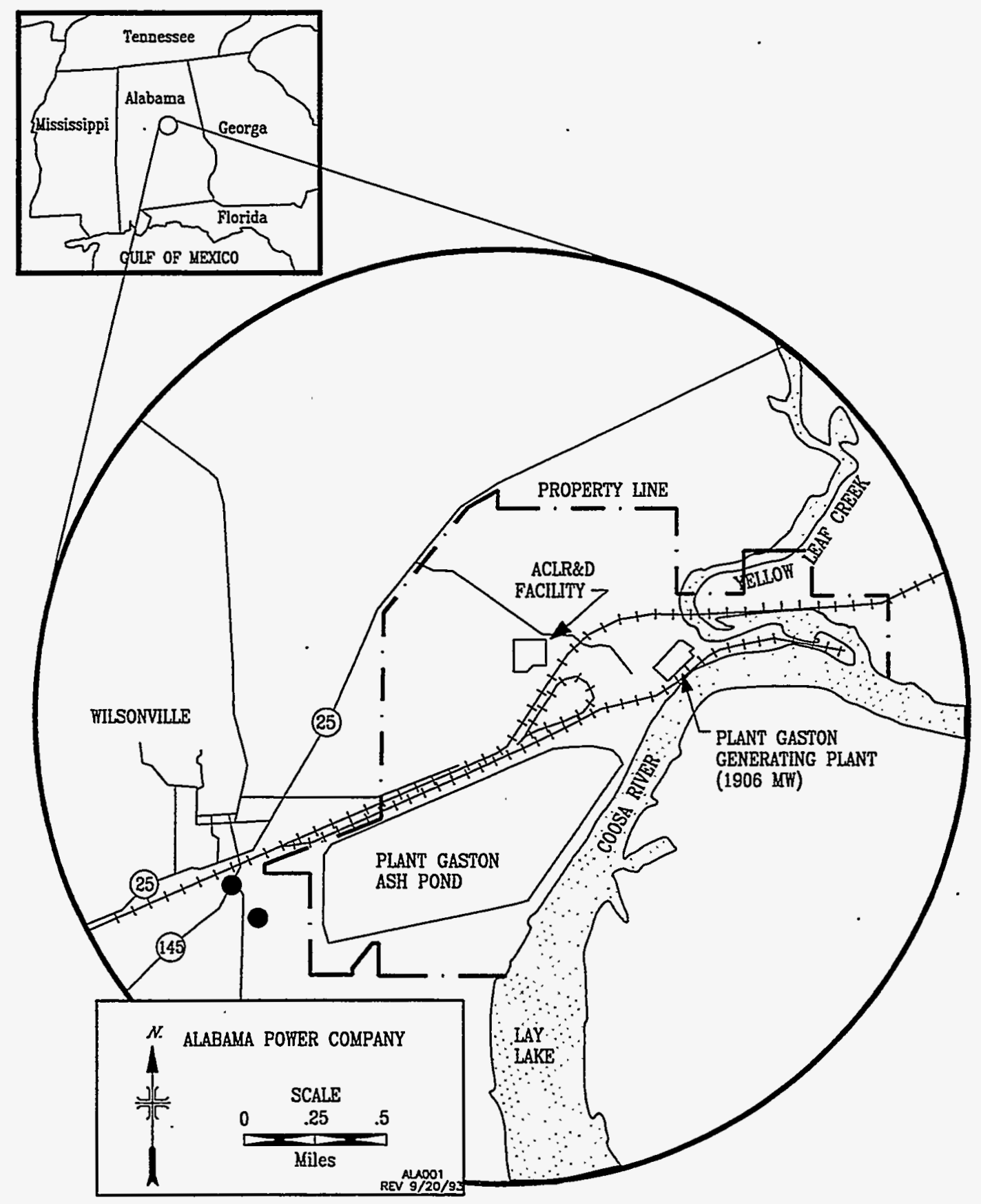

Wilsonville Water Supply Well

Fig. 2.1. Location of the ACLR\&D facility. 


\section{METHODS}

\subsection{Summary}

The Phase III investigation consisted of the following components: 1) a geologic investigation to delineate the complex structure and stratigraphy at the site, 2) extensive soil sampling to delineate the lateral and vertical extent of any potential contamination, and 3) installation of piezometers, monitoring wells, and bedrock wells to determine groundwater flow directions and to obtain groundwater quality data. Because the results of soil and groundwater analysis are being evaluated in the on-going $\mathrm{RI}$, only the methods used to conduct the hydrogeologic investigation are described below.

\subsection{Investigation Chronology}

Eighty-eight holes were drilled during Phase III field work between May 1992 and June 1993. The borings included 6 piezometers, 15 monitoring wells, 55 boreholes, and 12 coreholes. Presented below is a brief summary of what was accomplished during each of the field efforts.

May 1992: Twenty-five holes were drilled. Of these, three were completed as piezometers (PZ04, PZ08, and PZ09), and three were completed as monitoring wells (MW05, MW07, and MW15). The rest of the holes were borings drilled to a maximum depth of $16 \mathrm{ft}$.

June 1992: Thirteen holes were drilled. Of these, one was a bedrock corehole (CH36), four were completed as monitoring wells (MW26, MW32, MW35, and MW37), and eight holes were soil borings to a maximum depth of $16 \mathrm{ft}$.

October 1992: Twenty holes were drilled. Of these, three were completed as piezometers (PZ49, PZ52 and PZ57), and 17 were soil borings drilled to auger refusal at the top of bedrock.

December 1992: A shallow seismic reflection study was completed that consisted of a common depth point (CDP) survey using an 8-gauge auger gun at a total of 500 stations separated by $4 \mathrm{ft}$ along three connecting lines.

April 1993: Nineteen holes were drilled. Eight holes were completed as monitoring wells (MW59, MW60, MW61, MW62, MW63, MW64, MW72, and MW73), and 11 were soil borings drilled to auger refusal at the top of bedrock. MW61 was installed to replace $M W 15$, which was destroyed during decommissioning of the ACLR\&D facility.

May 1993: $\quad$ Eleven bedrock coreholes were drilled to characterize the underlying structure and stratigraphy. Depth of these varied significantly due to rock type and structure.

The above referenced drilling locations are illustrated in Fig. 3.1. 


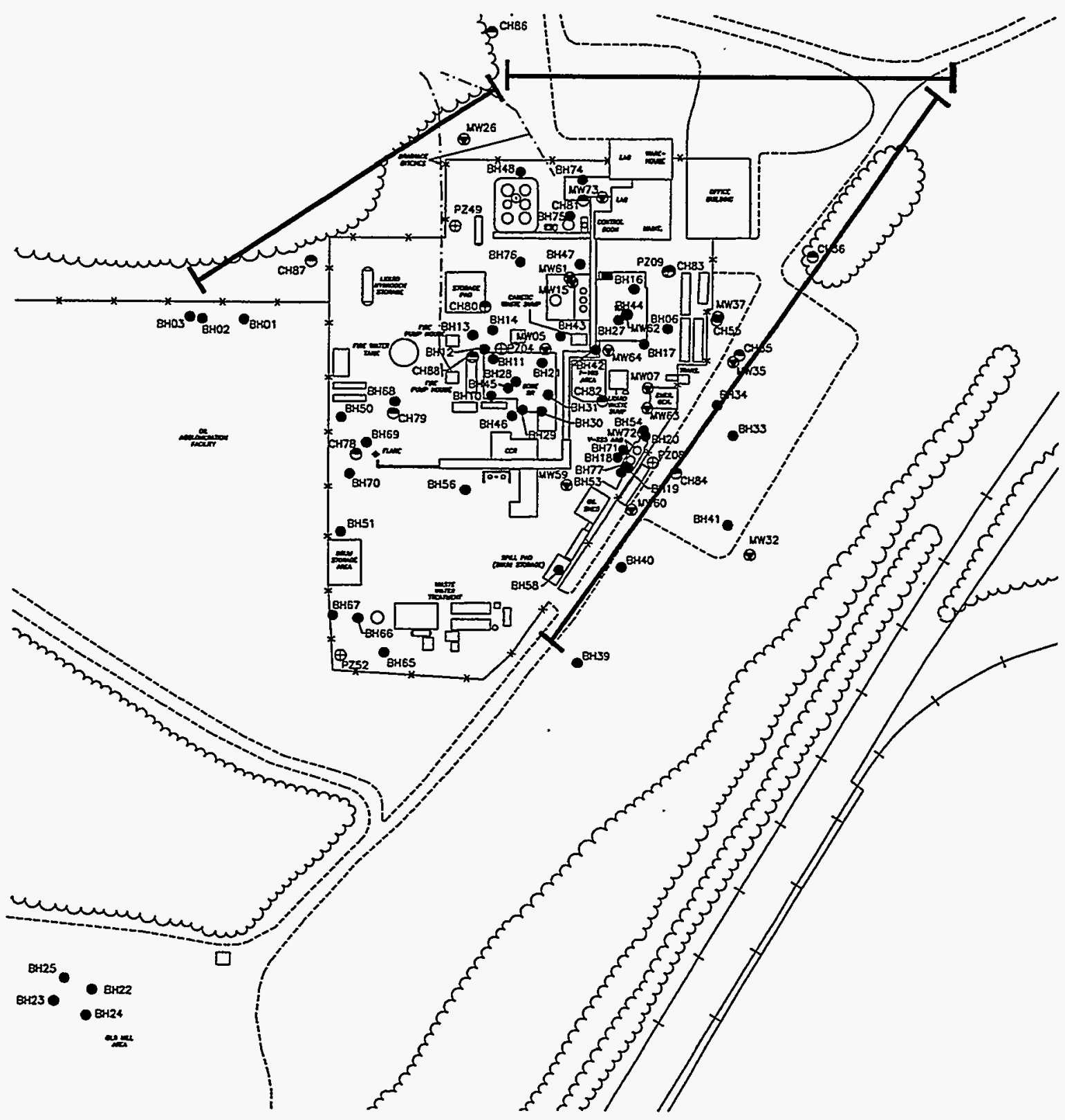

Southern Clean Fuels Wilsonville, Alabama
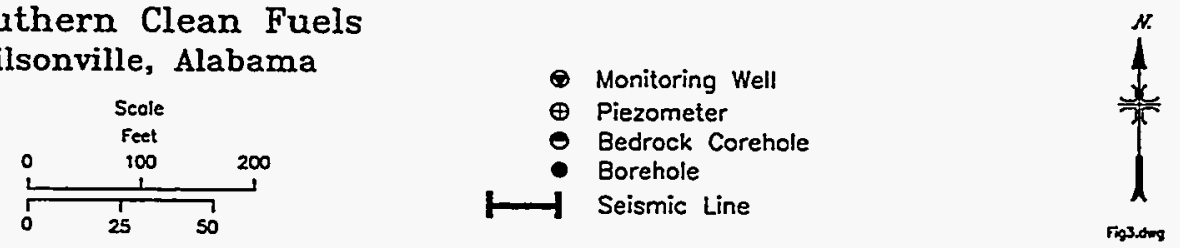

Fig. 3.1. Location of borings and seismic lines. 


\subsection{Drilling Methods}

Two types of drilling methods were used during the course of the investigation. Hollow stem augers (HSAs) were used to drill and sample weathered overburden materials (residuum). Generally, 41/1in.-i.d. (inside diameter) HSAs were used in conjunction with $2 \frac{1}{2} 2$-in.-i.d. by 24 -in.-long split-spoon samplers equipped with four 6-in. brass sleeves. Samples were collected at 5-ft intervals. Bedrock coring was performed using a standard NX-size wireline core barrel that provided continuous rock cores.

Monitoring wells were constructed with 2-in.-i.d. schedule-40 polyvinyl chloride (PVC) pipe and screen. A 0.010-in., machine-slotted screen size was used on all piezometers and monitoring wells. The monitoring wells and annular materials were installed through the augers. Generally, a 5 -ft screened interval was used, but on several occasions, 15- to 20-ft screened intervals were installed to intercept perched water above the bedrock-residuum interface. The annular space was filled with 16to 20-graded silica sand to at least $3 \mathrm{ft}$ above the top of the screen. A 3-ft bentonite seal was then emplaced using bentonite chips. The remainder of the annulus was filled to the surface with a cementbentonite grout consisting of 6 parts cement to 1 part bentonite. The PVC riser was covered with a protective steel casing (6- or 8-in. diameter) equipped with a hinged locking device and cemented in place. Three steel posts were located radially around the riser and cemented in place. Additionally, a number of wells and piezometers were completed in below-grade, traffic-rated vaults to accommodate the site decommissioning activities. All overburden lithology and rock cores were logged by experienced geologists. Drilling logs and completion records for soil borings, piezometers, monitoring . wells, and bedrock coreholes are presented in the appendix.

Monitoring wells and piezometers were developed to various degrees. Due to the low permeability of the overburden and the limited available groundwater, most of the development was performed using a surge block and a bailer. In two cases (MW07 and MW37), sufficient water was available to allow pumping with a submersible electric pump.

Monitoring well installation, lithological logging, and well development were accomplished using the procedures described in the ORNL Environmental Technology Section procedures manual (ORNL 1993).

\subsection{Seismic Survey Methods}

Data acquisition for a shallow seismic-reflection study was completed in December 1992. The geophysical study consisted of a CDP survey using an 8-gauge auger gun at a total of 500 stations separated by $4 \mathrm{ft}$ along three connecting lines. Figure 3.1 shows the locations of the three seismic lines.

Factors such as cultural noise interference (utilities and facility dismantling operations), a very attenuative near-surface (gravel road base), and low overall signal to noise ratios (poor signal reception over noise from seismic source) contributed to low data quality. Hence, the survey proved inconclusive.

A description of the methods used and results of the seismic-reflection survey are presented by Miller et al. (1993). 


\section{REGIONAL GEOLOGY AND HYDROGEOLOGY}

\subsection{Geology}

The ACLR\&D site is located within the Coosa deformed belt of the Coosa Valley and Ridge district of the Alabama Valley and Ridge physiographic section (Fig. 4.1). The Coosa deformed belt is a structurally complex sequence of Paleozoic-age sedimentary rocks. The geologic sequence ranges in age from Cambrian to Mississippian. The stratigraphic column for rocks that outcrop in Shelby County is shown in Fig. 4.2. The Cambrian and Ordovician rocks consist primarily of carbonates, while the Mississippian rocks are comprised of cherty limestones, sandstones, and shales. A thin unit of Devonian sandstone is also present in the Wilsonville area. The following stratigraphic descriptions of the formations pertinent to this investigation are taken from Thomas and Drahovzal (1974).

The oldest geologic group that outcrops in the region is the Knox Group, which is upper Cambrian to lower Ordovician in age. The Cambrian Copper Ridge Formation of the Knox Group outcrops south of the site where it has been thrust over Mississippian rocks. The unweathered Copper Ridge Formation is a light- to medium-gray, fine-crystalline, massive, siliceous dolomite that weathers to reddishbrown silty clays.

The Knox Group is overlain by a sequence of Ordovician carbonates: in ascending order, the Newala, Lenoir, and Little Oak Limestones, and the Athens Shale. The Newala Limestone consists of dark-gray to pearl-gray to bluish-gray, fine-crystalline, thick-bedded limestone that may contain dolomitic beds lending a mottled appearance. The overlying Lenoir Limestone is a dark-gray, finecrystalline, medium- to thick-bedded limestone. Overlying the Lenoir is the Little Oak Limestone, the youngest of the Ordovician carbonates in the region. The Little Oak Limestone is a dark-gray, coarse-crystal-line, thick-bedded, cherty limestone. The chert is usually black and forms thin, discontinuous beds

in fresh outcrops. The Athens Shale is a facies-equivalent of the Little Oak Limestone in numerous areas of Shelby County. Unweathered Athens Shale consists of a dark-gray to black fissile shale with occasional thin beds of argillaceous limestone.

The Ordovician Formations are unconformably overlain by rocks of Devonian age. The Devonian is represented by the Frog Mountain Sandstone and the Chattanooga Shale. Both units are very thin in Shelby County and are absent in many areas.

The Frog Mountain Sandstone consists of medium-bedded, fine- to coarse-grained quartz sandstone. The Chattanooga Shale consists of black, fissile shale that contains low-grade uranium and pyrite.

Three Mississippian units unconformably overlie the Devonian formations (Fig. 4.2). The three Mississippian units present in the Coosa deformed belt are the Fort Payne chert, the Floyd Formation, and the Parkwood Formation. Due to lithologic similarities, the Floyd and Parkwood Formations are usually mapped as one unit.

The Fort Payne is the oldest Mississippian formation mapped in the Coosa belt. The Fort Payne consists of a light-gray, fine-crystalline, very siliceous limestone. It may be fossiliferous at various localities, containing primarily crinoid stem columns. 


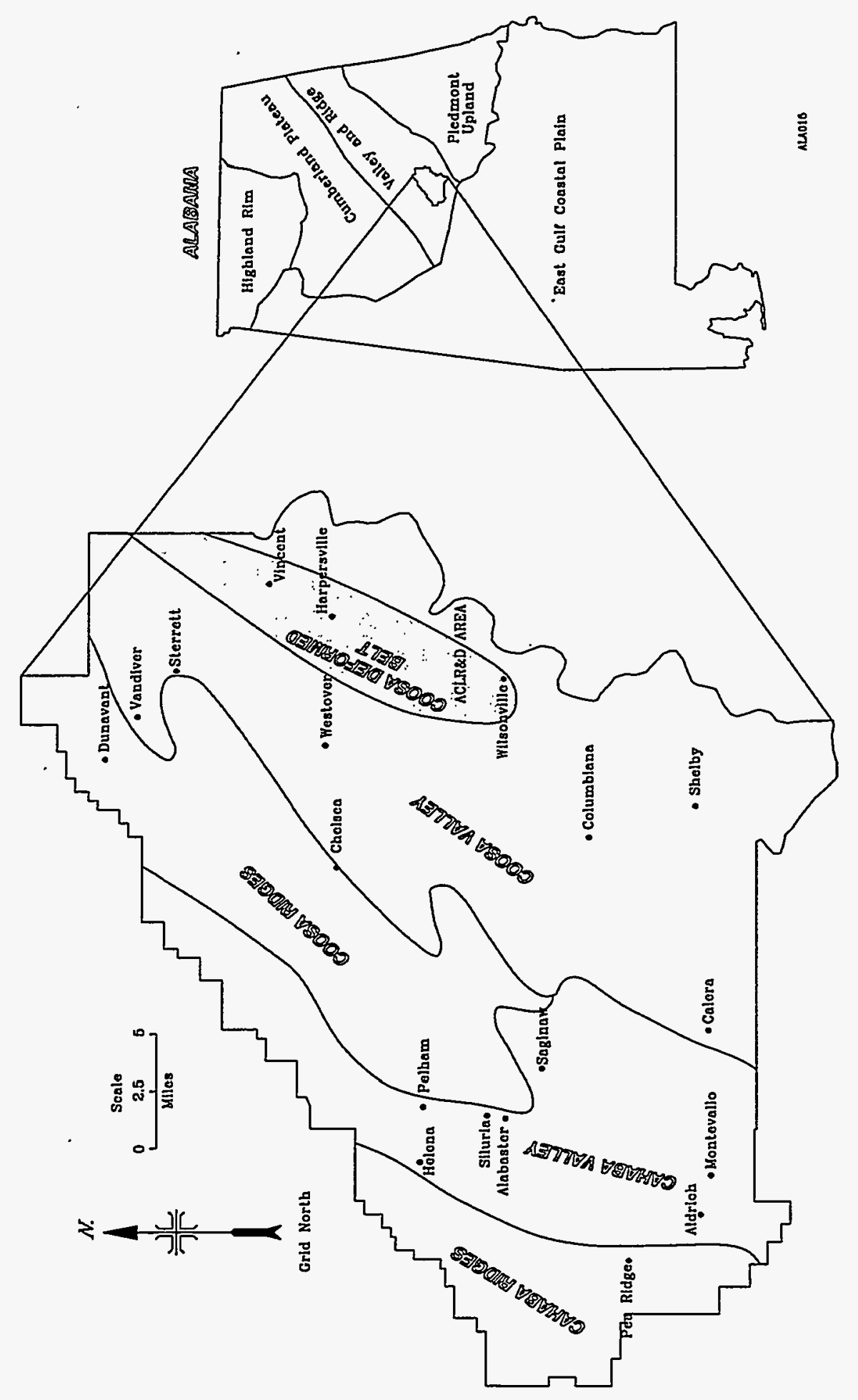

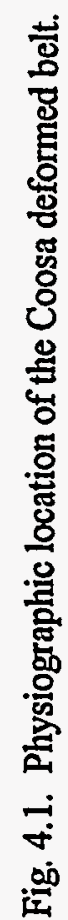



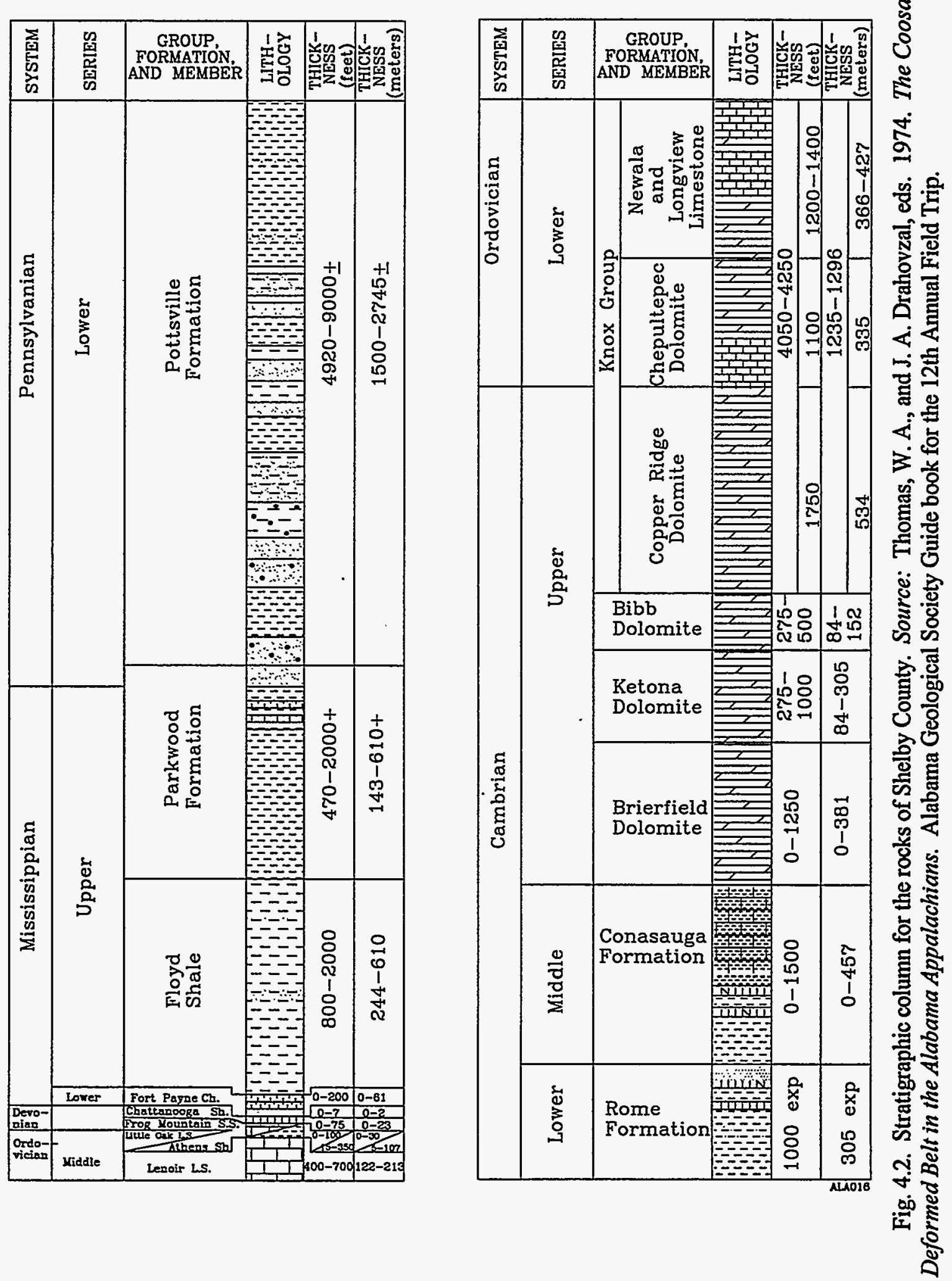
The Floyd and Parkwood Formations overlie the Fort Payne. Both are composed of dark-gray to black fissile shale with occasional beds of interbedded quartz sandstone. The lower portion of the Floyd may contain carbonate units locally.

\subsection{Regional Hydrogeology}

An overview of the regional hydrogeology was taken from Planert and Pritchett (1989). These investigators concluded that the two major regional aquifers are the Knox-Shady of Cambrian-Ordovician age and the Tuscumbia-Fort Payne of Mississippian age. The highest yields from the aquifers are associated with solution openings in carbonate rock. Planert and Pritchett (1989) also determined that fractures in rock materials, due to faulting and the porous, cherty soil resulting from weathering, increase the aquifer's susceptibility to contamination on a local scale.

\section{RESULTS}

\subsection{Hydrogeologic Investigation}

The following sections present the results of the hydrogeologic investigation performed at the ACLR\&D facility. Discussion of results is divided into stratigraphy, structure, and hydrogeology.

\subsubsection{Stratigraphy}

Surface geology at the ACLR\&D consists of weathered remnants of four Paleozoic formations which, in ascending order are: the Ordovician carbonates (undifferentiated in this report), Devonian Frog Mountain Sandstone, Mississippian Fort Payne Limestone, and Mississippian Floyd Shale. Figures 5.1 and 5.2 illustrate the surface and bedrock geology at the site. Most of the site rests on Fort Payne residuum, while the southwest corner overlies weathered Floyd Shale. The north-central and northwest corners of the ACLR\&D site rest on weathered Frog Mountain Sandstone and Ordovician residuum. Descriptions of weathered and unweathered sections of the four Paleozoic formations encountered at the site are presented below.

\subsubsection{Ordovician Carbonates (Undifferentiated)}

The weathered profile of the Ordovician is primarily a yellowish-brown silty clay to clayey silt, depending on depth. Residual silty-clay stringers and manganese oxide nodules are common in the entire weathered interval. Thickness of the weathered zone varies from 20 to $35 \mathrm{ft}$.

The unweathered Ordovician sequence consists primarily of medium- to dark-gray microcrystalline limestone. In areas where the Ordovician is overlain by the Frog Mountain Sandstone, very dark gray to black dolomitic zones give the limestone a mottled appearance. The mottled appearance decreases with depth, and the limestone becomes increasingly argillaceous. Silt-clay laminae and white calcite-healed fractures are common throughout the entire sequence. Fossil content increases with depth where elongated and very deformed sponges are present. Generally, the Ordovician carbonates appear most susceptible to solutioning near the contact with the weathered overburden or where overlain by fractured 


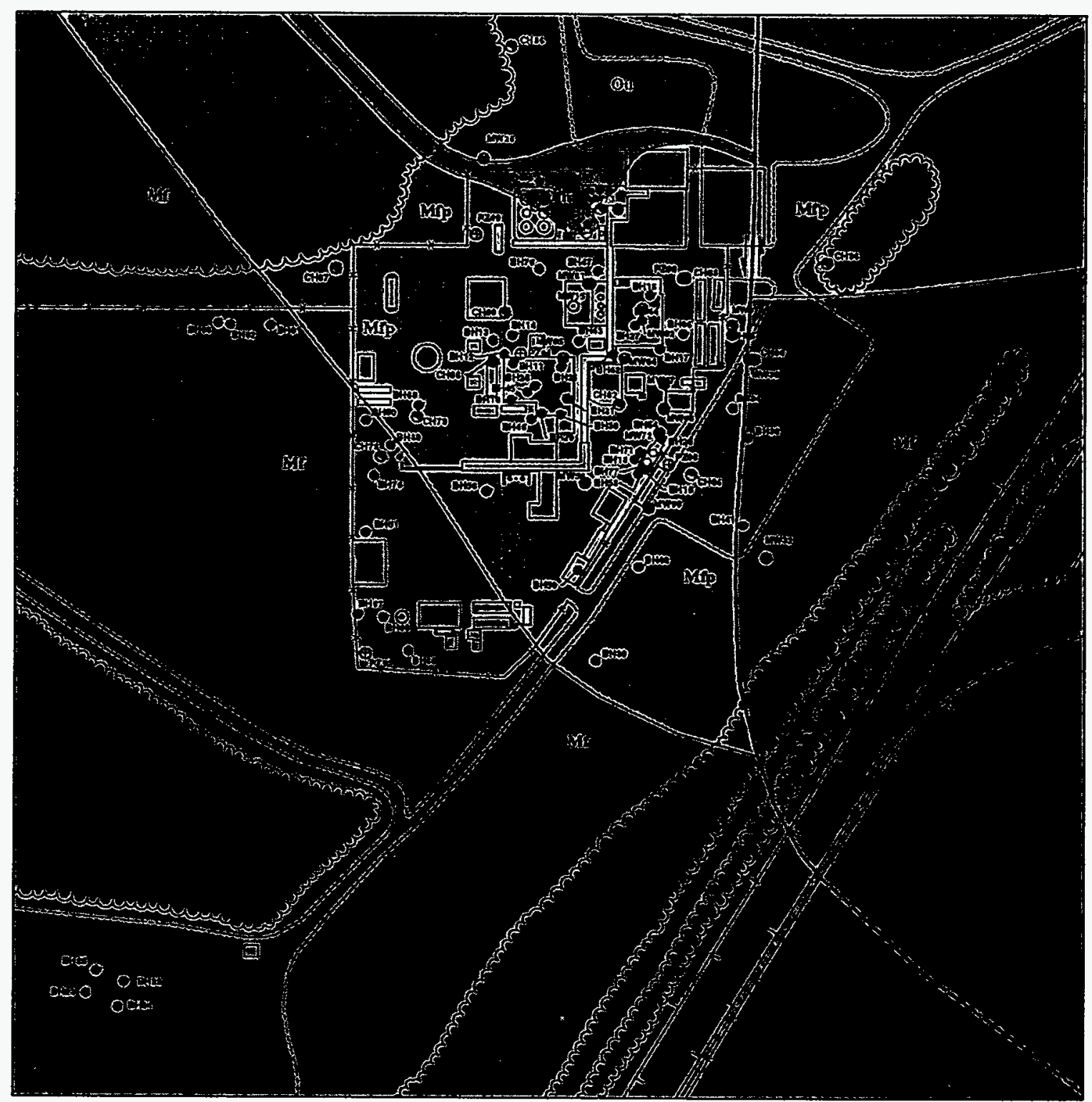

\section{Southern Clean Fuels}

Wilsonville Alabama

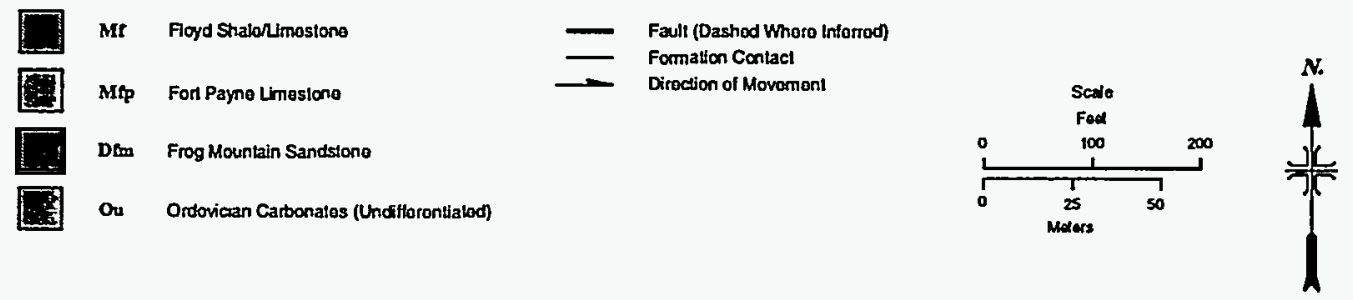

revitions

Fig. 5.1. Surface geology at the ACLR\&D site. 


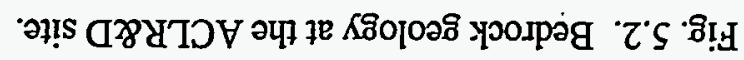

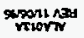
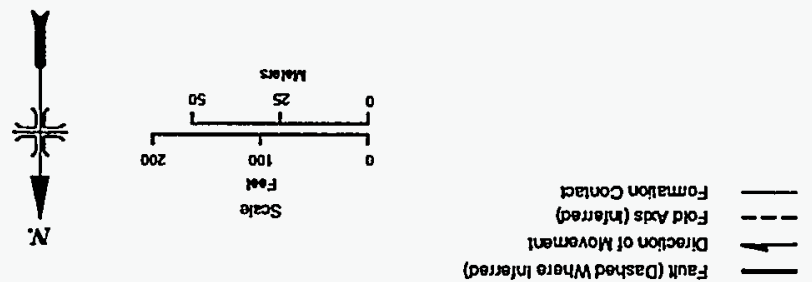

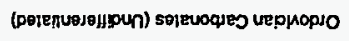

no

Qvolspues uglunow boses

จบolsoun ouked yoy

dง

ougsourngeys pholy

m

вسeqeTV כI!̣uostlM

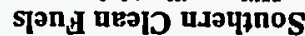

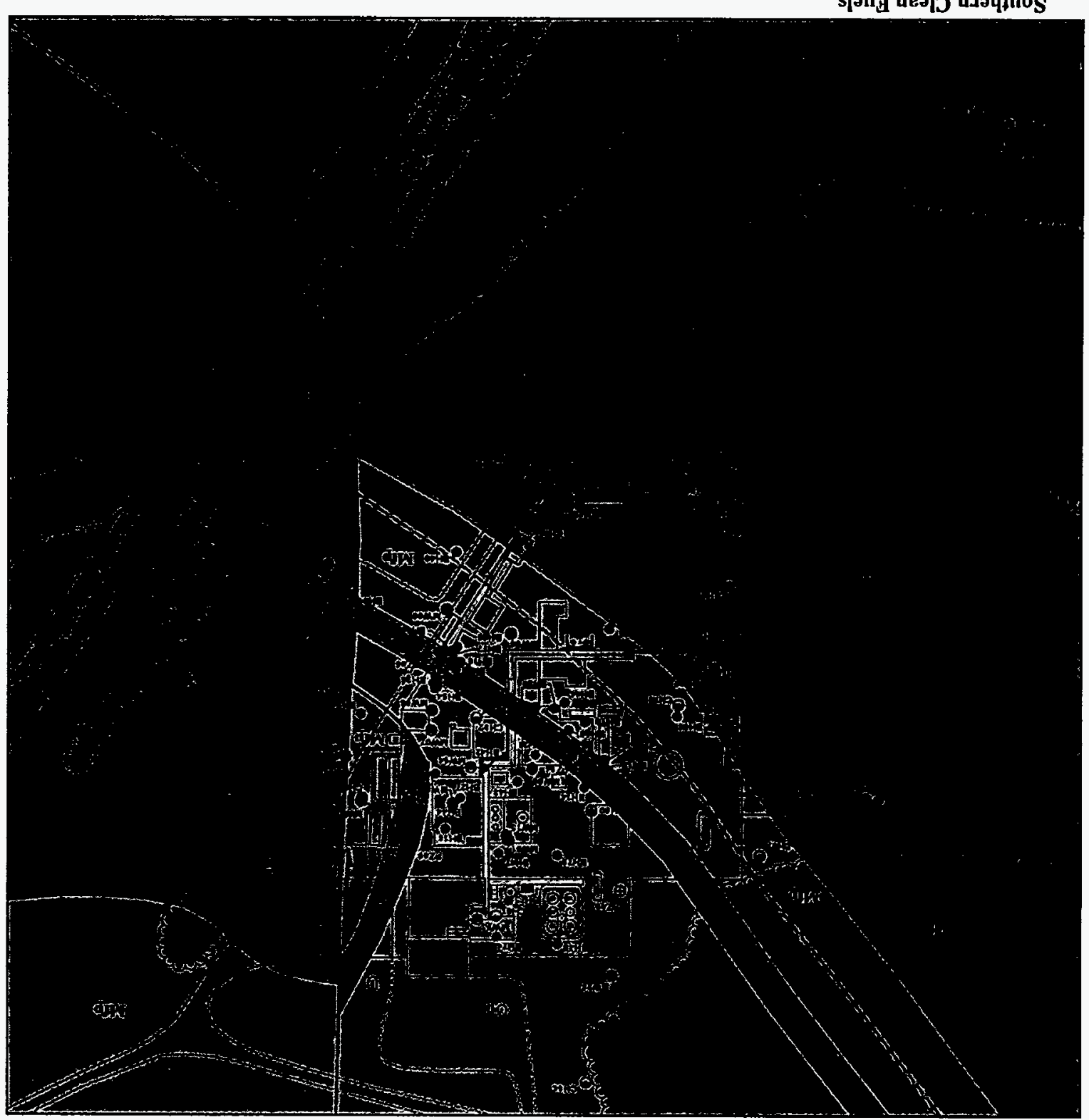


sandstone that is in turn overlain by the weathered overburden. Areas where major structural features are present also appear to influence the degree of solutioning in the Ordovician carbonates.

\subsubsection{Devonian Frog Mountain Sandstone}

The weathered profile of the Frog Mountain Sandstone varies across the site. In areas where the Frog Mountain is only moderately weathered, it consists of a medium to lavender-gray, very fine grained siliceous sandstone (quartzite). In these locations, it was usually impossible to auger through. Where the Frog Mountain is very weathered, it consists of a buff, very fine grained, sub-round to sub-angular, moderately to well-sorted, friable sandstone. Fractures are common, are usually filled with red silty clay, and become more abundant with depth. Frog Mountain thickness varies from 5 to $15 \mathrm{ft}$, depending on the amount of weathering and structure in the immediate area.

The unweathered Frog Mountain Sandstone consists of a very dark gray to black, very fine grained quartzite. The Frog Mountain is extremely hard and brittle and is fractured throughout the entire sequence. Fractures in the Frog Mountain exhibit abundant iron oxide staining and secondary mineral growth, which are indicative of significant fluid movement. These fractures provide pathways for solutioning of the underlying Ordovician carbonates. Drilling in the Frog Mountain was extremely difficult due to the amount of fracturing and the tendency of the formation to cave in.

\subsubsection{Mississippian Fort Payne Limestone}

The Fort Payne Limestone weathers to a red to reddish-yellow silty clay with thin beds and/or cobbles of light-gray to light-gray-blue chert. Brachiopod and crinoid stem fossils are common in both the silty clay and the weathered chert. The weathered Fort Payne varies in thickness significantly, from 2 to $35 \mathrm{ft}$, as a result of structure.

The unweathered Fort Payne consists of a light- to medium-gray, microcryptocrystalline limestone that contains abundant bedded chert and fossils (brachiopods and crinoid stems). No solution features were observed in the Fort Payne, probably due to the relatively high silica content. Drilling in the Fort Payne proved very difficult because of hardness due to the amount of chert encountered.

\subsubsection{Mississippian Floyd Formation}

Shale within the Floyd Formation weathers to a variety of colors, with light- to medium-gray, lavendergray, reddish-gray, and yellowish-brown predominant near the surface. With depth, the color grades to a very dark grayish brown to very dark gray immediately above the unweathered zone. The weathered shale is firm and somewhat fissile, with very deformed relict bedding planes readily visible. The weathered shale zones range in thickness from 17 to $35 \mathrm{ft}$.

The limestone within the Floyd Formation weathers to a reddish-brown to reddish-yellow silty clay that is sometimes difficult to distinguish from other weathered limestones. The weathered limestone ranges in thickness from 1 to $10 \mathrm{ft}$.

Unweathered shale within the Floyd occurs as two units at the ACLR\&D site. The lower unit is comprised of a very dark gray to black, microcrystalline, very fossiliferous limestone with abundant interbedded shale. Crinoid stems, brachiopods, echinoderm fragments, and fenestrella bryozoans make 
up a majority of the fossil content. White calcite-healed fractures and slickensides are common and indicative of the significant folding and faulting that has occurred in the area. Floyd Formation limestone varies in thickness from 26 to approximately $40 \mathrm{ft}$.

The upper Floyd consists of a black, moderately hard, fissile shale. It exhibits a sub-waxy to vitreous luster and is very carbonaceous. Thin, very dark gray to black, very fine grained, siliceous, sandstone beds up to 2 in. thick are scattered throughout the shale interval. White calcite-healed fractures and very deformed bedding planes are common throughout, indicating the high degree of folding and faulting in the area.

\subsubsection{Structural Geology}

Results of the drilling indicate that the ACLR\&D site is underlain by two significant structural features. The location of these features is presented in Fig. 5.2. The oldest and most dominant is an overturned fold that trends northwest to southeast across the facility. The second feature is a strikeslip fault that trends north to south along the eastern edge of the site. Lateral displacement along the strike-slip fault is estimated at $500 \mathrm{ft}$, where the eastern block slipped to the north relative to the western block.

Cross section A - $\mathrm{A}^{\prime}$ from $\mathrm{CH} 78$ to $\mathrm{CH} 81$ illustrates a conceptualized diagram of the overturned fold as determined from the available data (Fig. 5.3). The inferred axis of the fold strikes approximately $\mathrm{N} 45 \mathrm{~W}$ and plunges southeast up to $30^{\circ}$. Lithologic information from $\mathrm{CH} 87$ and field reconnaissance northwest of the site suggest that the fold continues to the northwest, possibly for several miles. To the southeast, the fold is offset to the north where it is breached by the strike-slip fault. Weathered remnants of overturned bedding are observed in $\mathrm{CH} 36$ (Fig. 5.4) and further east on the E.C. Gaston Steam Plant property, suggesting that the fold continues to the east or southeast. However, there is not enough data to plot the inferred location of the fold axis east of the strike-slip fault.

Cross section B - B' from CH81 to $\mathrm{CH} 36$ (Fig. 5.4) illustrates formation relationships on opposite sides of the strike-slip fault. In addition to the main fault, a small area of faulting has occurred between CH83 and CH55. It appears that a large piece of Frog Mountain Sandstone was sheared off during movement on the strike-slip fault and wedged in its current position as shown in Fig. 5.4. Evidence of this secondary faulting is found in the extensive fault gouge material observed during the drilling of nearby monitoring wells (MW35 and MW37).

The combined effects of faulting, folding, and weathering of the various rock types have produced a bedrock surface that dips gently to the northeast (Fig. 5.5). The bedrock surface contour map depicts several low spots that represent the areas where carbonate rocks have been dissolved. These low areas are significant in that they represent conduits for potential contaminant migration from the weathered residuum into the bedrock groundwater system.

\subsubsection{Hydrogeology}

Discussion of the hydrogeology is divided into hydrostratigraphy, groundwater flow directions, and hydraulic characteristics. 

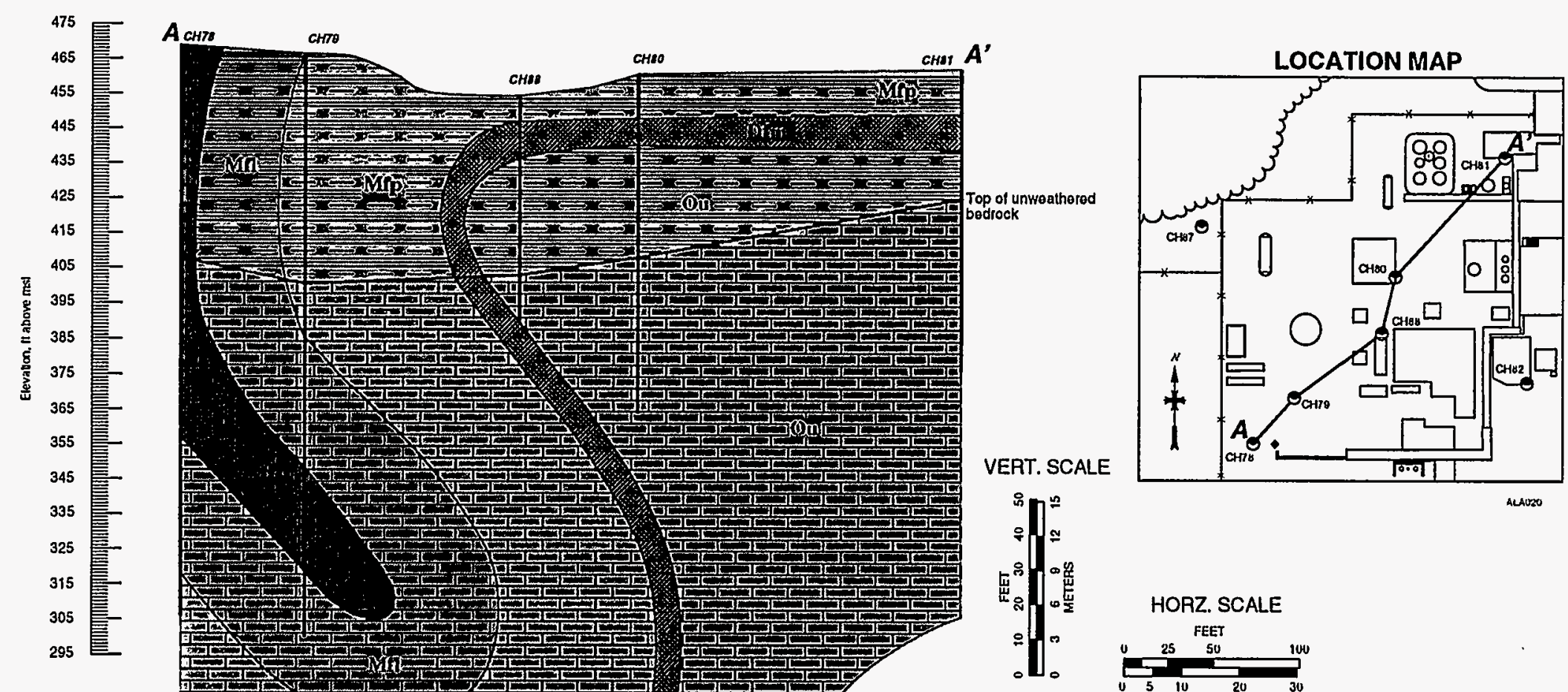

ALAODO
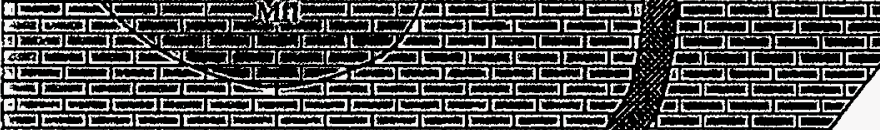

Mis Floyd Shale

$\square$ Mn Foyd Limosione

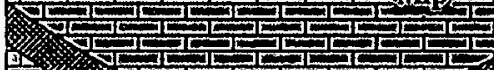

Mep For Payno Limestona

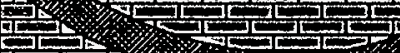

DIm Frog Mountain Sandstone

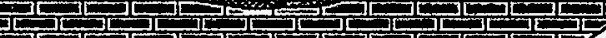

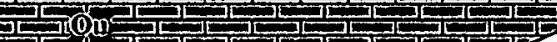

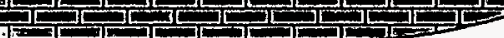

Ou Ordovician Carbonales (Undillorontialed)

Fig. 5.3. Cross section $A-A^{\prime}$ illustrating the overturned fold. 


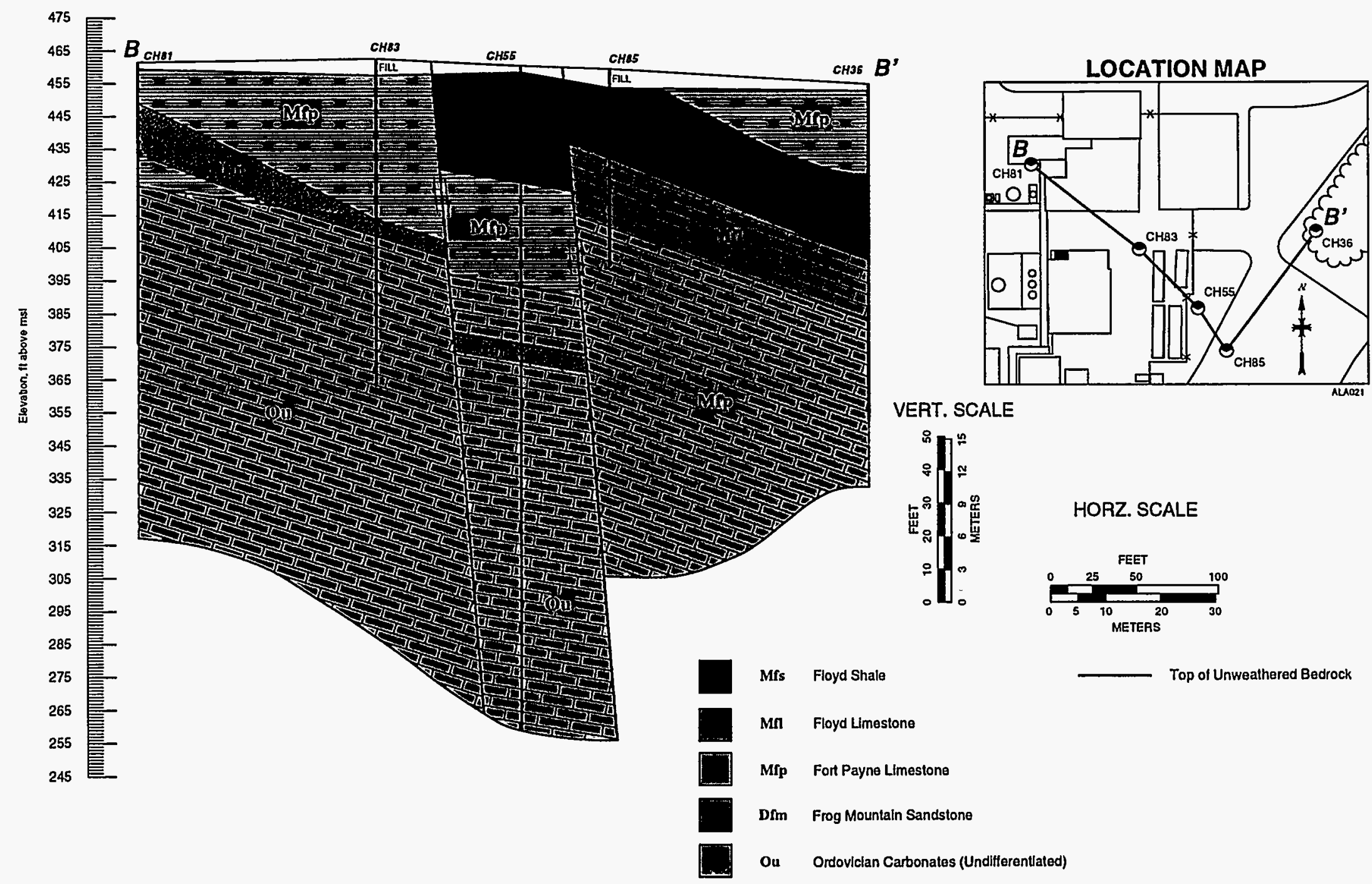

Fig. 5.4. Cross section $B-B^{\prime}$ illustrating the strike-slip fault. 


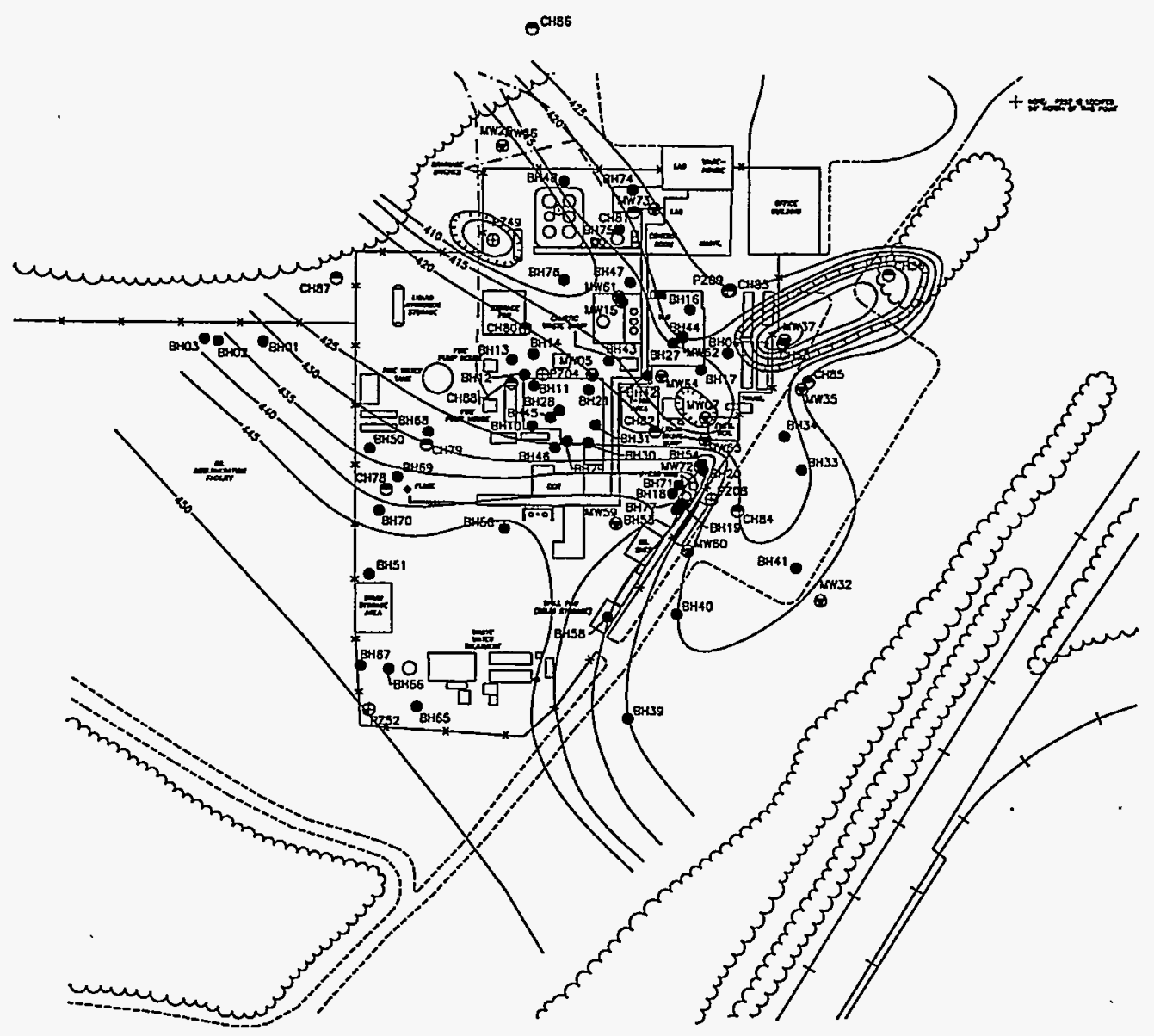

Southern Clean Fuels

Wilsonville, Alabama
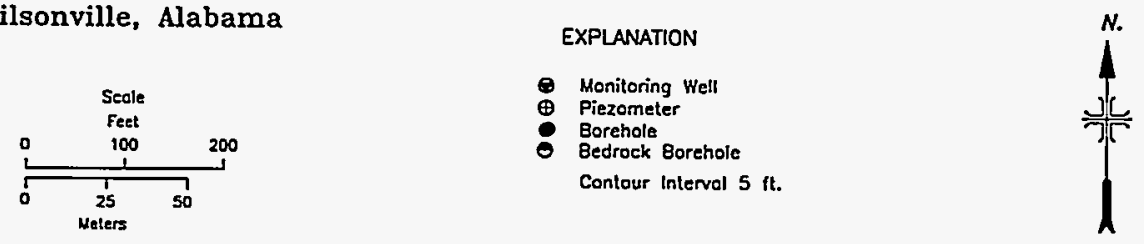

Rev nitpos/9s

Fig. 5.5. Bedrock contour map. 


\subsubsection{Hydrostratigraphy}

As previously discussed, the ACLR\&D site is characterized by an overturned fold and strike-slip fault associated with the Coosa deformed belt. A weathered residuum overlying the bedrock further complicates the site hydrogeology. Delineating the site hydrogeology into continuous aquifers in order to understand groundwater flow directions and rates involves an additional level of analysis. For example, in regions dominated by continuous layered geology, permeable zones can be identified and monitored at discrete levels. This is not possible at the ACLR\&D site, where permeable units may be discontinuous due to faults or folds or may be weathered into lower permeability residuum where exposed to the surface. Consequently, the water-bearing capacity of the geologic units and their continuity and locations with regard to observed groundwater flow directions must all be considered in determining a geologic unit's ability to be an important pathway for contaminant migration.

In general terms, the hydrostratigraphy at the ACLR\&D site can be divided into two zones: a lowpermeability residuum and an intact bedrock unit. The residuum consists of fine-grained material that exhibits relict bedding characteristics and very low permeability. Consequently, the emphasis of this section will be placed on the bedrock hydrology. The lithology and structure of the bedrock and its relationship to groundwater migration will be discussed in detail.

One of the initial assumptions of the hydrogeologic investigation at the site was that it was essential to determine the location of carbonate units that could exhibit karst features and subsequently act as pathways for contaminant migration. Sinkhole activity due to karst limestones has been previously identified in the region. As noted on the cross sections (Figs. 5.3 and 5.4), limestones were identified throughout the bedrock underlying the facility.

\subsubsection{Groundwater Flow Directions}

\section{Residuum}

The potentiometric map for the residuum based on April 1993 water-level data is presented in Fig. 5.6. Although the general flow direction is east to northeast and follows the topography in the area (which slopes towards the Coosa River), groundwater flow in the residuum is influenced by several local factors. Primarily, groundwater flow in the less-permeable clays of the residuum is controlled by bedrock topography and consistently seeks the lowest areas. Therefore, the most obvious direction of groundwater movement is toward the lowest point in the bedrock near MW37 in Fig. 5.5. The less-permeable clays overlying the topographic lows in Fig. 5.5 have less-measurable effects on groundwater flow due to their limited capacity to transmit water to the bedrock system. The groundwater mound observed under MW62 (Fig. 5.6) coincides with the thermal liquefaction unit (TLU) area, which was the oldest process facility, and probably results from leaking utilities in the area creating an artificially high water table (Charles Cantrell, SCF, personal communication with Frank Gardner, ORNL/GJ, October 10, 1992). Additional evidence of leaking utilities was noted by field personnel during drilling activities, where saturated sediments were observed from immediately below the ground surface to the bedrock. Other suspected sources of artificial water in the residunm are the waste sump south of the TLU and the caustic waste sump within the TLU. Residuum water levels are further complicated by the heterogeneity of the residuum itself: The combinations of low-permeability clays, chert, and weathered sandstone within the residuum aquifer along with the artificial water sources can yield misleading 


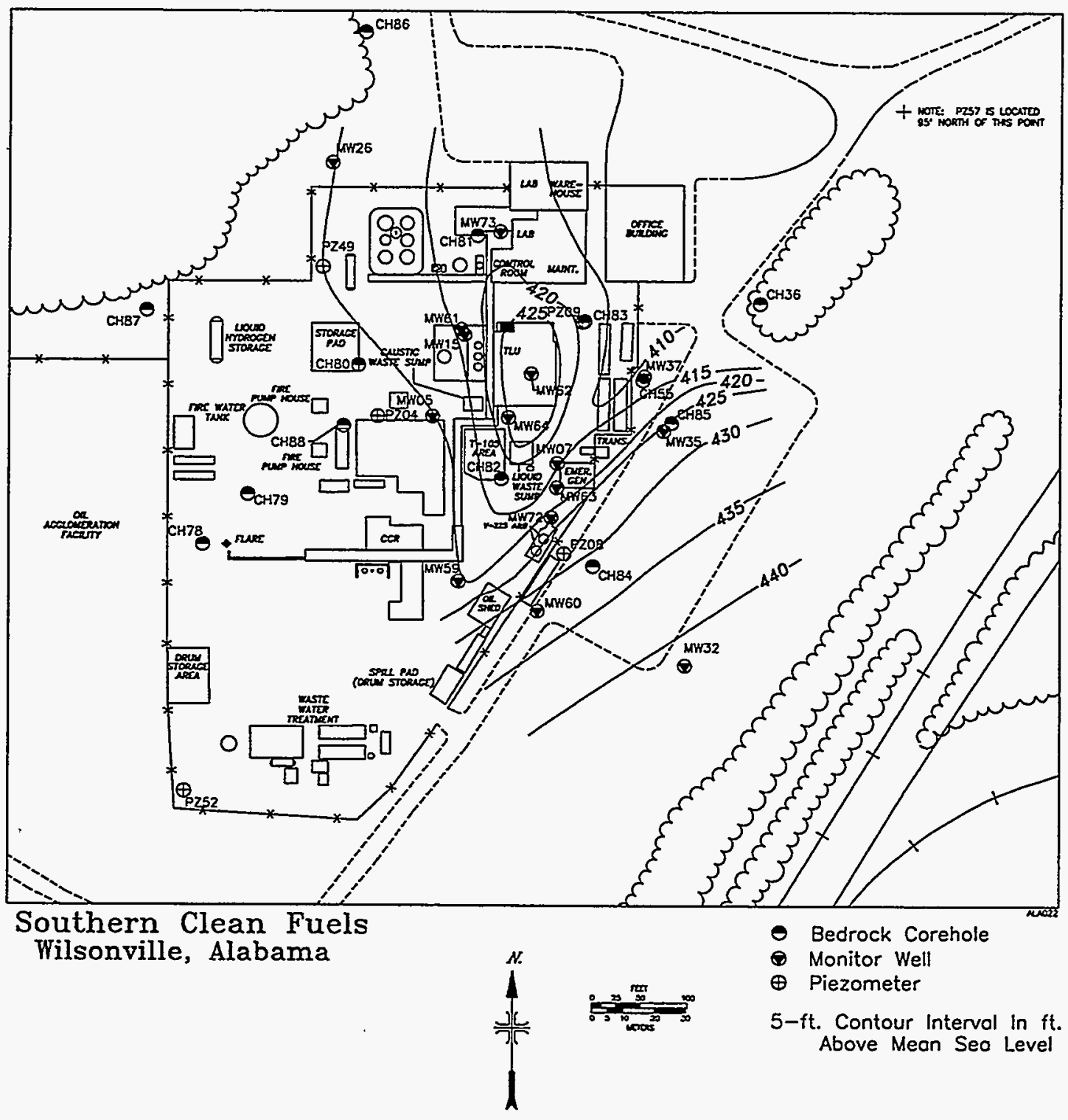

Fig. 5.6. April 1993 residuum potentiometric map. 
water-level information. Finally, the fault along the eastern property boundary appears to have an influence on groundwater flow by presenting a more-permeable path for residuum water to reach the bedrock aquifer system. Consequently, additional water levels were obtained and more potentiometric maps were updated as part of the RI.

\section{Bedrock}

Groundwater flow directions in the bedrock are controlled by the hydraulic gradient and the geologic structure of the permeable units. The hydrogeology of the bedrock is characterized by water movement along fractures that may be enhanced by solution. The complex structure of the bedrock, as discussed in the structural geology section, has yielded an equally complex fracture pattern. Regional tectonics along with local folding, thrusting, and faulting have resulted in a wide distribution of fractures.

The key to groundwater flow in a fractured aquifer is understanding the degree of interconnection of the fractures. One method is to compare the water-level measurements from wells completed in different fracture zones in the bedrock. Figure 5.7 presents the potentiometric map for the bedrock aquifer, which suggests that the bedrock fractures are interconnected and transmitting water toward the Coosa River. Water-level data from CH81 were not used due to the presence of leaking utilities in the area. The interconnection of the fractures is important from a contaminant-transport point of view. If contaminants enter a selected set of fractures, then a downgradient well completed in a separate set of fractures that are hydraulically isolated may not detect the contamination.

\subsubsection{Hydraulic Characteristics}

\section{Residuum}

The permeability of the residuum underlying the site can be characterized as less-permeable sediments due to the fine-grain texture. Table 5.1 shows the results of single-well tests conducted on selected wells. Water levels in most of the residuum wells recover at such slow rates that it is impossible to conduct reliable permeability tests. Consequently, the hydraulic conductivity values presented in Table 5.1 represent maximum values for the residuum. These values range from those typical of a silt unit to those of a clay unit and yield an average hydraulic conductivity of less than $10^{-1} \mathrm{ft} / \mathrm{d}$.

Table 5.1. Results of single-well pumping tests

\begin{tabular}{|c|c|c|}
\hline Well Number & Test Number & Hydraulic Conductivity, ft/d \\
\hline \hline MW15 & 1 & $3.37 \times 10^{-2}$ \\
& 2 & $3.93 \times 10^{-2}$ \\
\hline MW26 & 1 & $1.21 \times 10^{-4}$ \\
\hline MW07 & 1 & $3.89 \times 10^{-1}$ \\
\hline
\end{tabular}




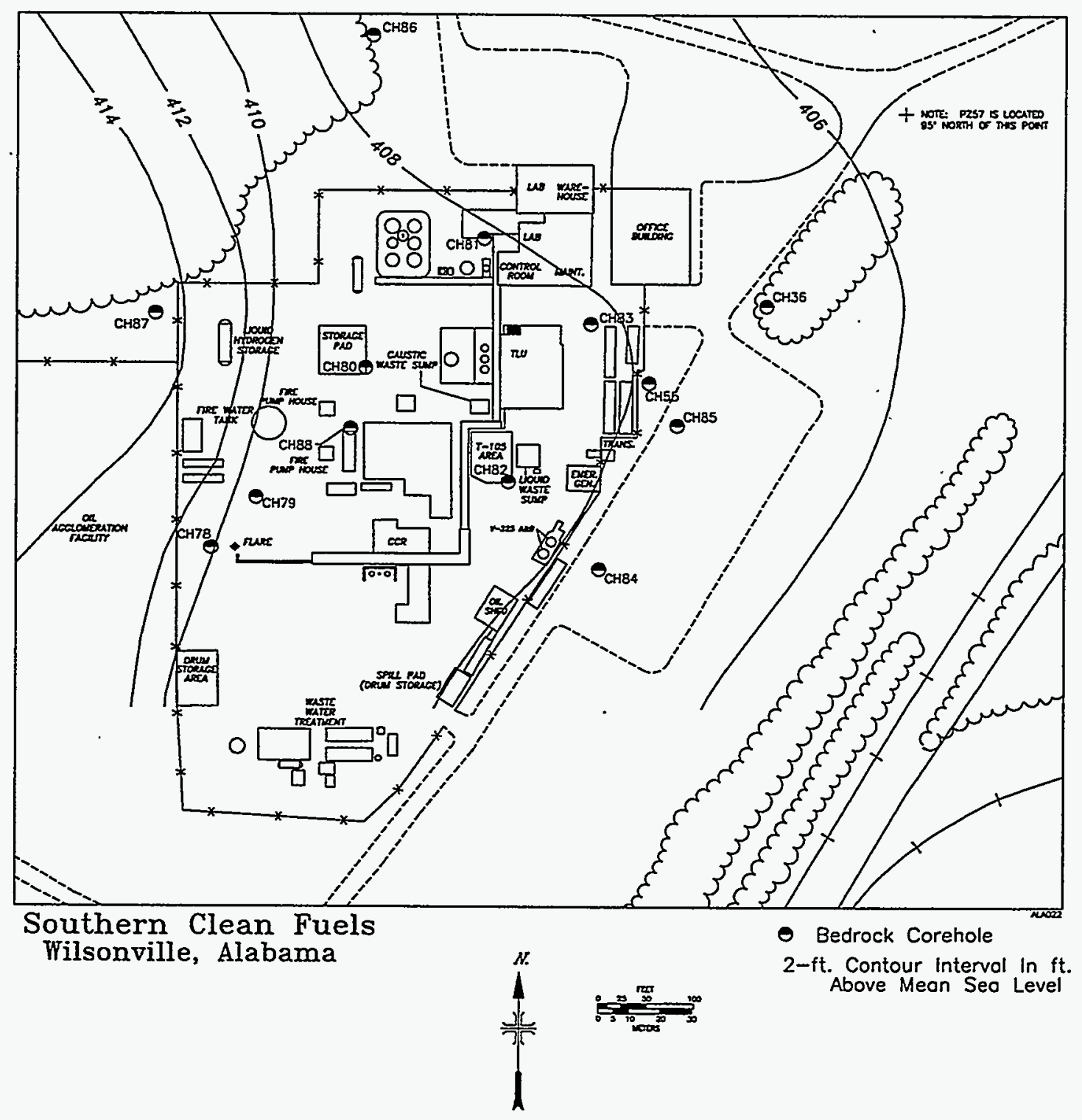

Fig. 5.7. May 1993 bedrock potentiometric map. 


\section{Bedrock}

In order to characterize the permeability of the bedrock, fractures were logged by core drilling, and selected coreholes were packer-tested. It was not possible to packer-test every corehole because several holes were blocked by rock debris from fractured zones. Consequently, fractures located during the drilling either by circulation loss or fractured core are listed in Table 5.2. The Frog Mountain Formation is fractured wherever it is encountered as competent rock. Composed of brittle quartzite, the Frog Mountain has fractured due to the intense folding and faulting in the area. Undifferentiated Ordovician limestones were also found to be fractured, with solution enhancement in several coreholes. With the exception of $\mathrm{CH} 80$, all of the water-producing fractures in limestone were located near the bedrock/residuum contact. This is the result of small fractures located near the recharge source that were enhanced by solution. With depth, many of these fractures are filled with calcite and become impermeable. CH80, on the other hand, contains a fracture below the bedrock/residuum contact that is associated with a fold. The Fort Payne Formation appears to be less fractured than the other formations. In CH55, the observed fractures are associated with extensive fractures in the Frog Mountain. In CH85, limited cavities in the Fort Payne are associated with extensive cavities in the overlying limestone of the Floyd Shale.

Table 5.2 Fracture locations in bedrock coreholes

\begin{tabular}{|c|c|c|l||}
\hline Corehole & Interval, ft bgs & Geologic unit & \multicolumn{1}{|c|}{ Comments } \\
\hline CH55 & 80.0 to 83.0 & Mfp & Near Dfm contact \\
\hline CH55 & 87.5 to 89.5 & Dfm & $\begin{array}{l}\text { Major fracture, } \\
\text { circulation lost }\end{array}$ \\
\hline CH80 & 95.0 to 96.0 & Ou & Other fractures present \\
\hline CH82 & 51.4 to 51.8 & Ou & Near residuum contact \\
\hline CH83 & 51.7 to 55.0 & Dfm & Near residuum contact \\
\hline CH84 & 46.0 to 53.0 & Dfm & Collapsed into hole \\
\hline CH85 & 28.0 to 53.0 & MfMfp & Several large cavities \\
\hline CH86 & 49.0 to 58.0 & Ou or Mfp (?) & Several large cavities \\
\hline CH88 & 51.0 to 61.0 & Ou & Several large cavities \\
\hline
\end{tabular}

Mfp = Mississippian Fort Payne Limestone

Dfm = Devonian Frog Mountain Sandstone

Ou $=$ Ordovician undifferentiated carbonates

Mf = Mississippian Floyd Limestone

$\mathrm{ft}$ bgs $=$ feet below ground surface 
Packer tests were conducted on several coreholes to determine the bedrock permeability (Table 5.3). The bedrock is not fractured throughout the entire section, as indicated by the large number of zones that exhibited no measurable permeability. The packer tests also suggest that water movement in the bedrock is isolated to scattered fractures that are capable of producing substantial quantities of water. On a general scale, the Frog Mountain exhibits significant fracture permeability where present in the bedrock. The undifferentiated Ordovician limestones show scattered permeable fractures, with large sections of impermeable rock. The Fort Payne is generally impermeable or exhibits a low permeability, as found in CH55. Although the Floyd Limestone was not tested, the absence of fractures observed in cores from $\mathrm{CH} 36, \mathrm{CH} 55$, and $\mathrm{CH} 79$ suggests that this unit generally exhibits low permeability. The only exception to this condition was observed in the severe solutioning of the Floyd Limestone in CH85, where mud-filled cavities were observed during drilling. Upon removal of the coring equipment, the corehole collapsed, preventing any packer tests at this location.

Table 5.3 Packer test results for bedrock coreholes

\begin{tabular}{||c|c|c|c||}
\hline Corehole & Interval tested, ft bgs & Geologic unit & Hydraulic K, ft/d \\
\hline \hline CH36 & 57.0 to 102.0 & Mfp & 0 \\
\hline CH55 & 79.8 to 102.0 & Mfp, Dfm, Ou & $*$ \\
& 71.0 to 81.0 & Mfp & 1.7 \\
& 66.0 to 76.0 & Mfp & 6.5 \\
\hline CH80 & 87.0 to 96.7 & Ou & $*$ \\
\hline CH81 & 77.0 to 85.7 & Ou & 0 \\
& 67.0 to 85.7 & Ou & 0 \\
& 57.7 to 85.7 & Ou & 0 \\
& 47.7 to 85.7 & Ou & 0 \\
& 37.0 to 85.7 & Ou & 0 \\
CH82 & 81.7 to 91.7 & Ou & 0 \\
& 71.7 to 91.7 & Ou & 0 \\
& 61.7 to 91.7 & Ou & 0 \\
& 51.7 to 91.7 & Ou & Ou \\
\hline CH86 & 48.0 to 91.7 & Ou or Mfp (?) & $*$ \\
\hline
\end{tabular}

* $\quad=$ Permeability exceds the maximum value measurable.

Mfp = Mississippian Fort Payne Limestone

Dfm = Devonian Frog Mountain Sandstone

$\mathrm{Ou}=$ Ordovician undifferentiated carbonates

$\mathrm{ft}$ bgs $=$ feet below ground surface 


\subsection{Discussion}

The hydrogeologic model presented in the previous sections indicates that the residuum (surface soils) exhibits low permeability. Furthermore, low hydraulic conductivities suggest little potential for significant lateral contamination migration. Indeed, once water is removed from these formations, water-level recovery time is slow (hours to days). The total amount of water that can be removed is so small that any attempt for beneficial use of this water is precluded. Hence, on-going characterization work should focus on the more permeable bedrock.

The geologic investigation revealed complex structural features in the bedrock underlying the ACLR\&D facility. The bedrock is made up of limestone that contains numerous solution cavities (indicated by the large cavities in coreholes, Table 5.2). The karst nature of the bedrock and the highly faulted structure are particularly conducive to contaminant migration. However, based on the available hydrologic data (regional and site-specific), the two Wilsonville municipal water-supply wells, which are approximately 1.5 miles southwest of the ACLR\&D site, are upgradient of the ACLR\&D site and are thus safe from potential contamination. Furthermore, access to the ACLR\&D site is restricted, and its proximity to the E.C. Gaston Steam Plant precludes anything other than industrial use.

\section{CONCLUSION}

The hydrogeologic assessment, although complicated by the unusual structural complexity of the subsurface, nevertheless provided valuable information about potential contaminant migration at the site. In summary, the potential receptors and migration characteristics brought to light by the hydrogeologic investigation allow these conclusions: 1) the location and present conditions of the site provide significant safety with regard to the potential exposure to humans and the environment; 2) potential groundwater contamination in the residuum is not a threat to the environment; and 3) groundwater in the limestone aquifers is not flowing toward potential receptors. 


\section{REFERENCES}

APCO. 1991. Southern Clean Fuels Wilsonville, Alabama Environmental Assessment Phase II Report (draft). Alabama Power Company.

Miller, Richard D., D. W. Steeples, J. A. Anderson, D. D. Dettmann, Jianghai Xia, C. B. Park, and L. C. Musson. 1993. Shallow Seismic Reflection Survey at the Southern Clean Fuels Coal Liquefaction Facility near Wilsonville, Alabama. University of Kansas, Lawrence, Kansas.

ORNL. 1993. Environmental Technology Section (Formerly Pollutant Assessments Group)

Procedures Manual. ORNL-6645/V2/R2. Oak Ridge National Laboratory, Grand Junction, Colorado.

Planert, M., and J. L. Pritchett, Jr. 1989. Geohydrology and Susceptibility of Major Aquifers to Surface Contamination in Alabama; Area 4. Water-Resources Investigations Report 884133. U.S. Geological Survey.

SCS. 1991. Operation of the Advanced Coal Liquefaction Research \& Development Facility at Wilsonville. Southern Company Services, Birmingham, Alabama.

Thomas, W.A., and J. A. Drahovzal, eds. 1974. The Coosa Deformed Belt in the Alabama Appalachians. Alabama Geological Society Guide book for the 12th Annual Field Trip. 


\section{APPENDIX}

MONITORING WELL, BEDROCK WELL, PIEZOMETER, AND SOIL BORING LOGS 


\section{MONITORING WELL, BEDROCK WELL, PIEZOMETER, AND SOIL BORING LOGS}

This appendix is divided into four sections:

$\begin{array}{ll}\text { Section 1: } & \text { Monitoring Well Logs } \\ \text { Section 2: } & \text { Bedrock Well Logs } \\ \text { Section 3: } & \text { Piezometer Logs } \\ \text { Section 4: } & \text { Soil Boring logs }\end{array}$


Monitoring Well Logs 
Orn 1 OAK RIDGE NATIONAL LABORATORY

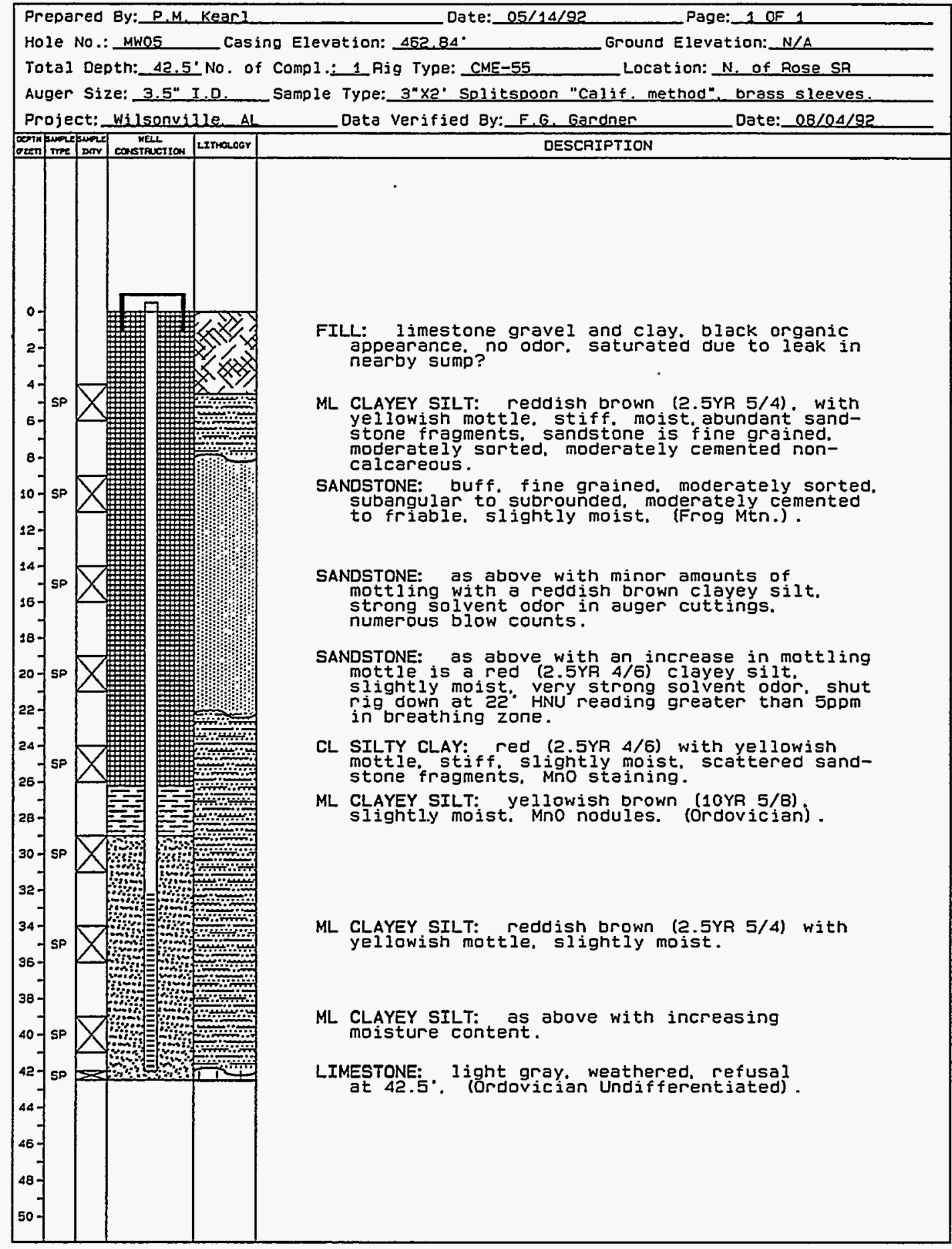


OTI 1 Oak RidGe national LaboRatory

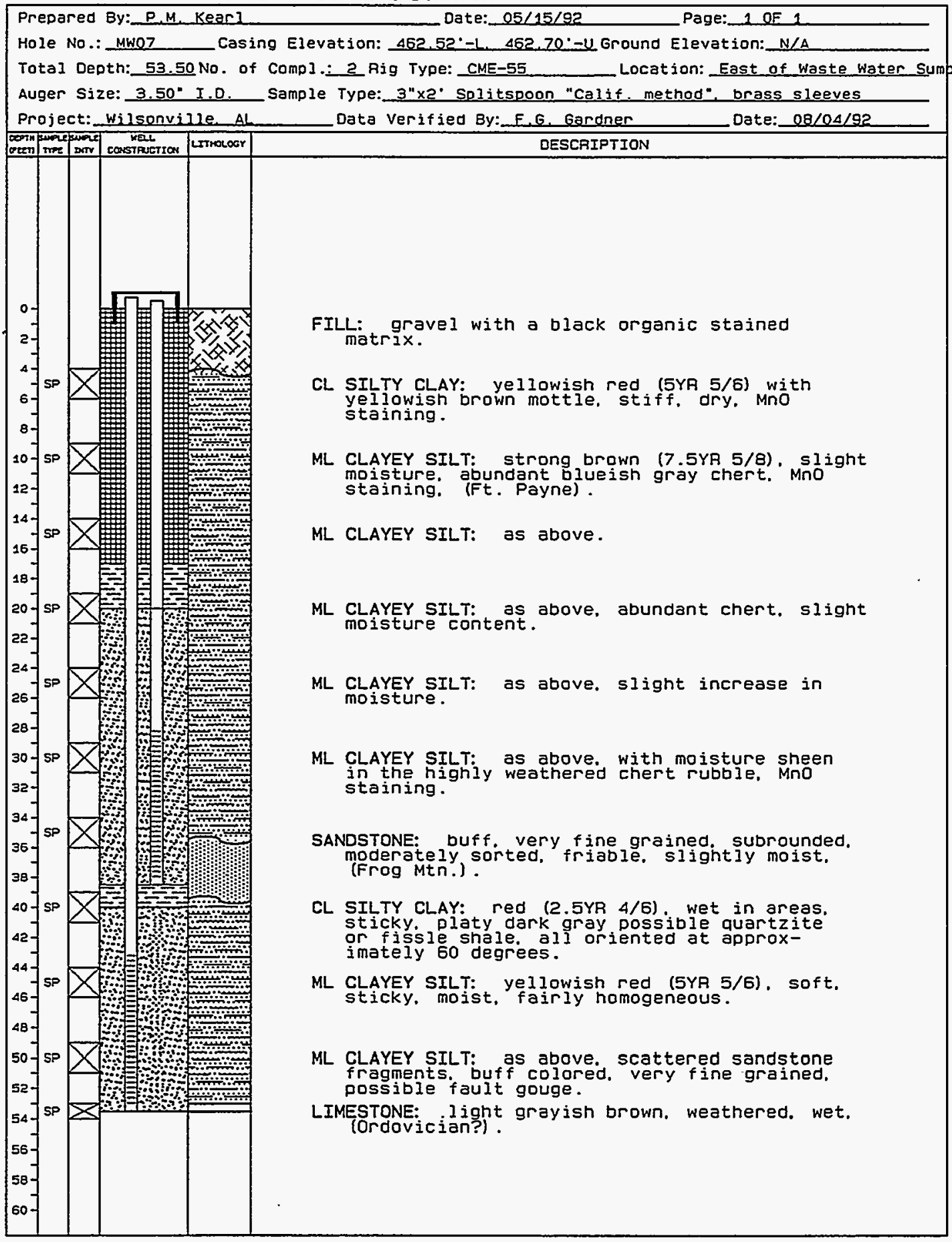


OTII OAK RIDGE NATIONAL LABORATORY

Well Summary Information

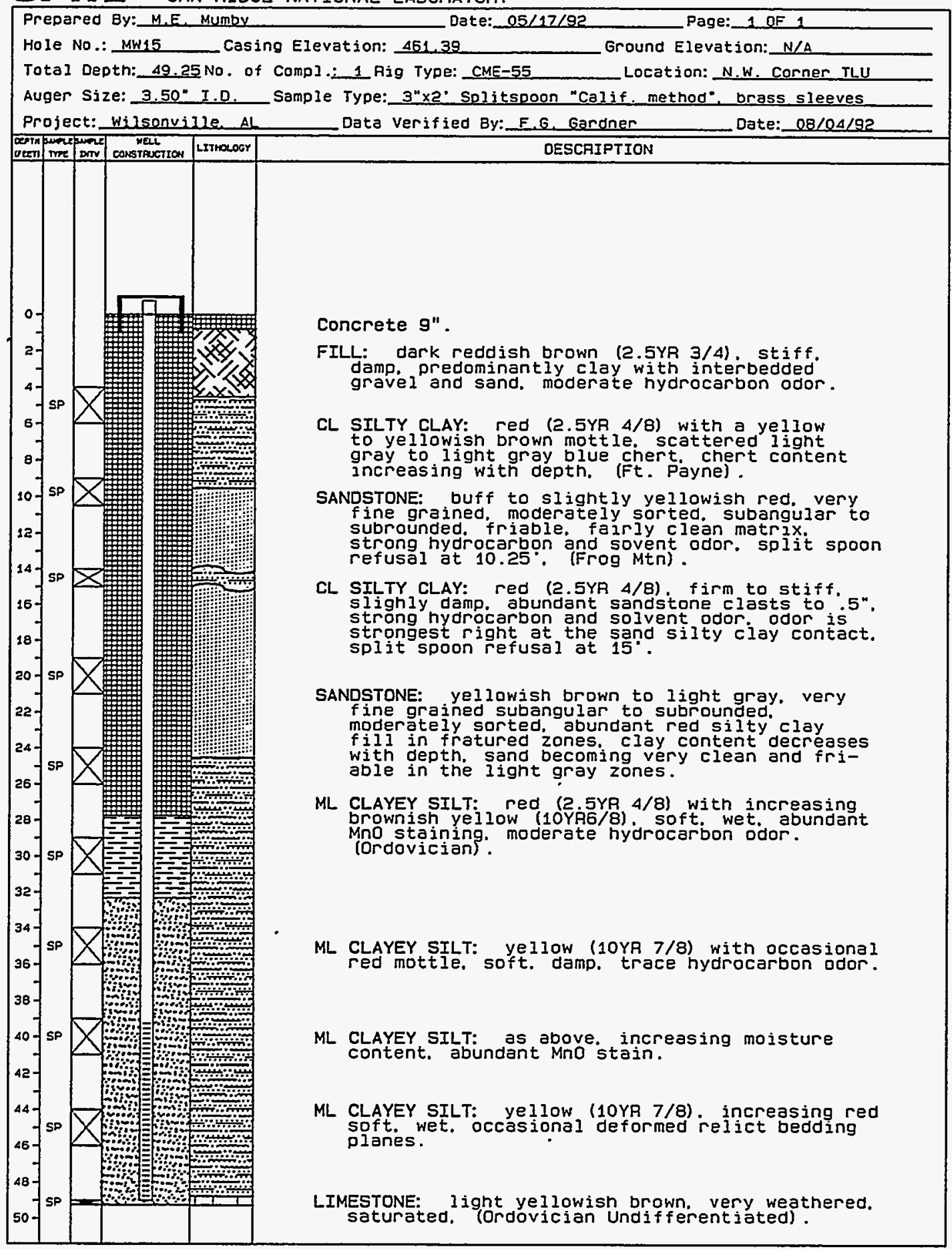


QIII OAK RIDGE NATIONAL LABORATORY

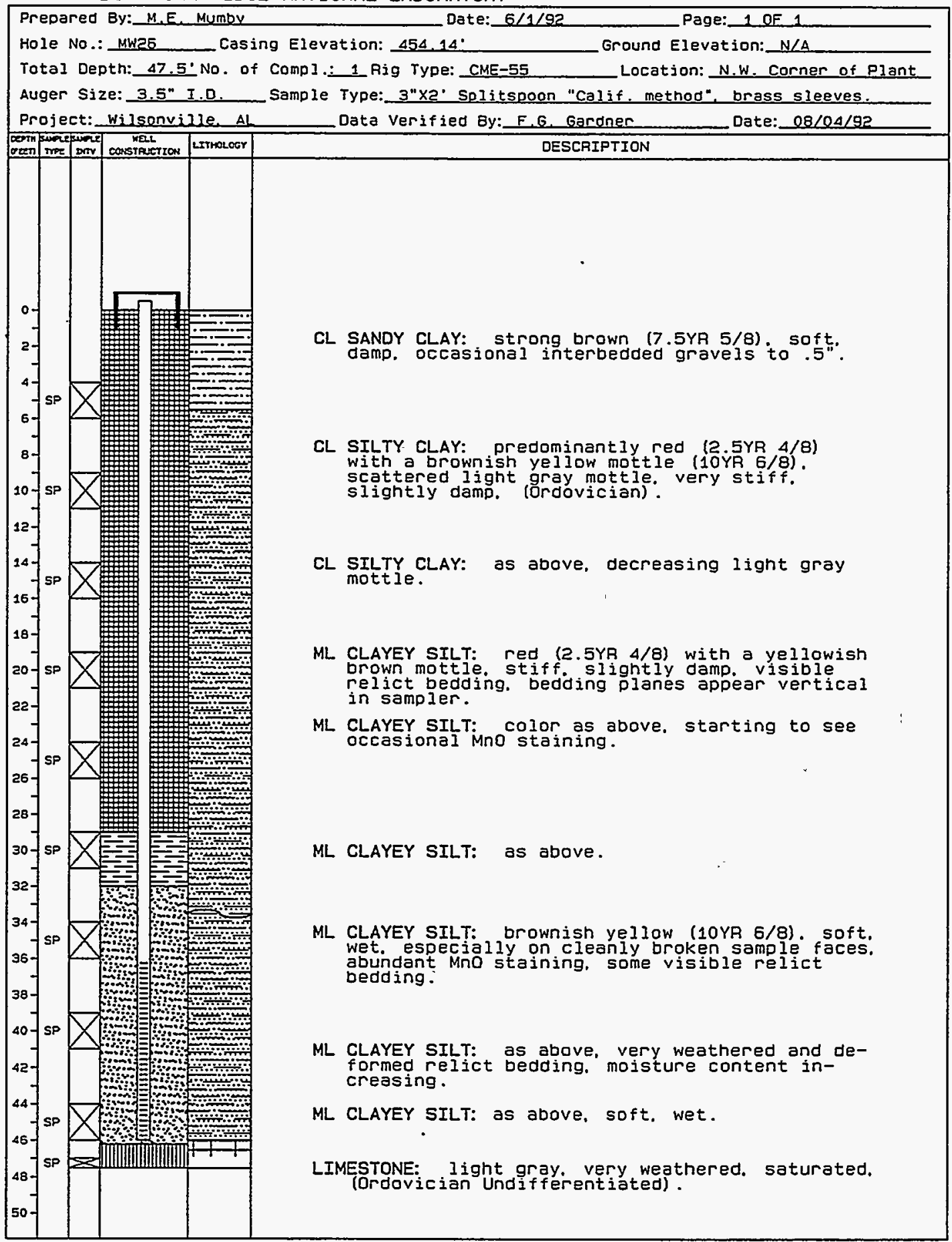


OrII OAK RIDGE NATIONAL LABORATORY

Well Summary Information

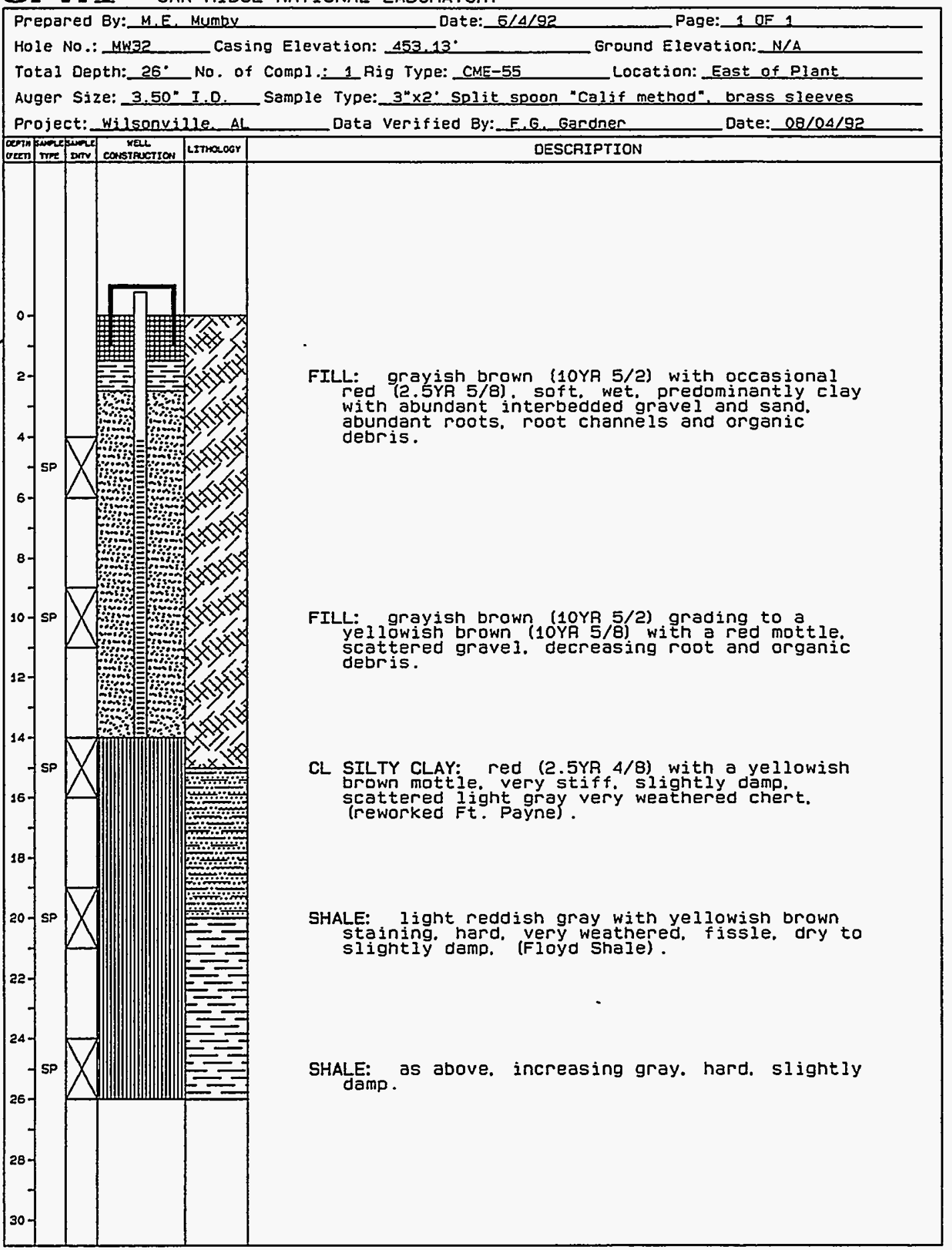


Well Summary Information

QIII OAK RIDGE NATIONAL LABORATORY

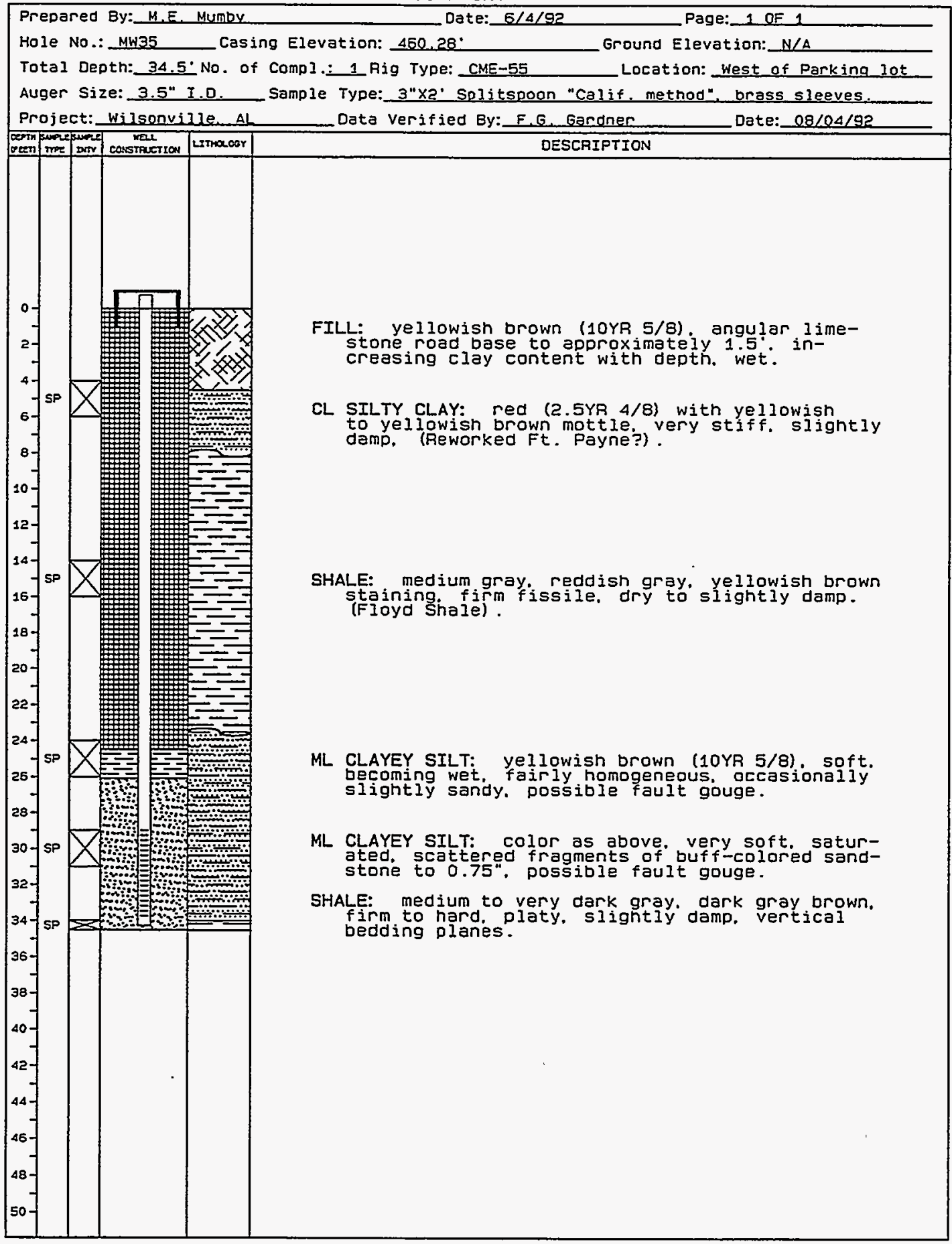


orn 1

Well Summary Information

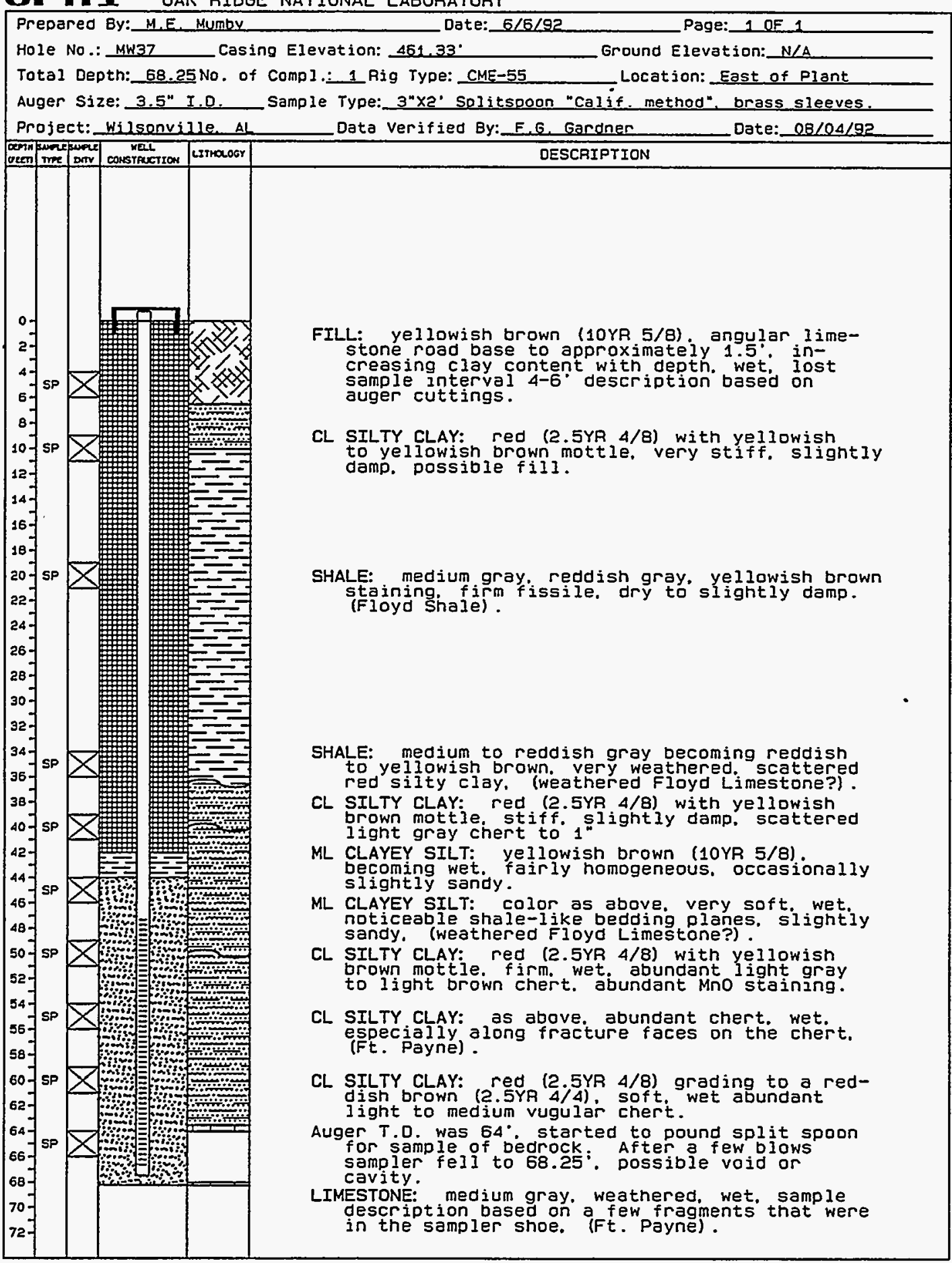


orn 1 oak ridge national LABORATORY

Well Summary Information

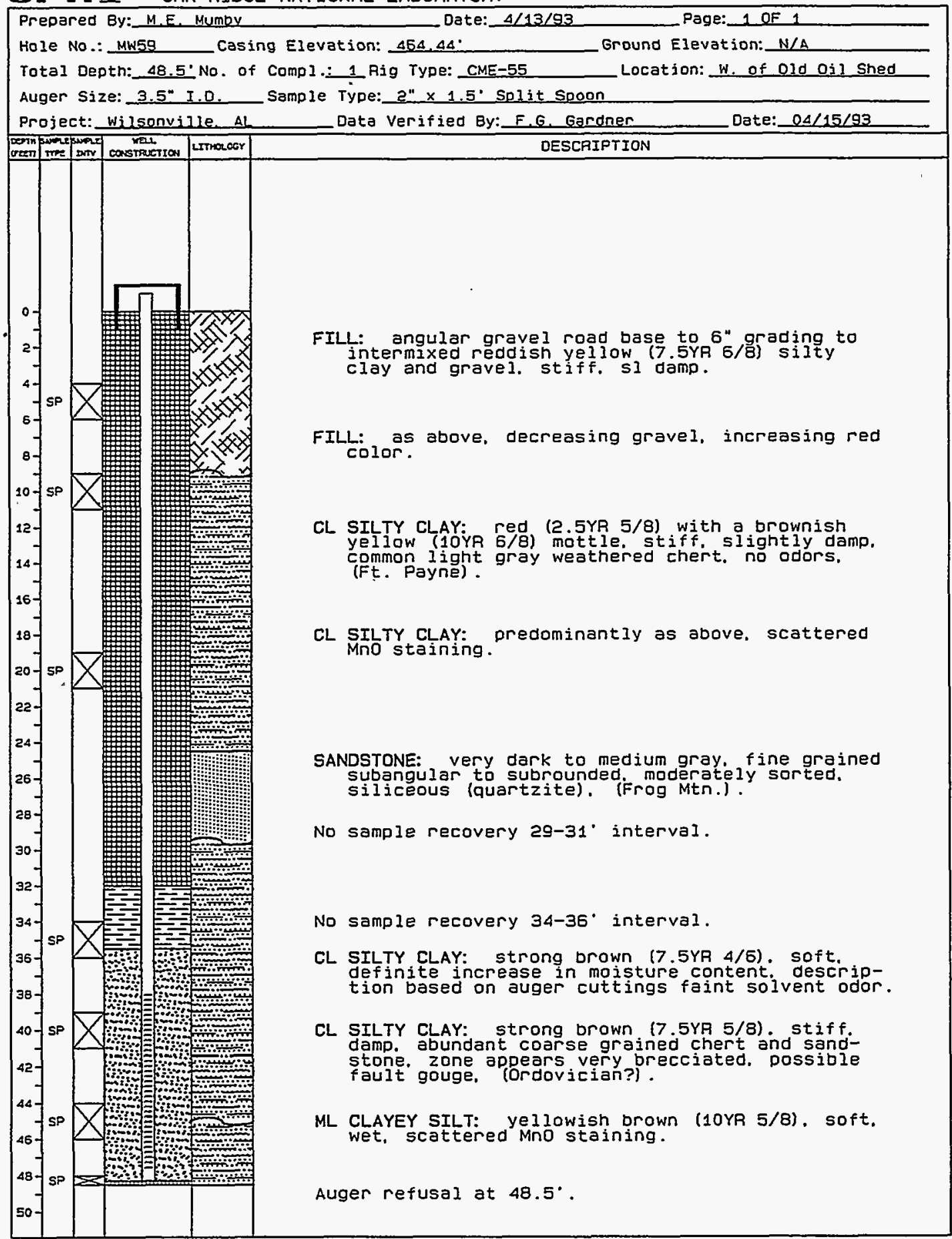


$\operatorname{orn} 1$

Well Summary Information

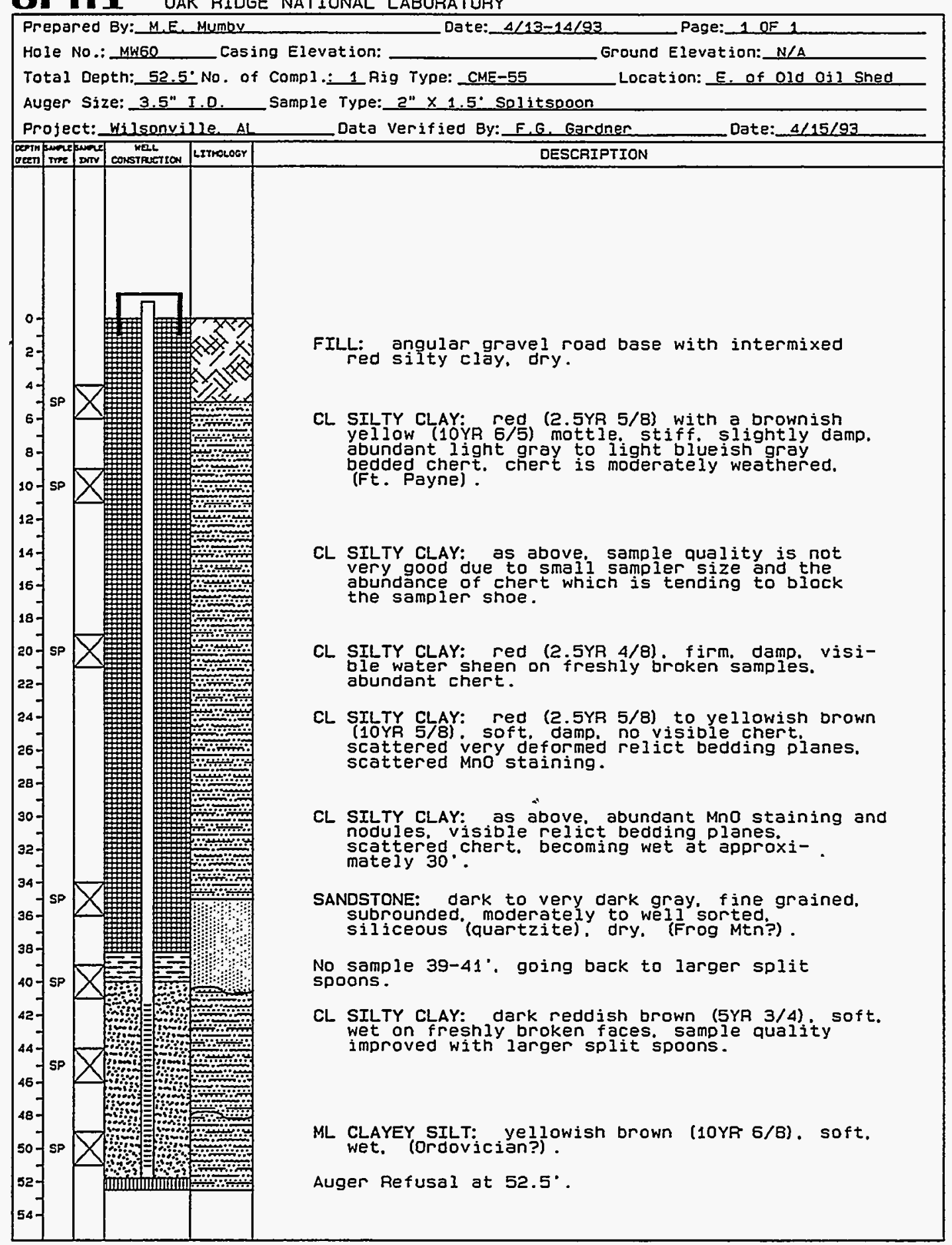


QII OAK RIDGE National Laboratory

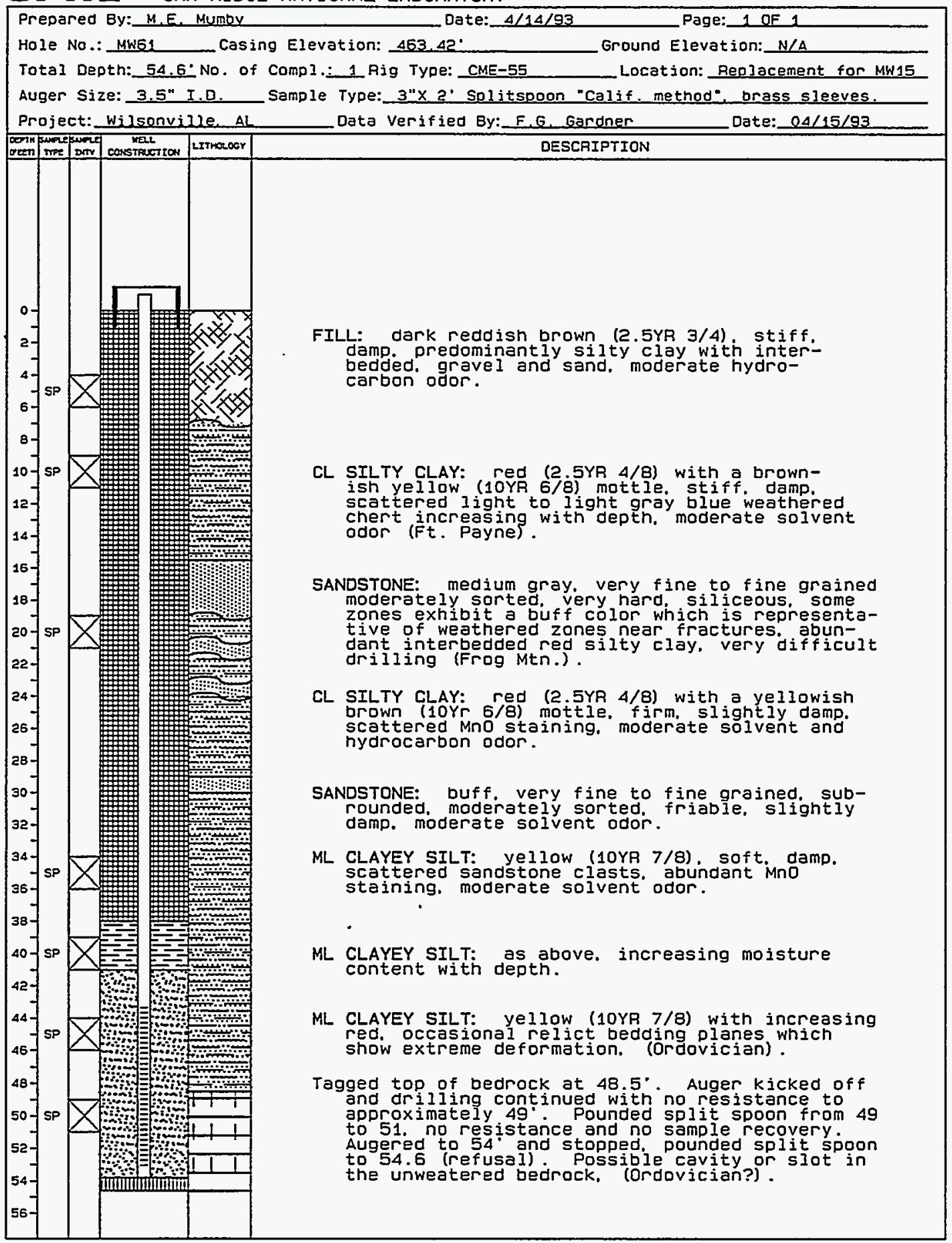


QTII OAK RIDGe national LaboRatory

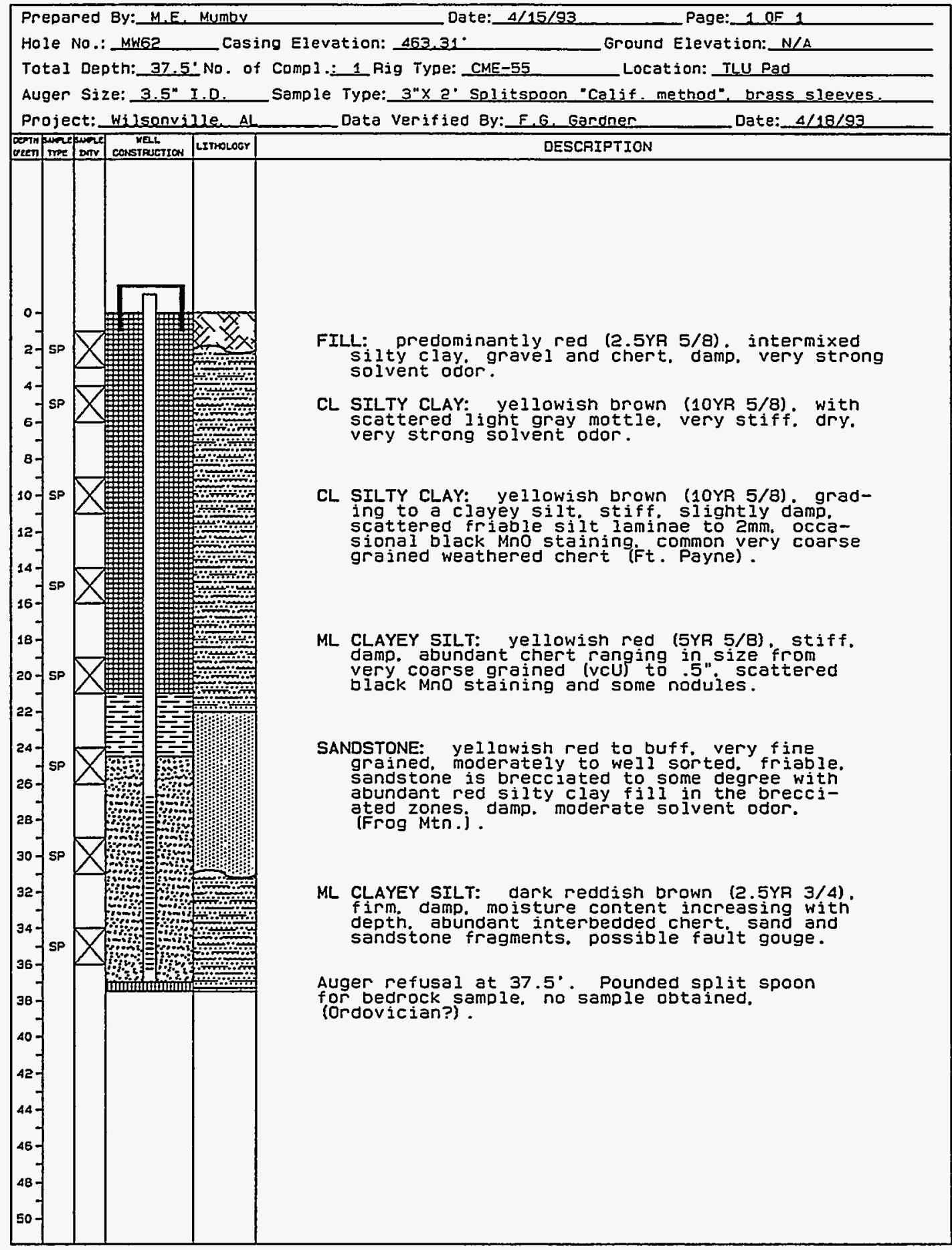


Orn 1 OAK RIDGe NATIONAL LABORATORY

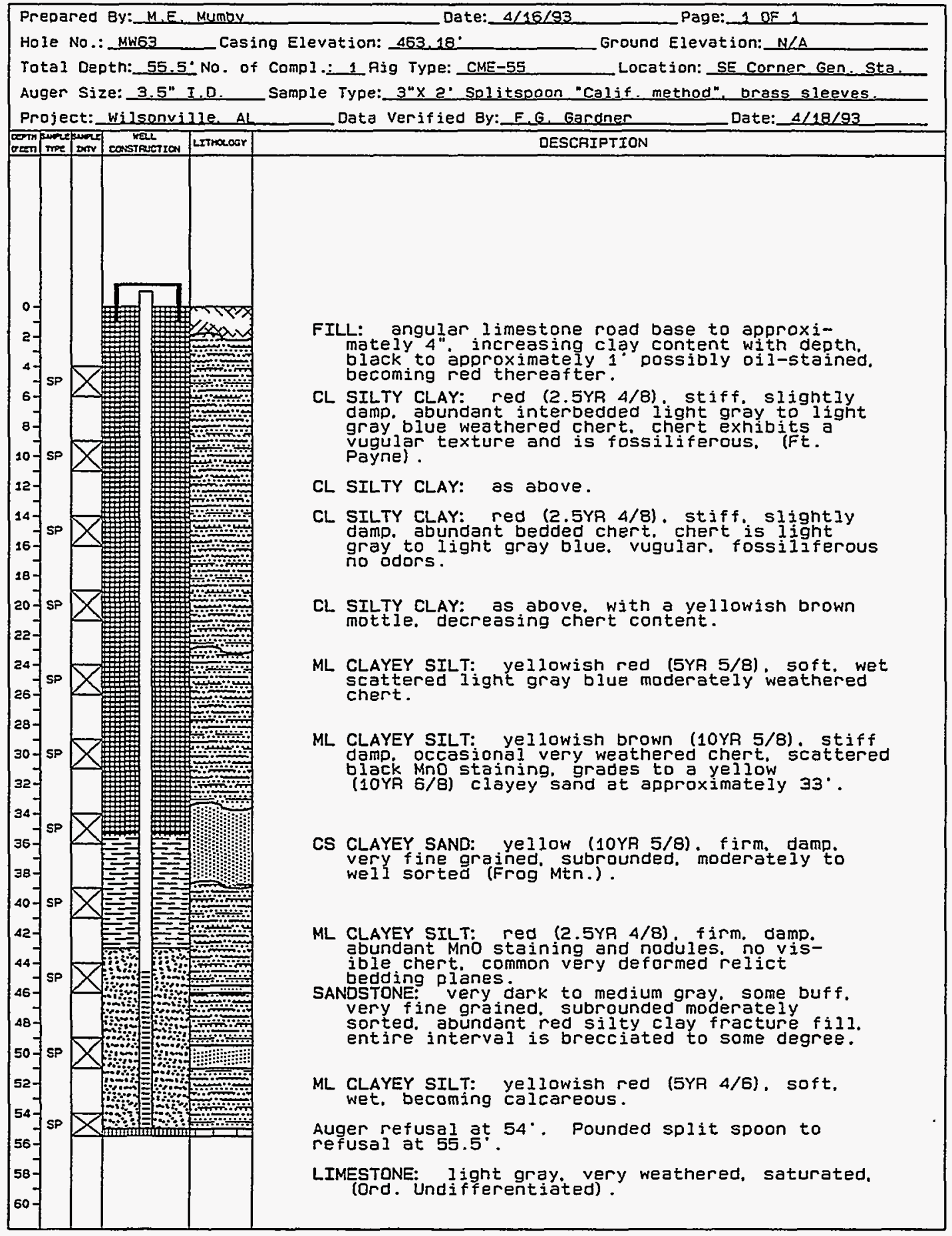


OrIn 1 Wak RIDGe natIONAL LaboRatoRY

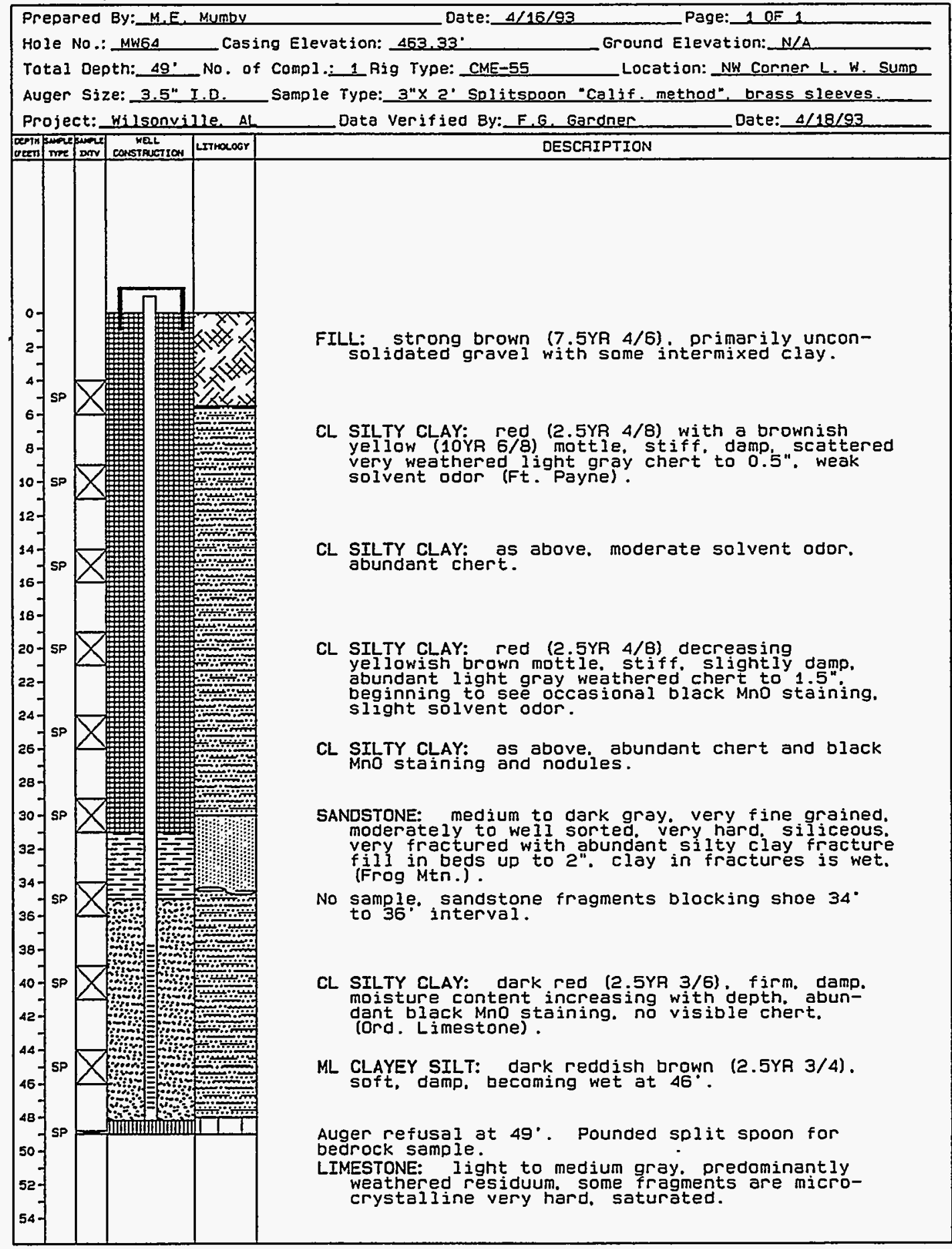


orn1

We I Summary Information

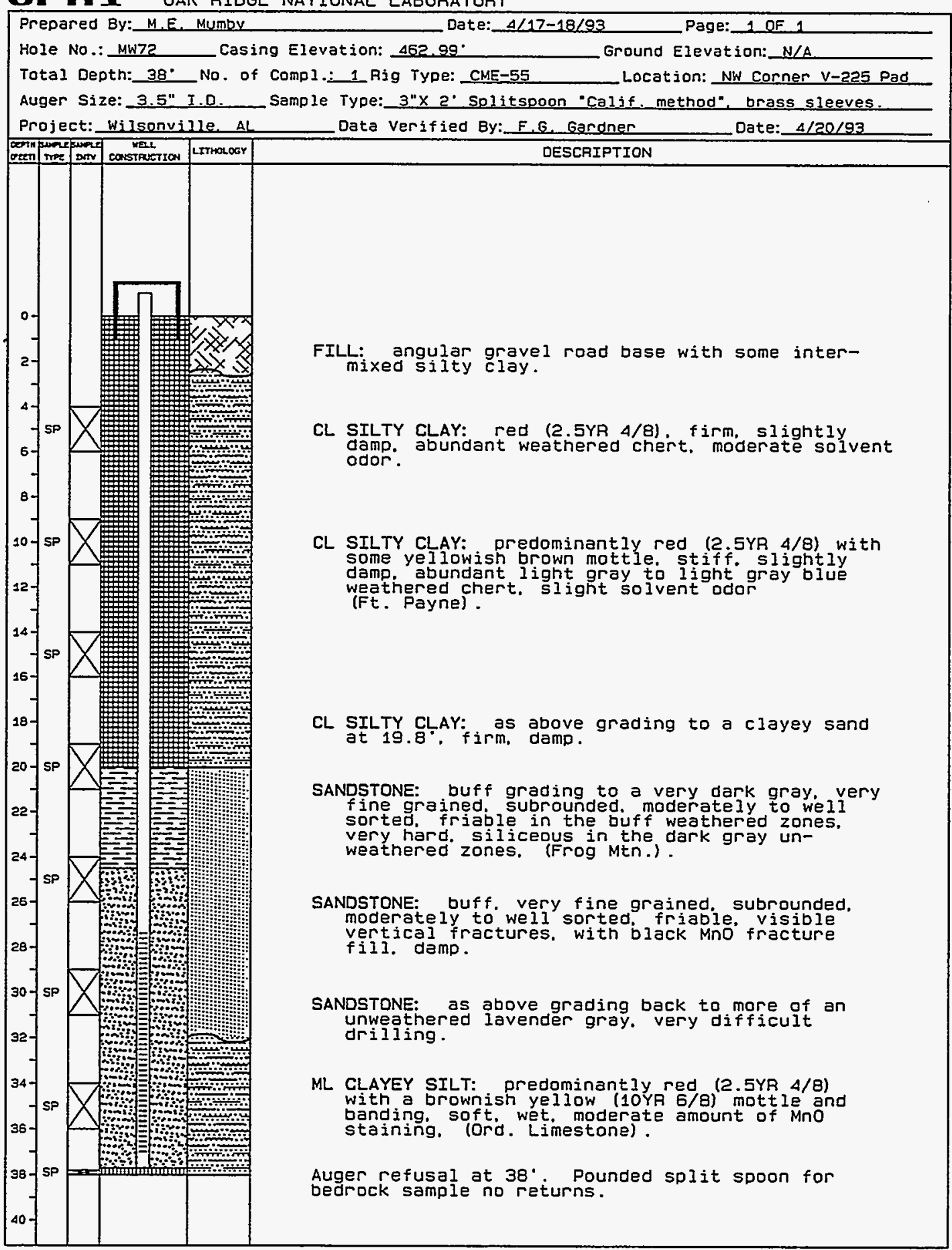


0III OAK RIDGE NATIONAL LABORATORY

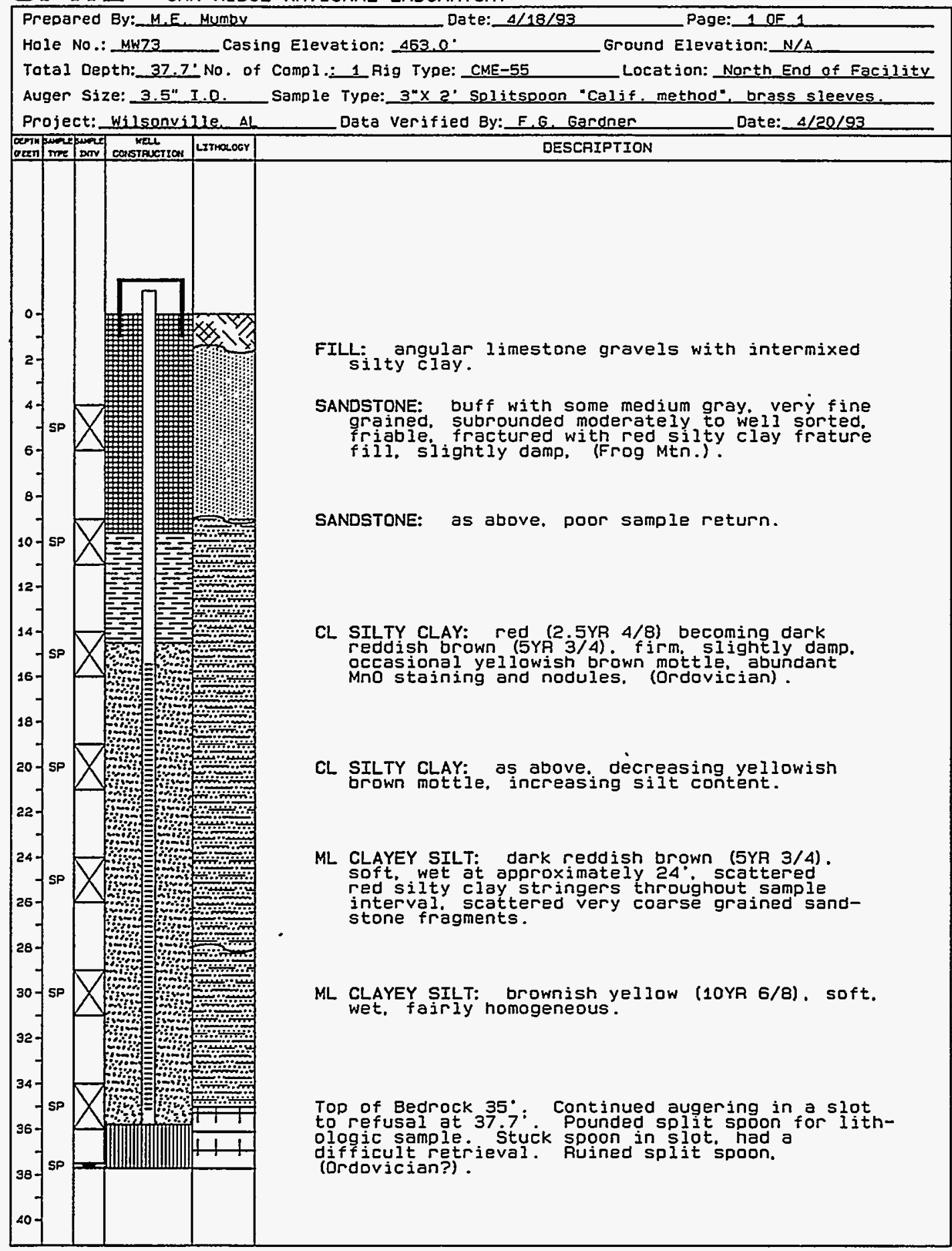



Bedrock Well Logs 


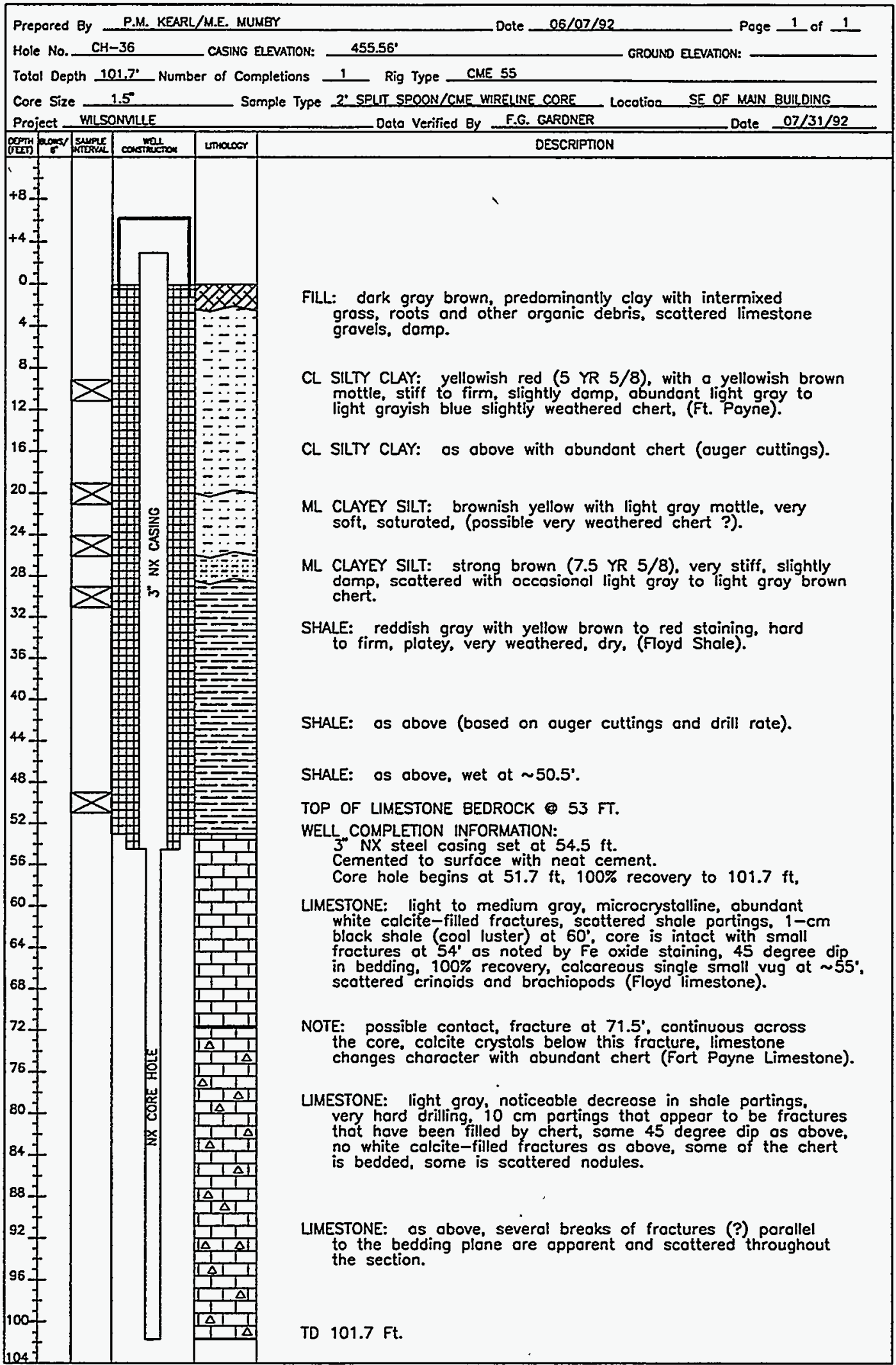




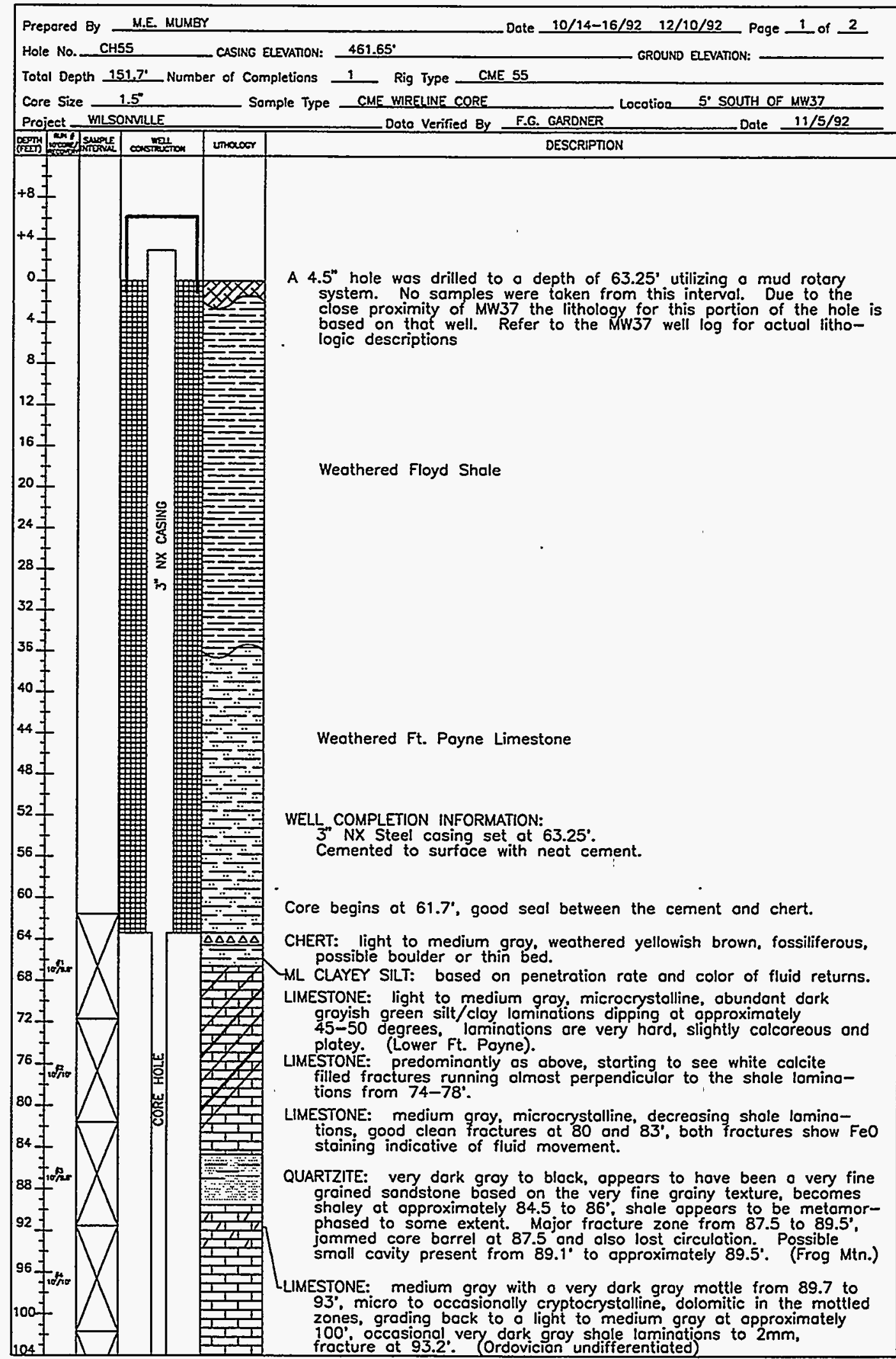


ornl

Well Summory Information

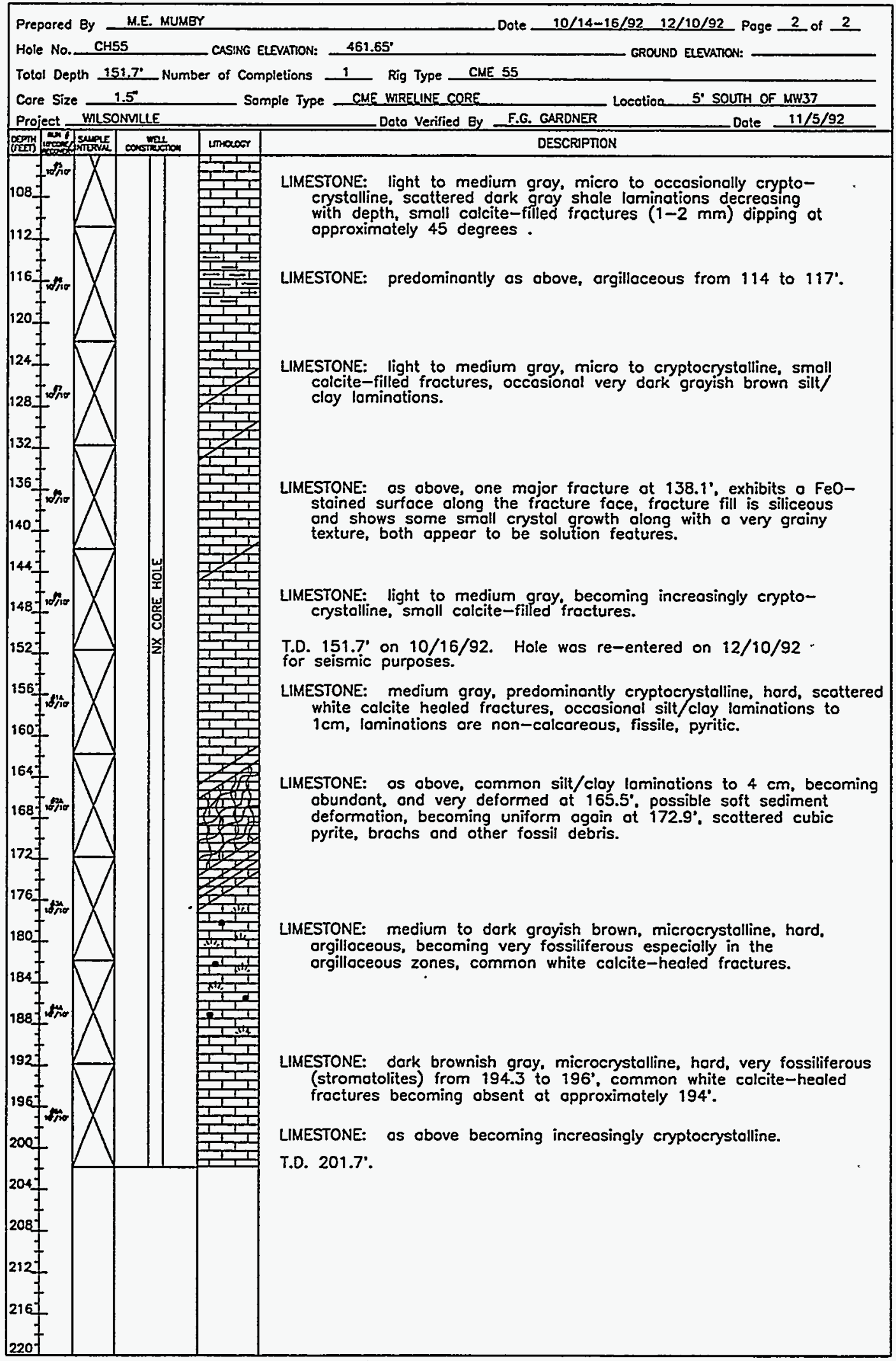




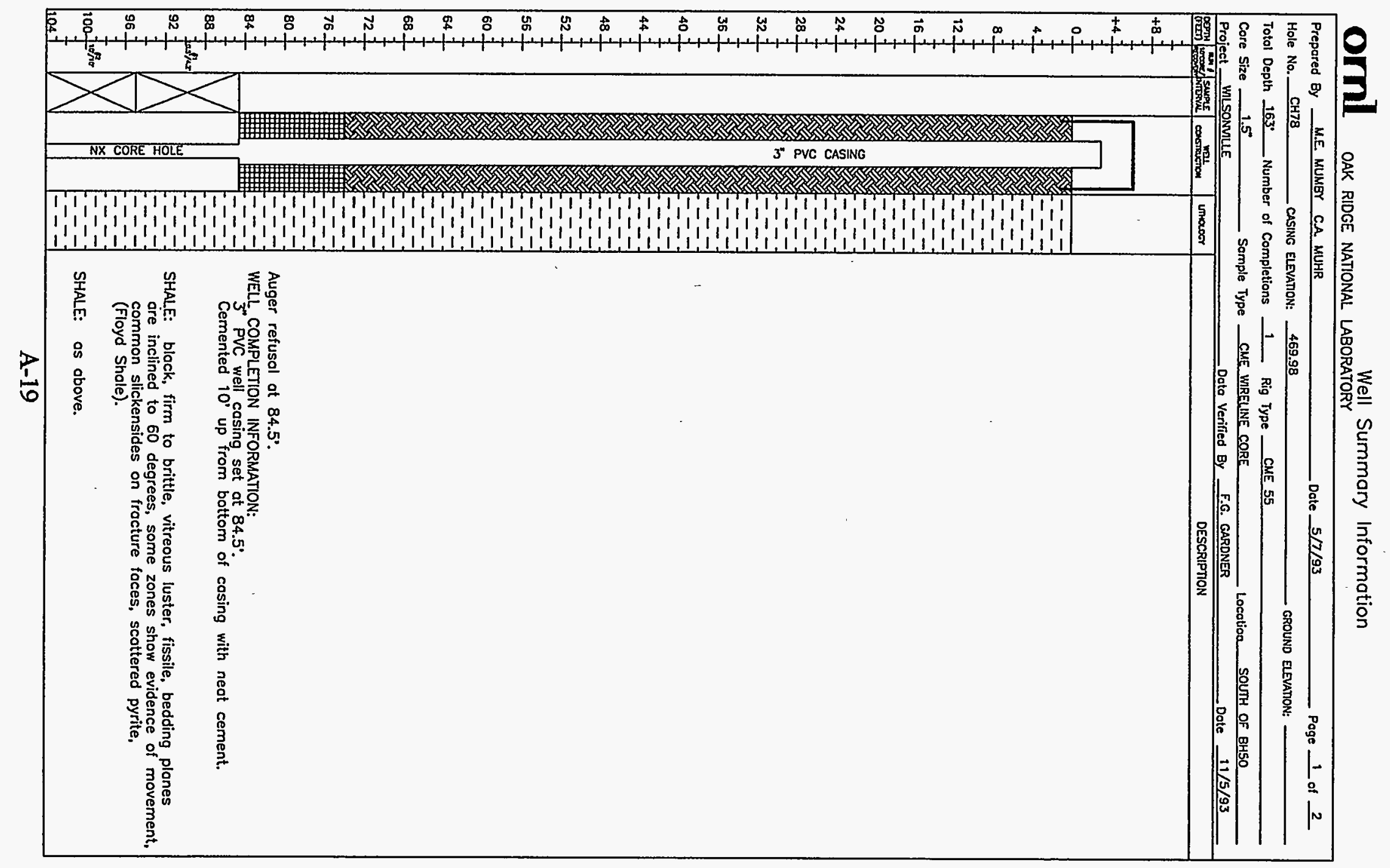




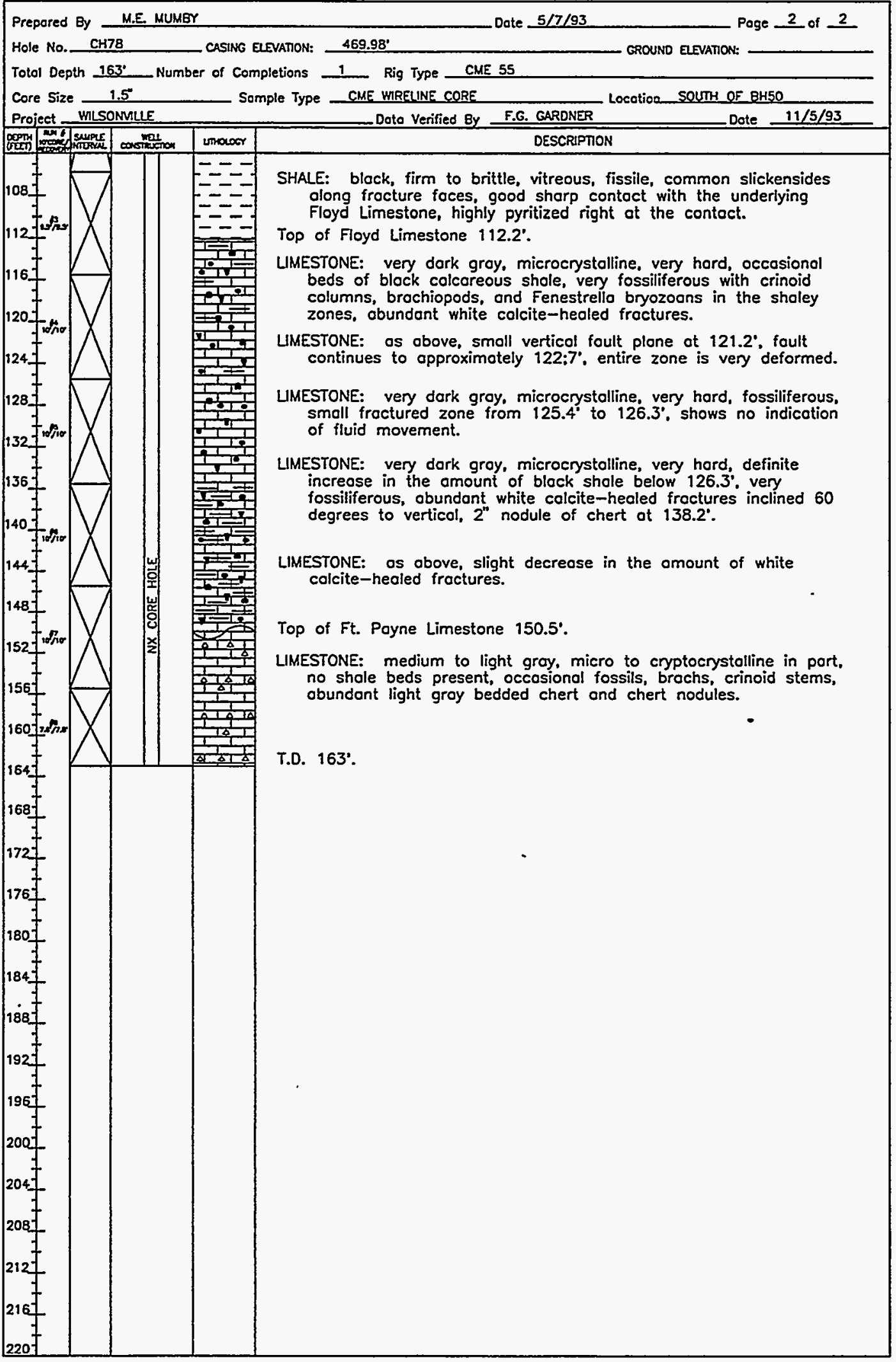




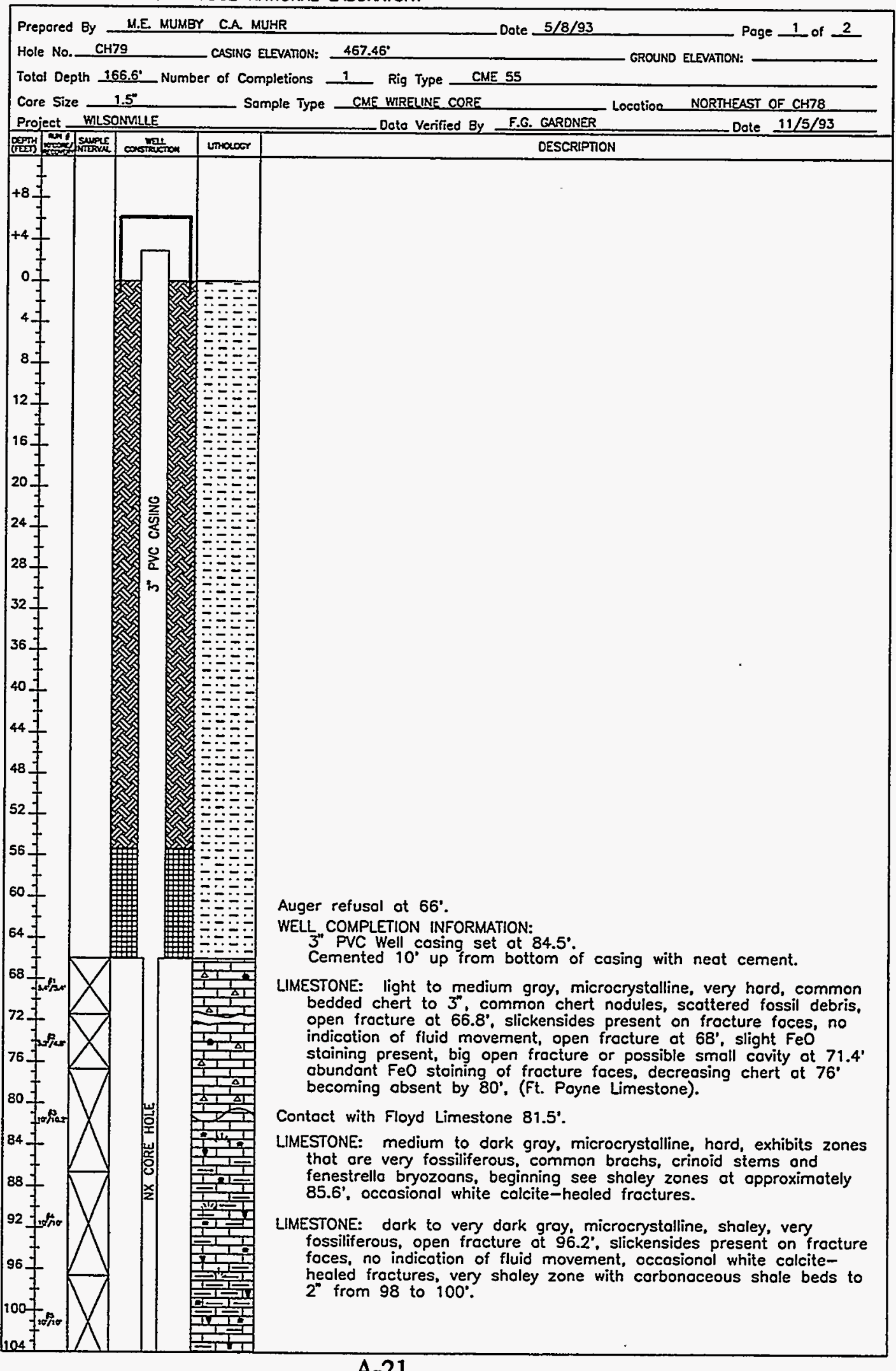


OMI OAK RIDGE NATIONAL LABORATORY Summary Information

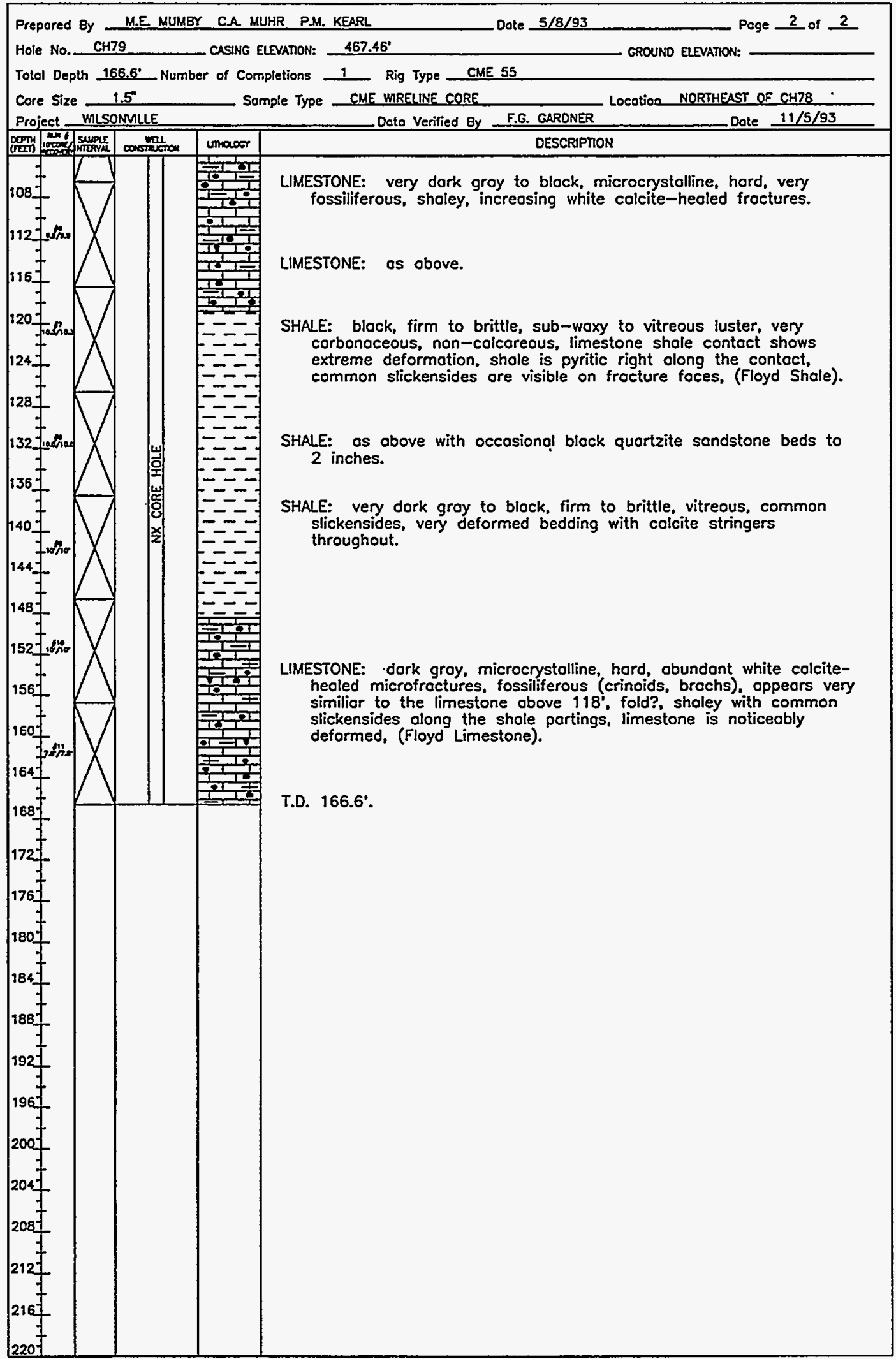




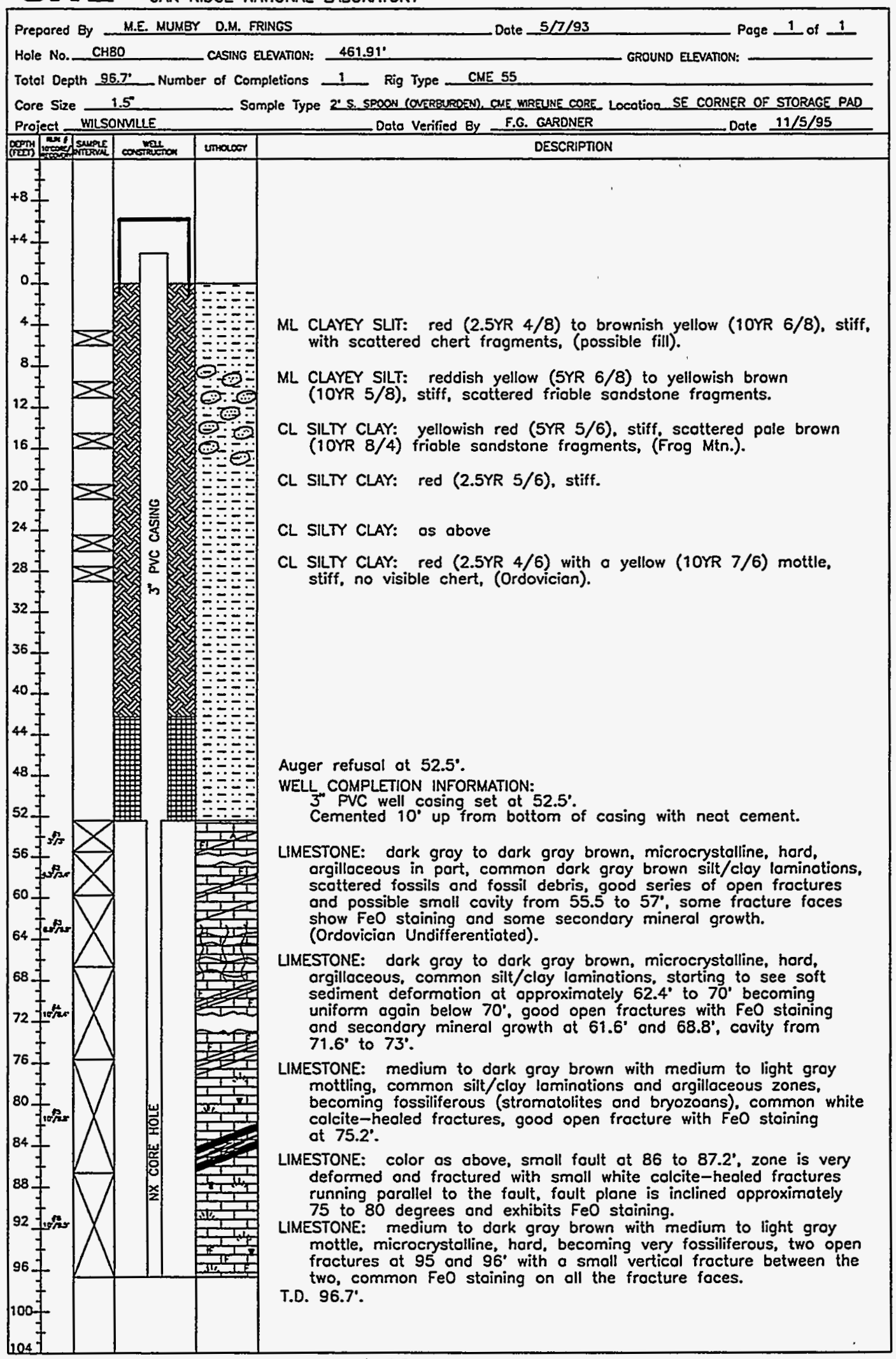




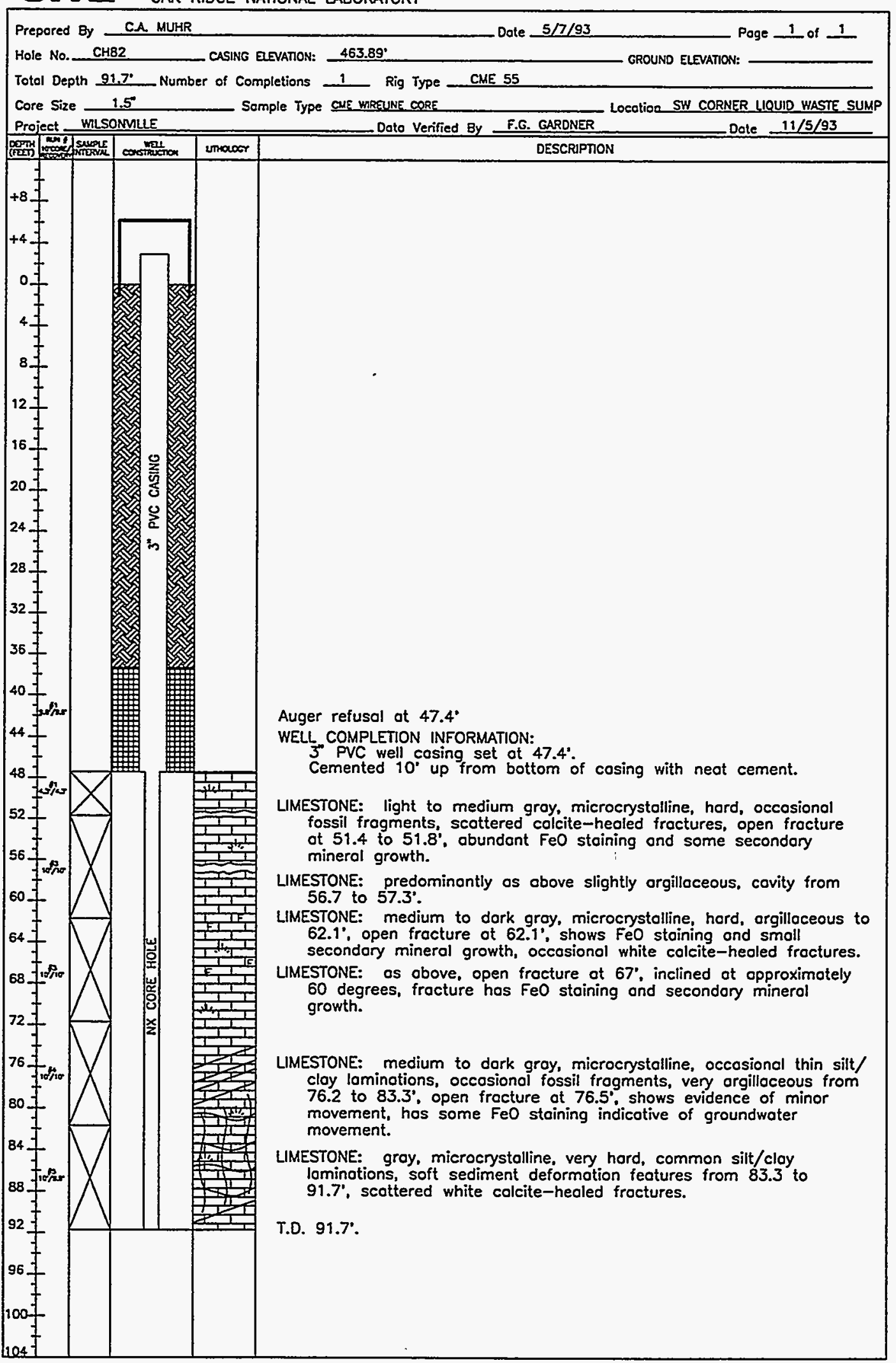




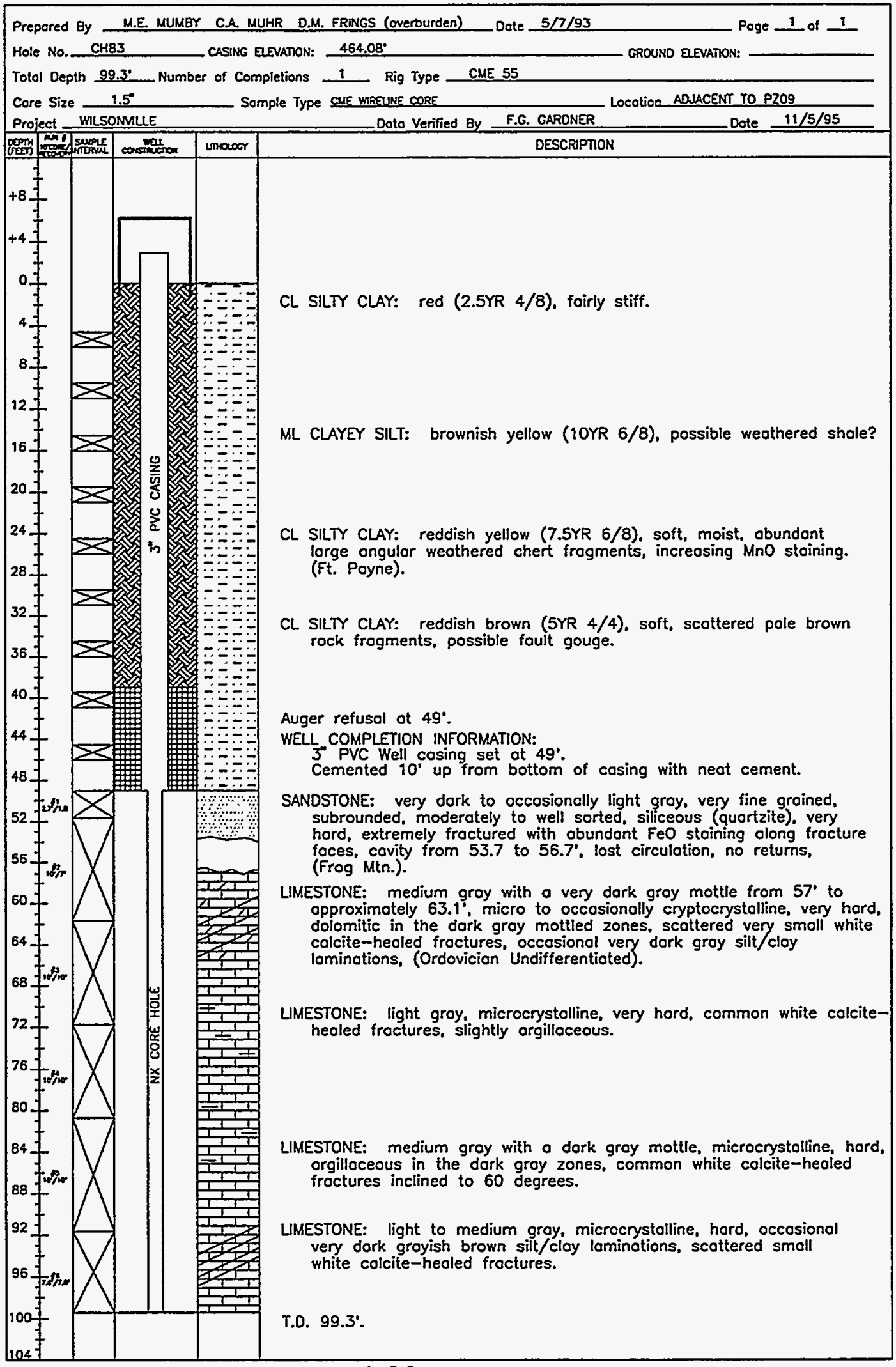




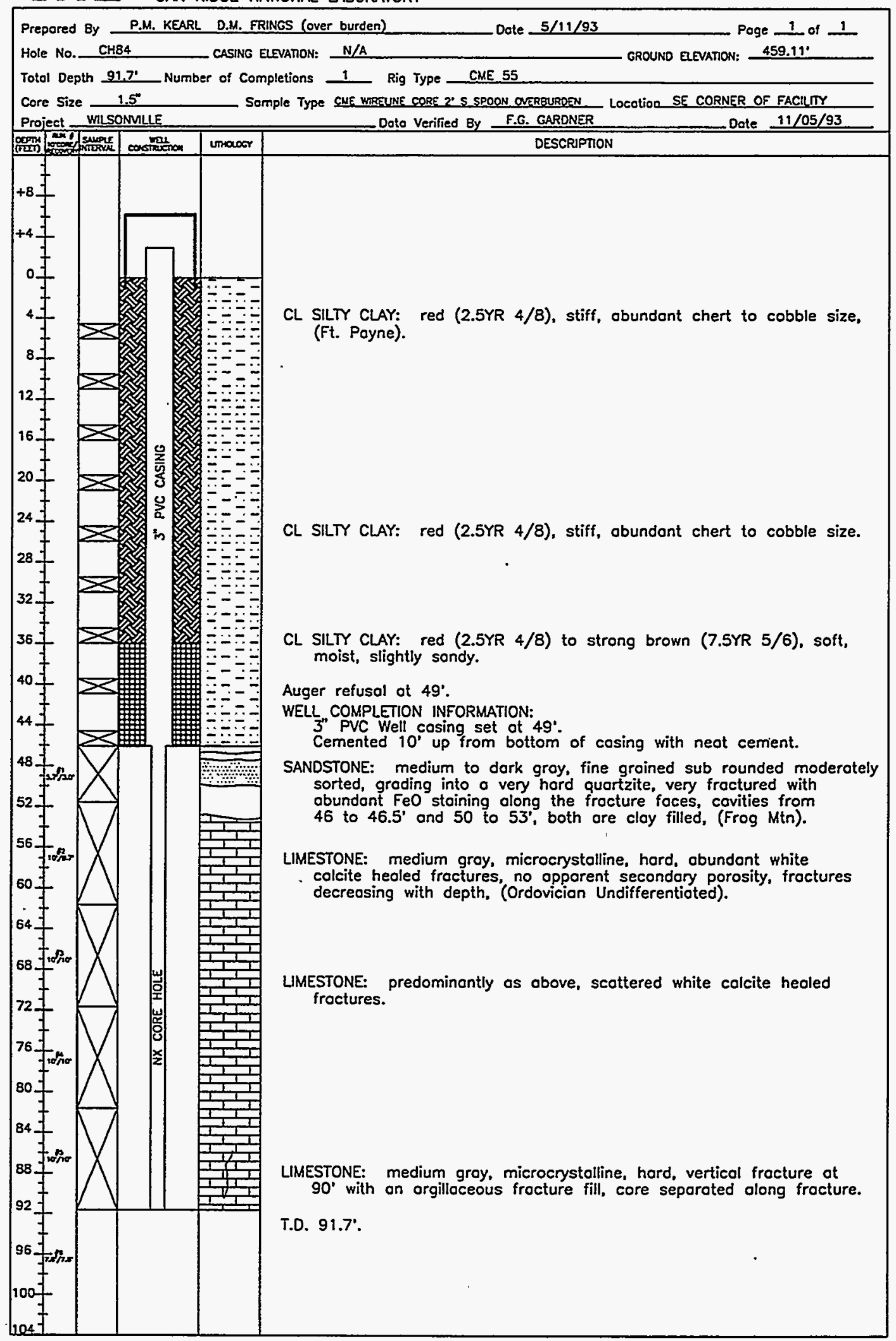


ornl

Well Summary information

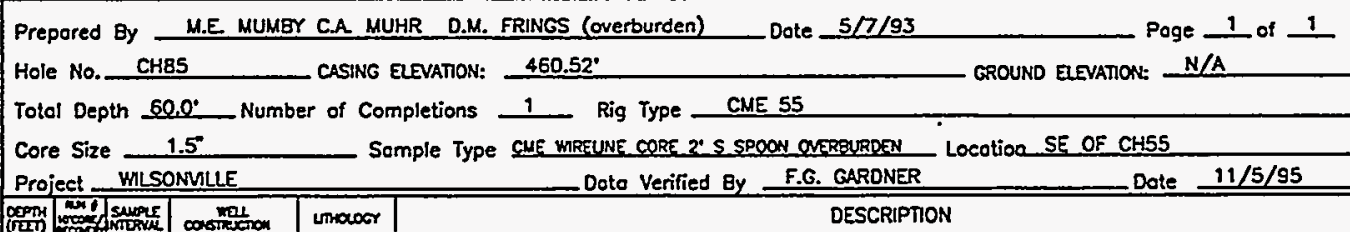

Fill:
limestone oggregote.

SHALE: strong brown (7.5YR 5/6) to gray (7.5YR n5) to red (2.5YR 5/8), firm, banded, very weathered, (Floyd Shale).

Auger refusal ot $49^{\circ}$.

WELL COMPLETION INFORMATION:

$3^{\circ}$ PVC Well cosing set ot $49^{\circ}$.

LIMESTONE: very dark groy to black, microcrystalline, hord, shaley, very fossiliferous with obundont brachiopod, crinoid and bryozoon frogments, large covity from 28.6 to $38.5^{\circ}$, lost circulation, covity is filled with chert rubble and very dark brown limey mud, chert rubble is extensively stoined with $\mathrm{FeO}$ indicoting fluid movement. (Ordovicion Undifferentioted).

LIMESTONE: as above, large open solution features ore present and filled with a ton limey mud, mud is very fossiliferous with Fenestrello bryozoon fragments the most prevalent, cavity from 39.7 to $41.7^{\circ}$. lorge covity from 42.2 to $51^{\circ}$, covity is filled with Feo-stained chert rubble.

Covity from 51.7 to $53.2^{\prime}$.

LIMESTONE: light groy, microcrystolline, very hord, obundant nodules and beds of light to dark gray chert, beds ronge in thickness from 1 to $3^{\prime \prime}$, scottered fossil debris, occosional open froctures with no indication of fluid movement.

T.D. $60^{\circ}$. 


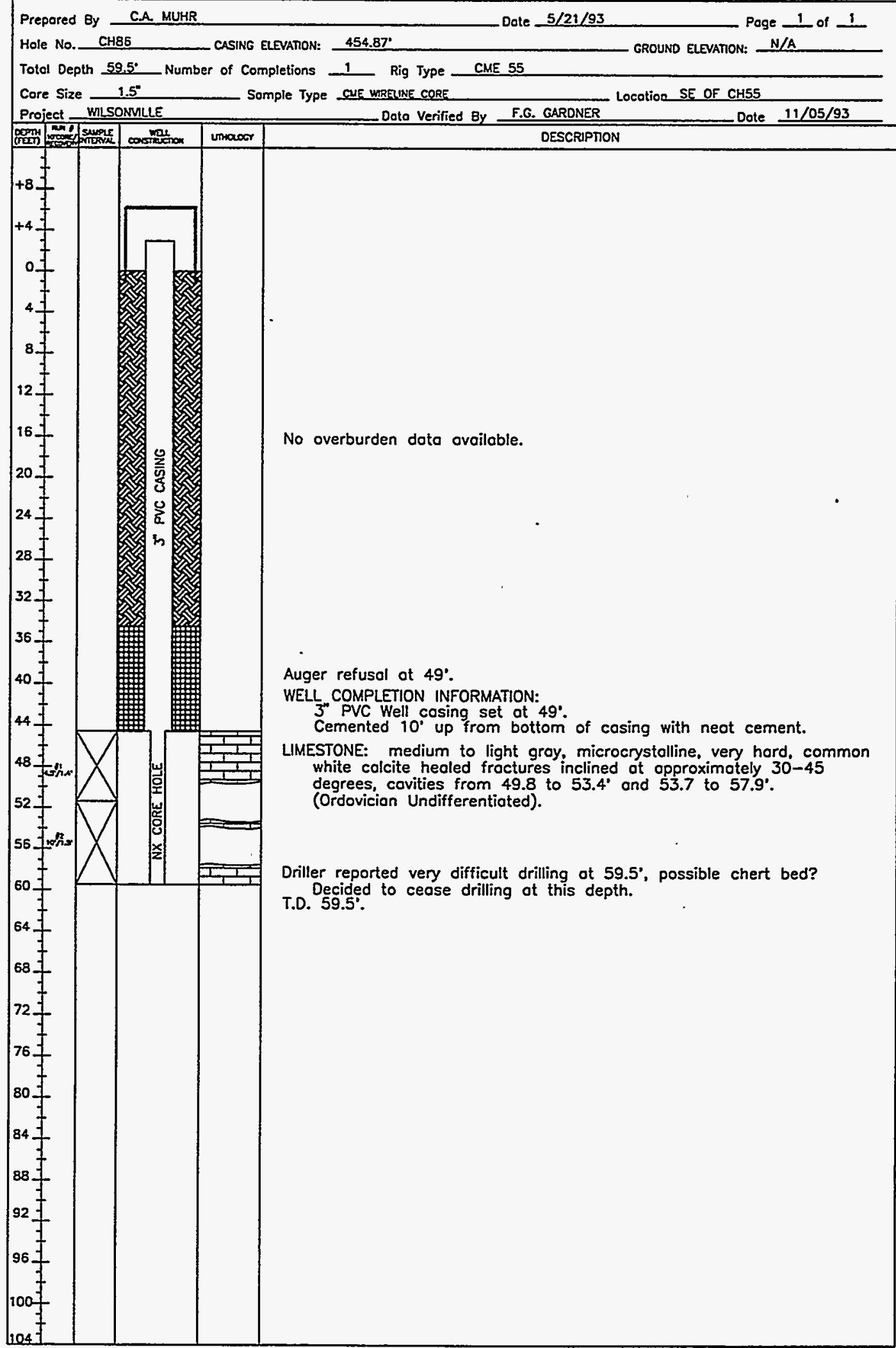


ornl

Well Summary Information

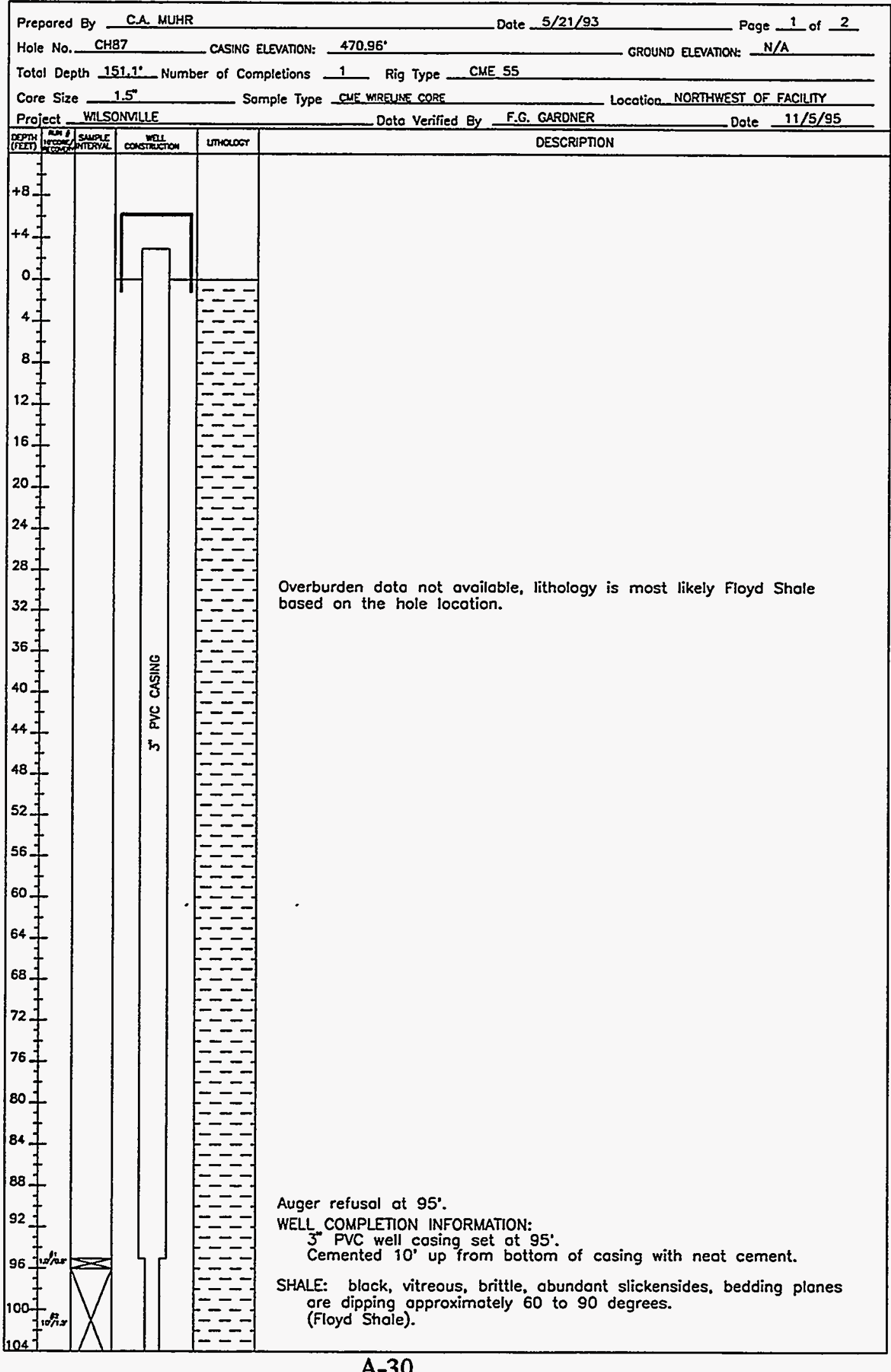


QII OAK RIDGE NATIONAL Summary information

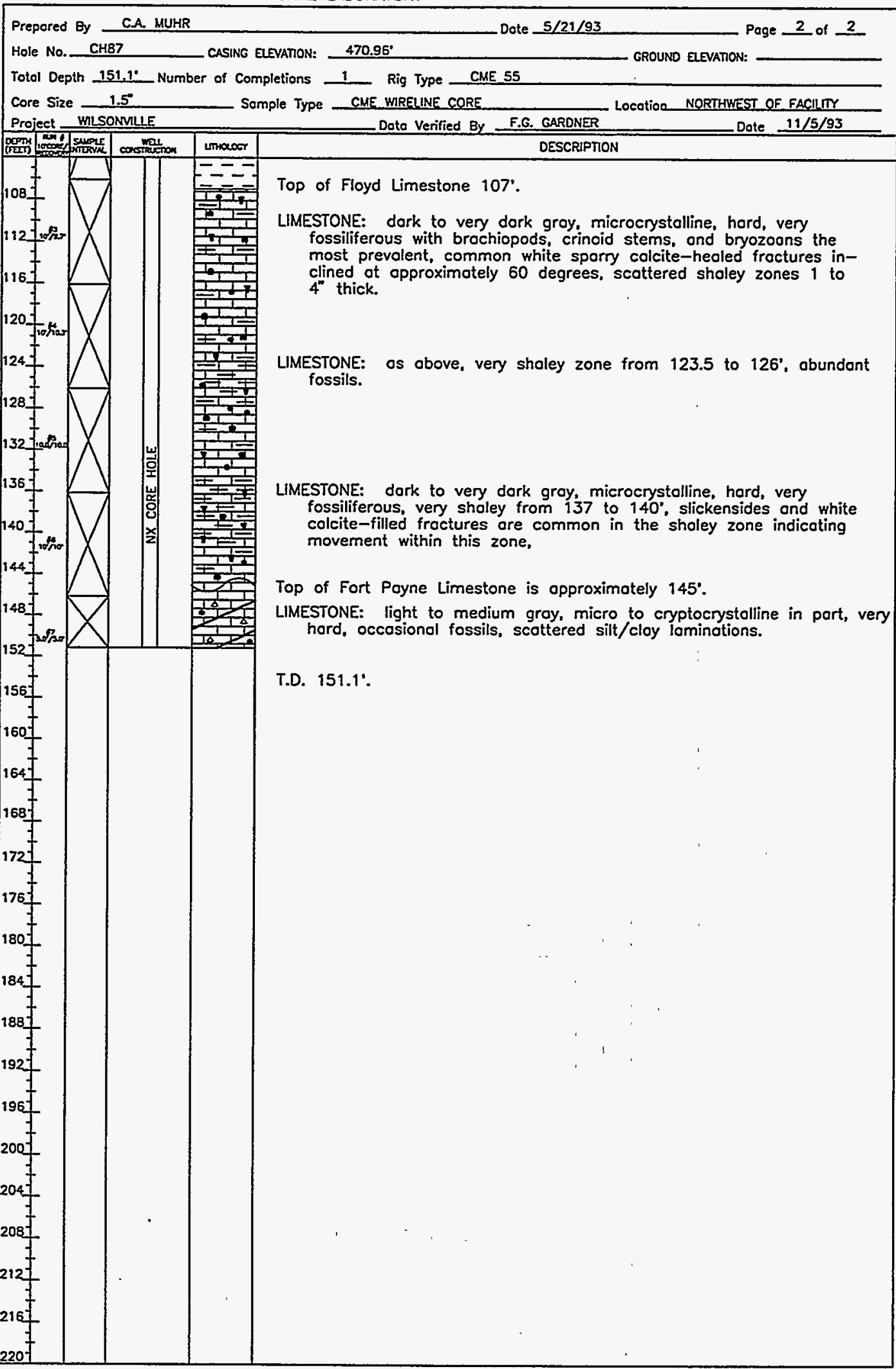




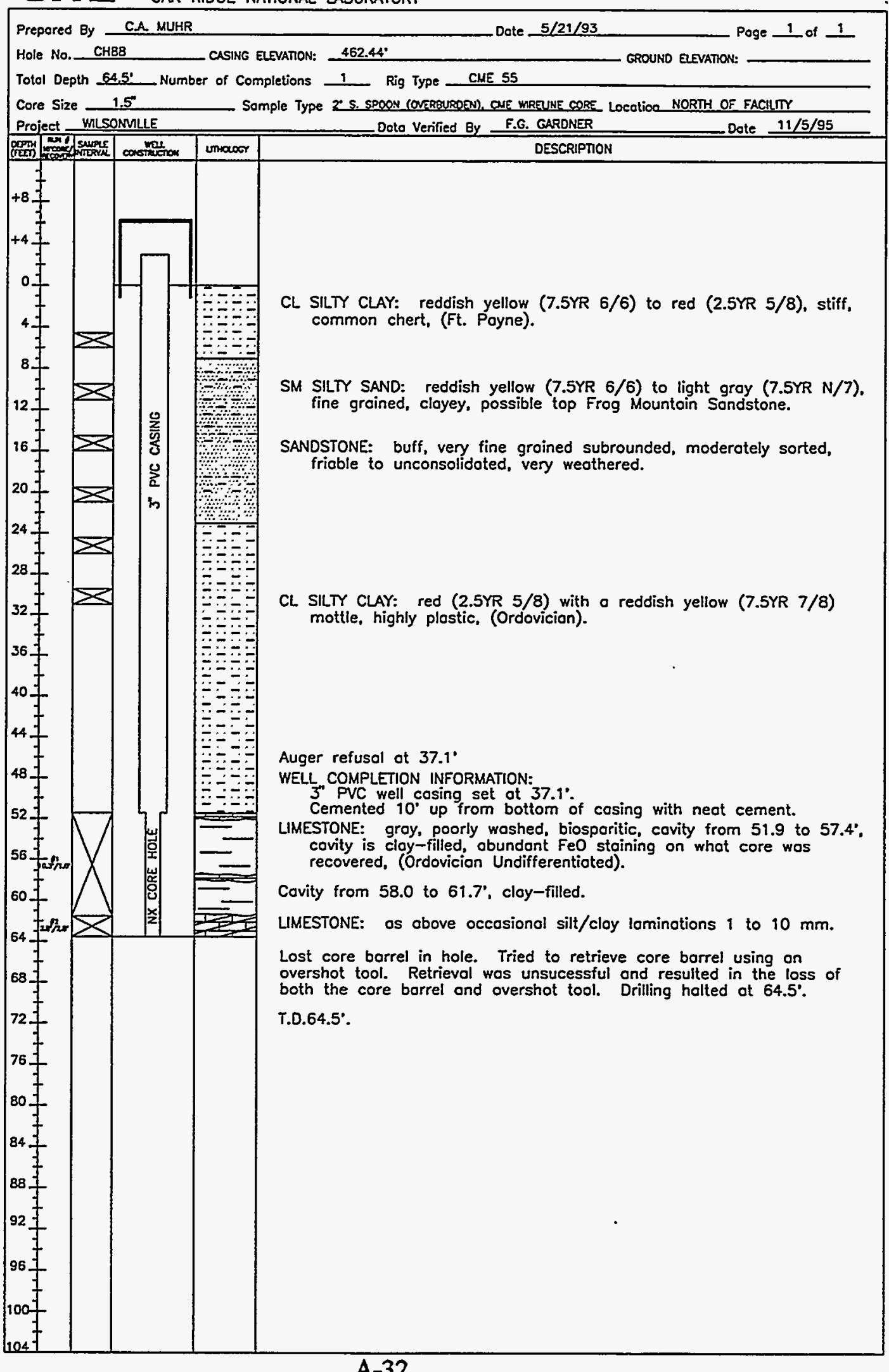


Piezometer Logs 

orn 1

Well Summary Information

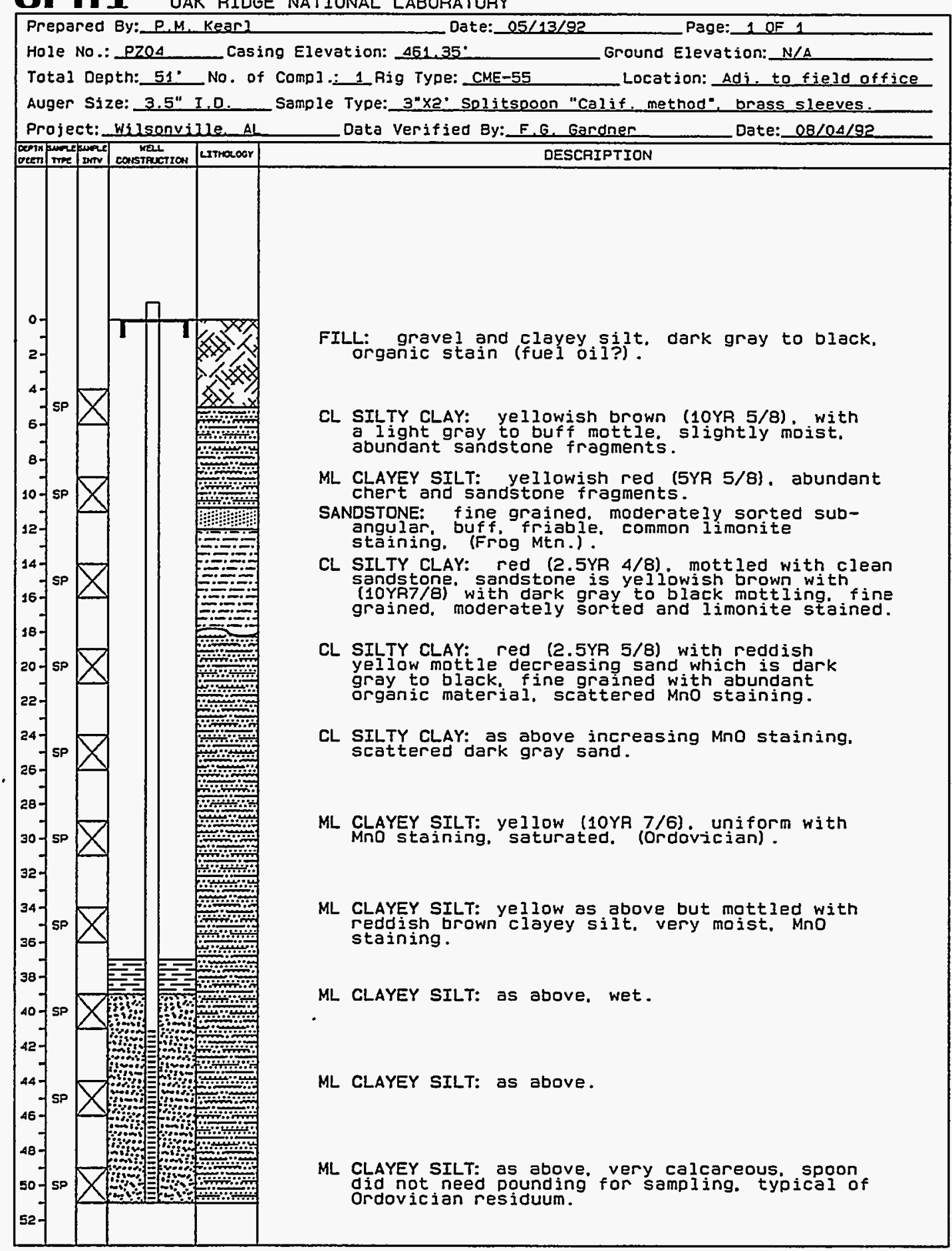




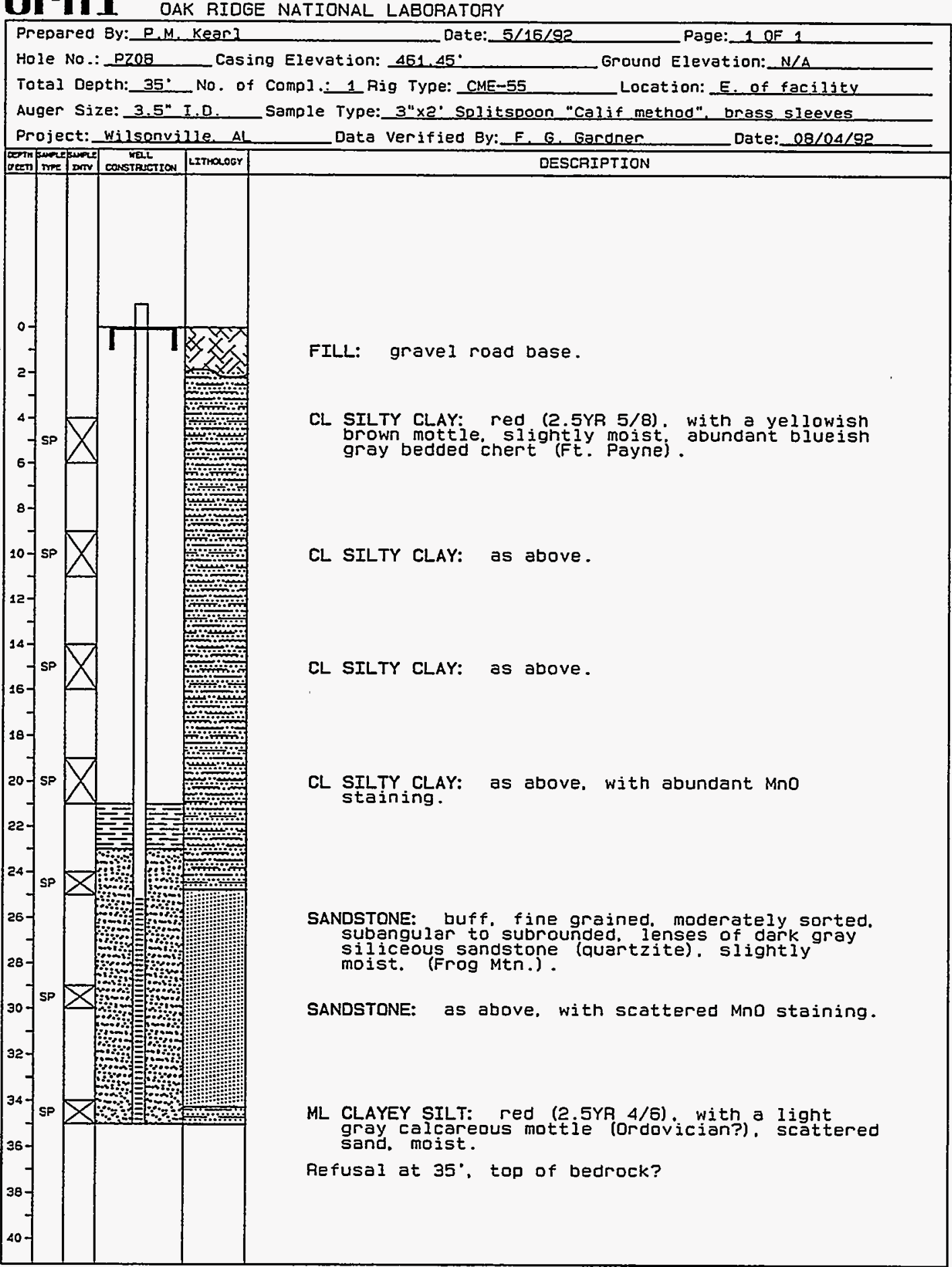


Orn] OAK RIDGE NaTIONAL LABORATORY

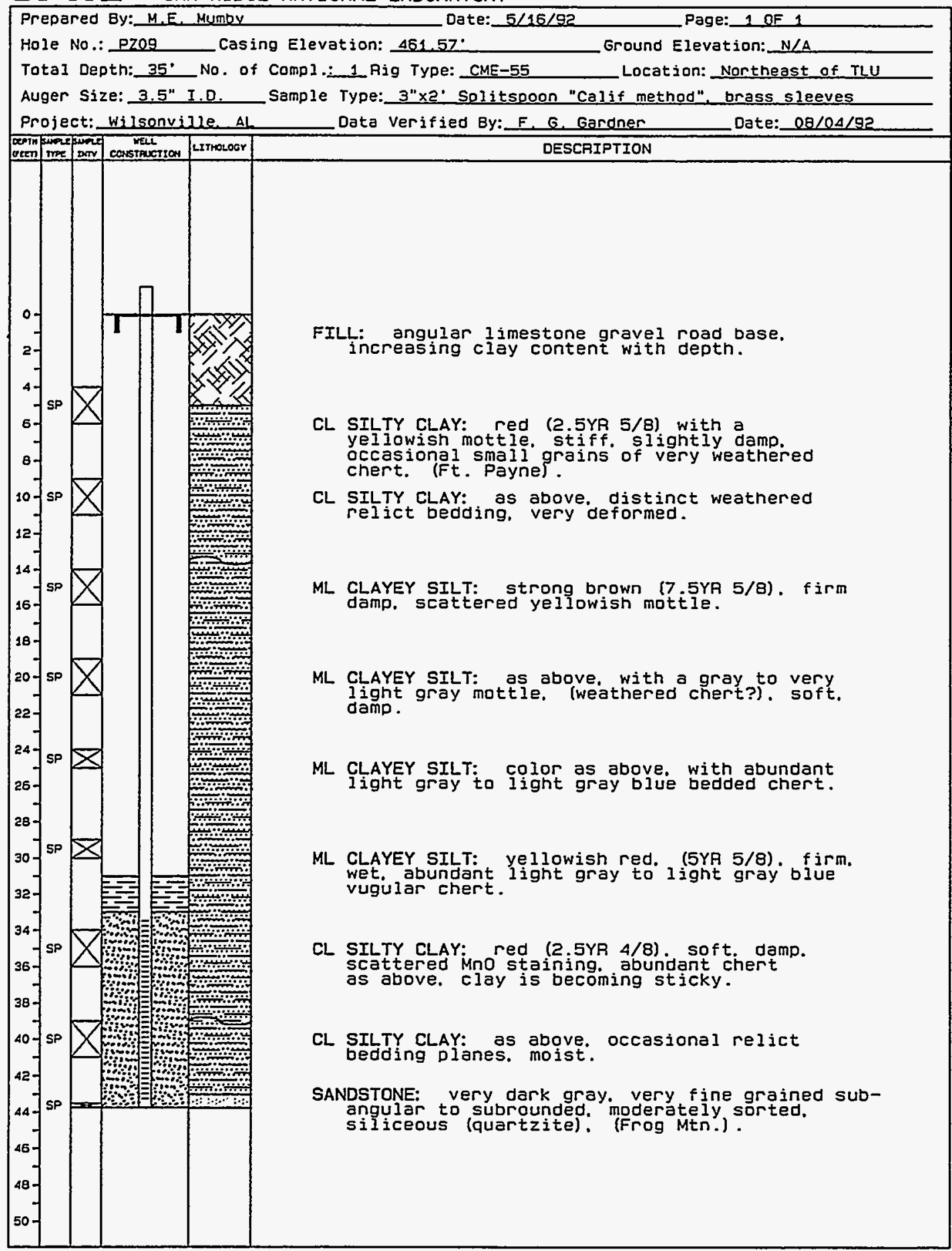




\section{$\operatorname{orn} 1$}

Well Summary Information

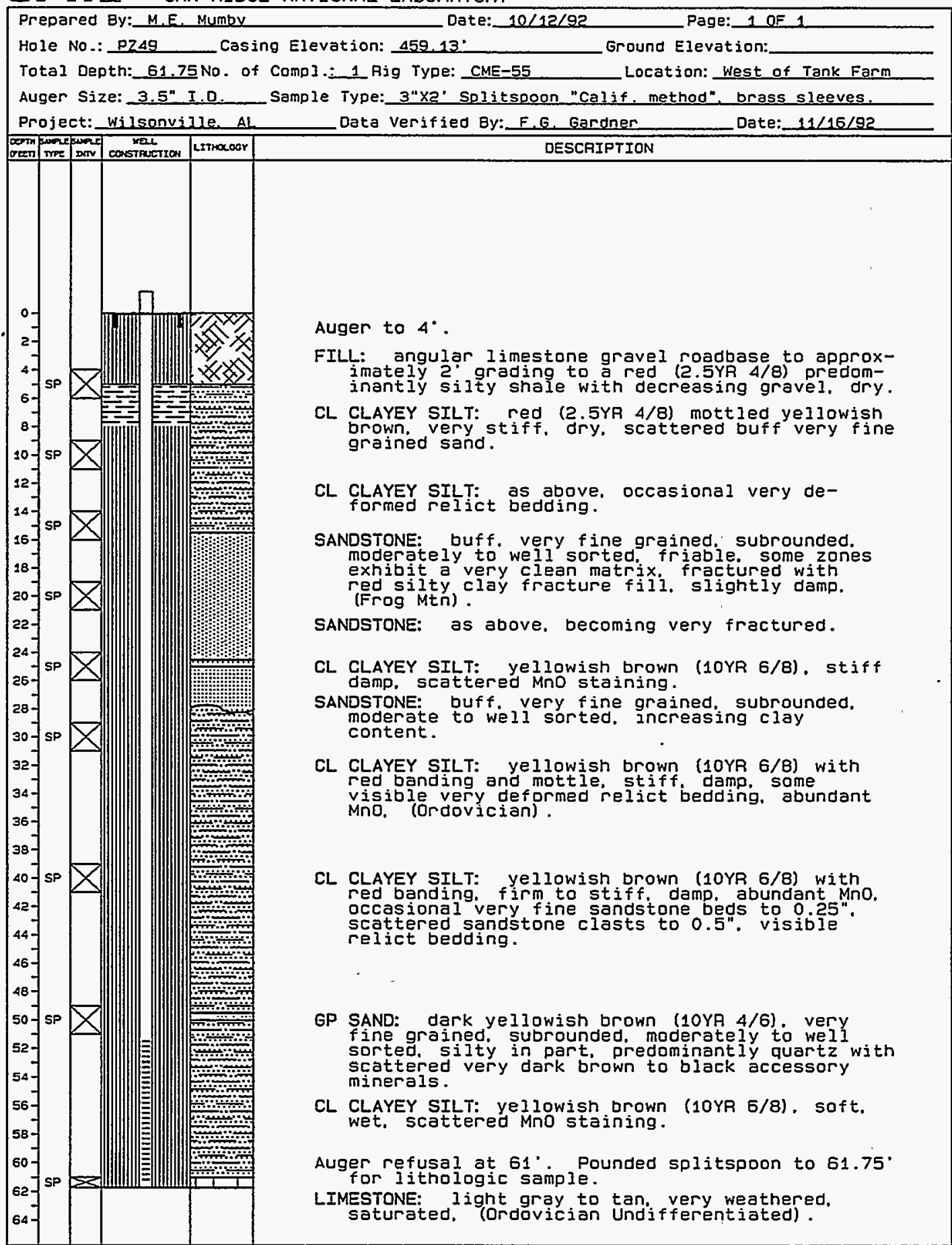




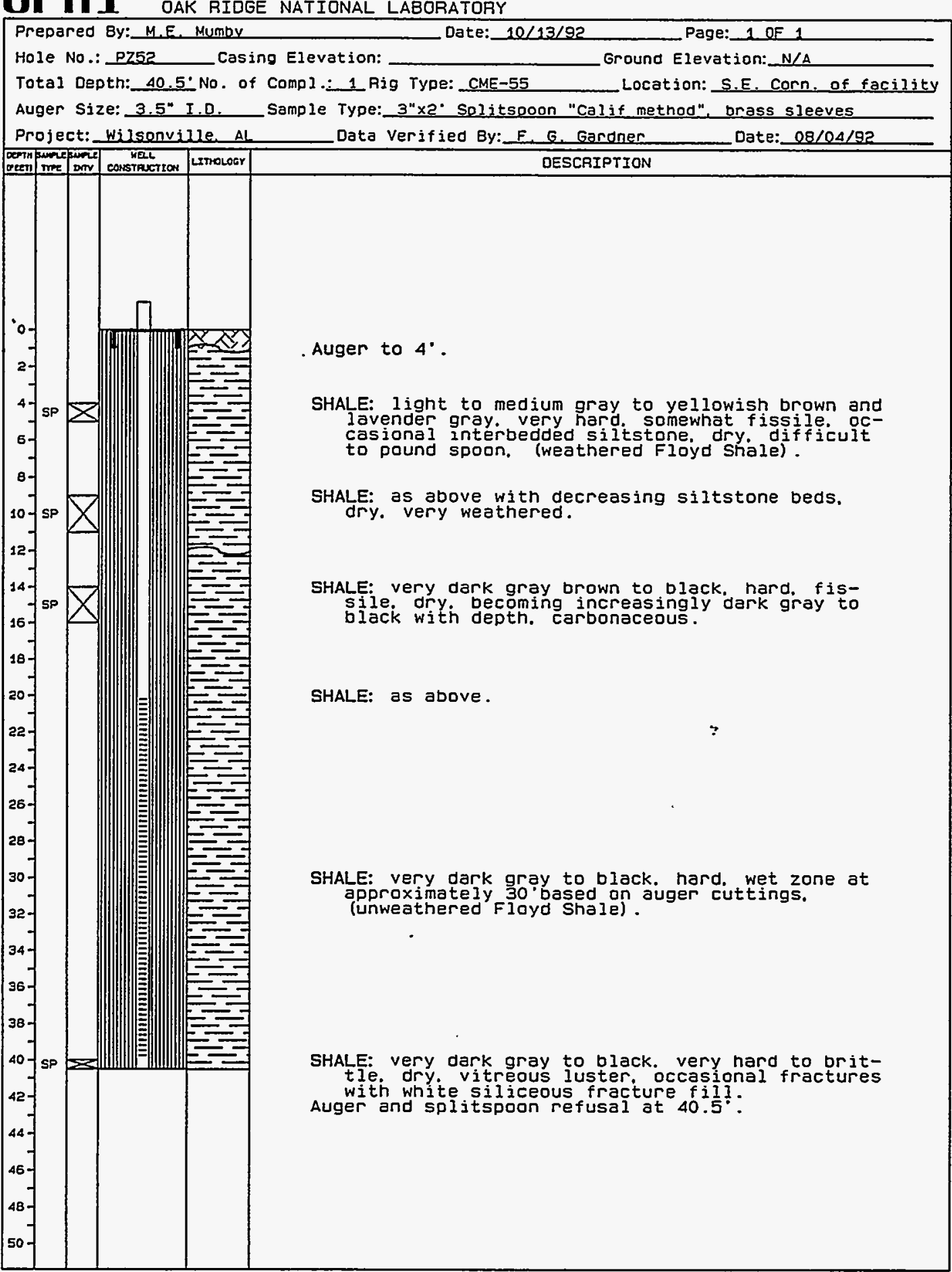




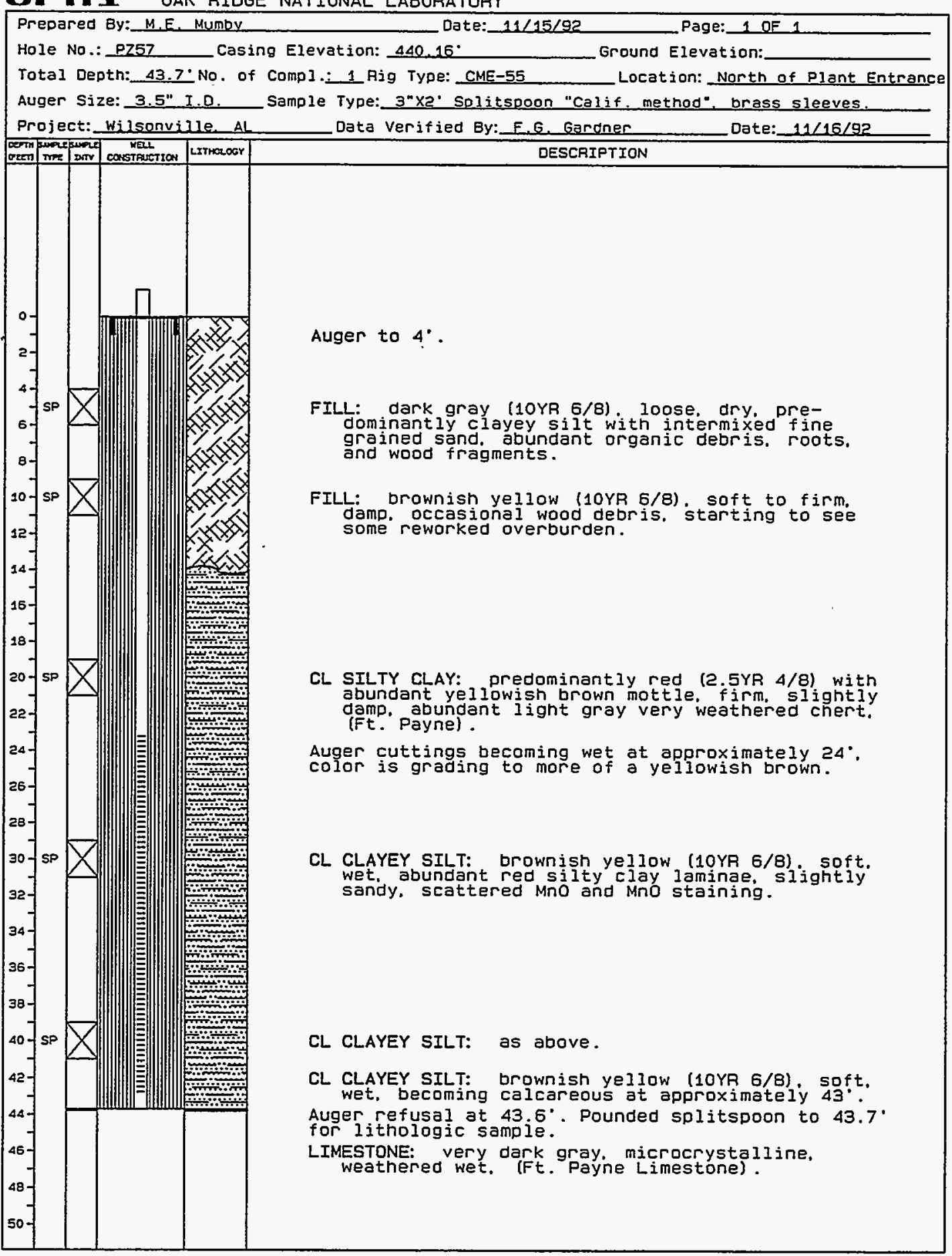


Soil Boring Logs 
orn I

Borehole Summary Information

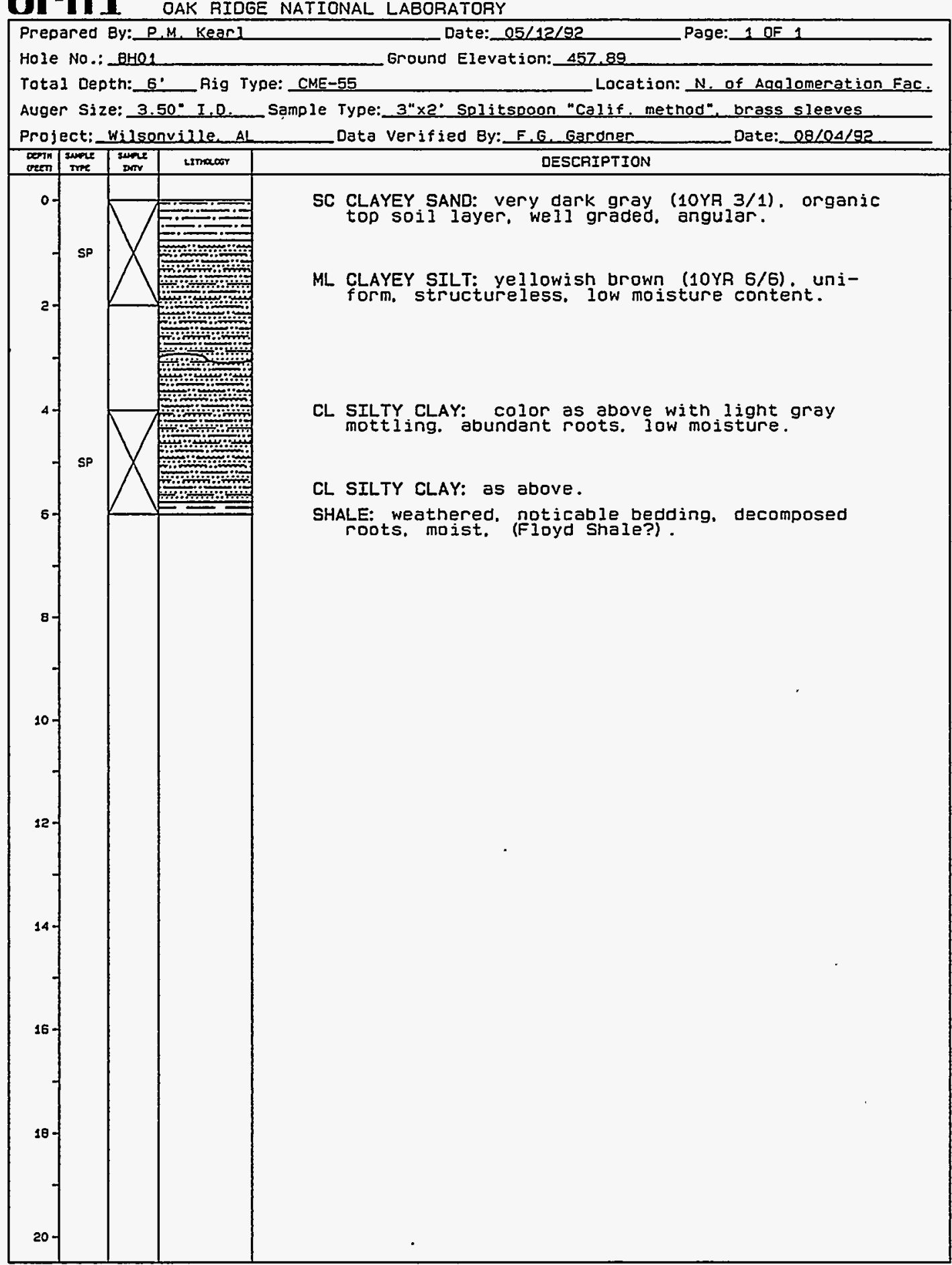


QIII OAK RIDGE NATIONAL LABORATORY

Borehole Summary Information

Prepared By: P.M. Kearl
Hole No.: BHO2 Ground Elevation: 456

Hole No.: $\mathrm{BH}$ Toz

Page: 1 OF 1

Location: $N$. of Agajomeration Fac.

Auger Size: $3.50^{\circ}$ I.D

Sample Type: $3^{\prime \prime} \times 2^{\circ}$ Splitspoon "Calif. method". brass sleeves

Project: Wilsonville. Al__Data Verified By:_F,G, Gerdner_ Date: $08 / 04 / 92$

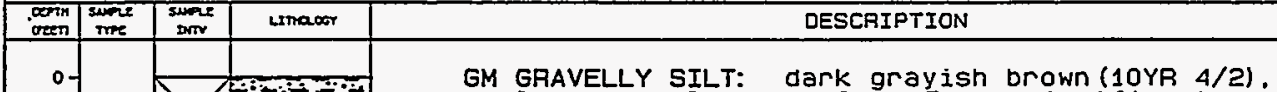
GM GRAVELY SILT: dark grayish brown (10YR $4 / 2)$
large angular gravel to 5 cm, significant am-
ounts of sand. very moist. al iuvial material in
swale.

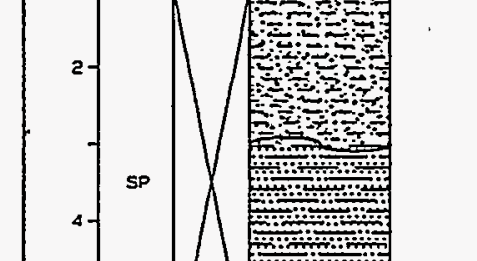

ML CLAYEY SILT: brownish yellow (10YR 6/8), moist. large nodules and partings of Mno(?). 
0II OAK RIDGe national Laboratory

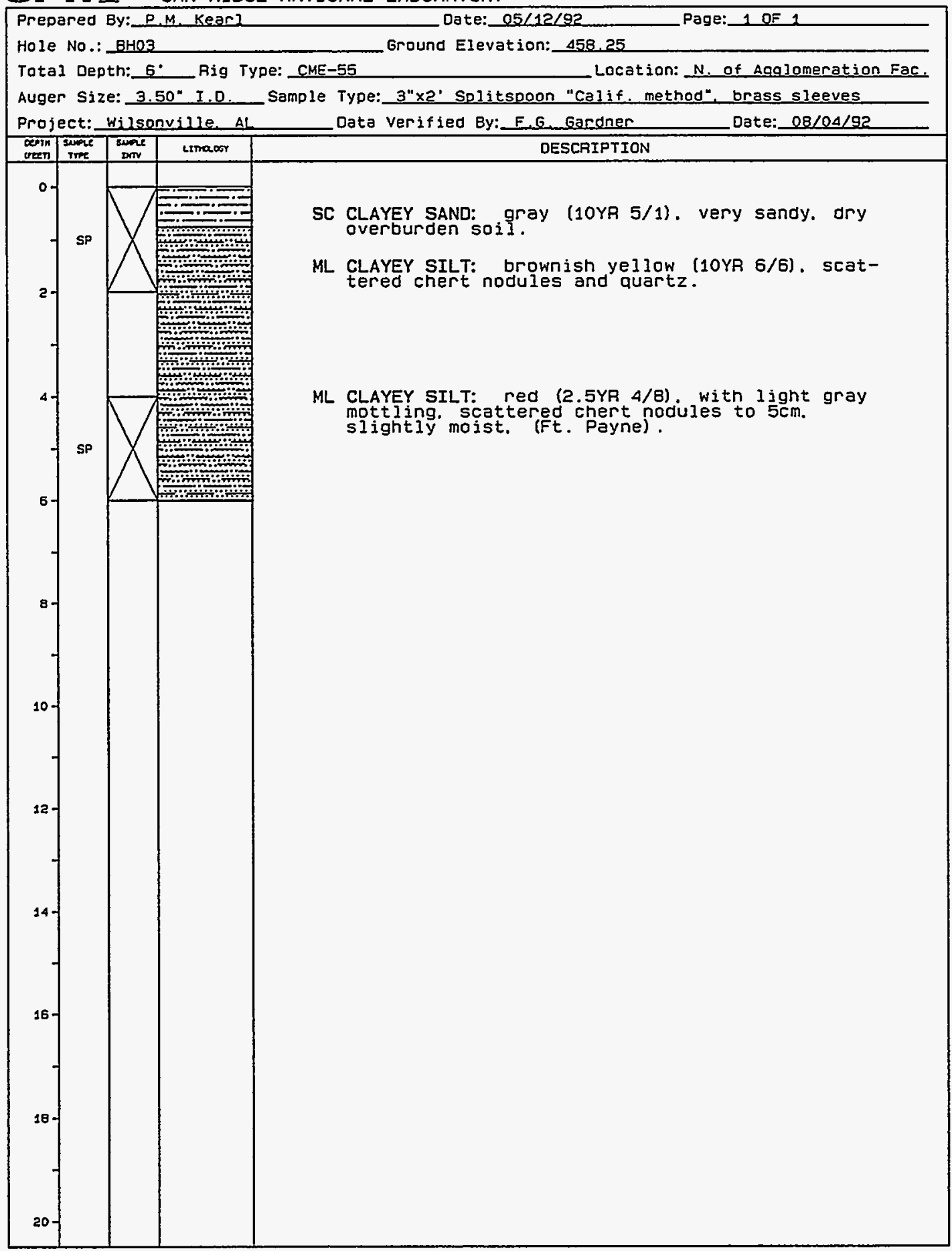


0III OAK RIDGE National LabORATORY

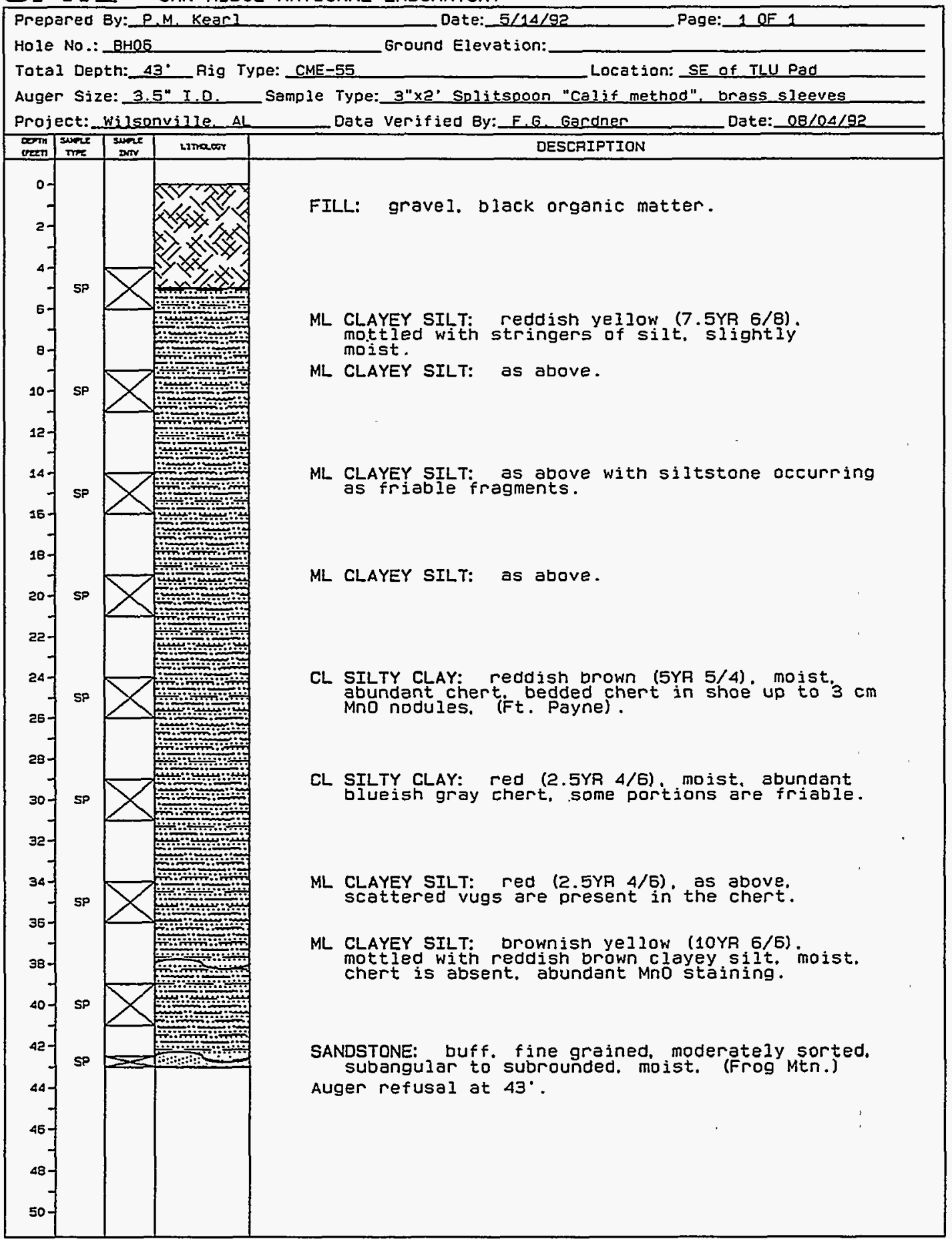


OP1 Borehole Summary Information

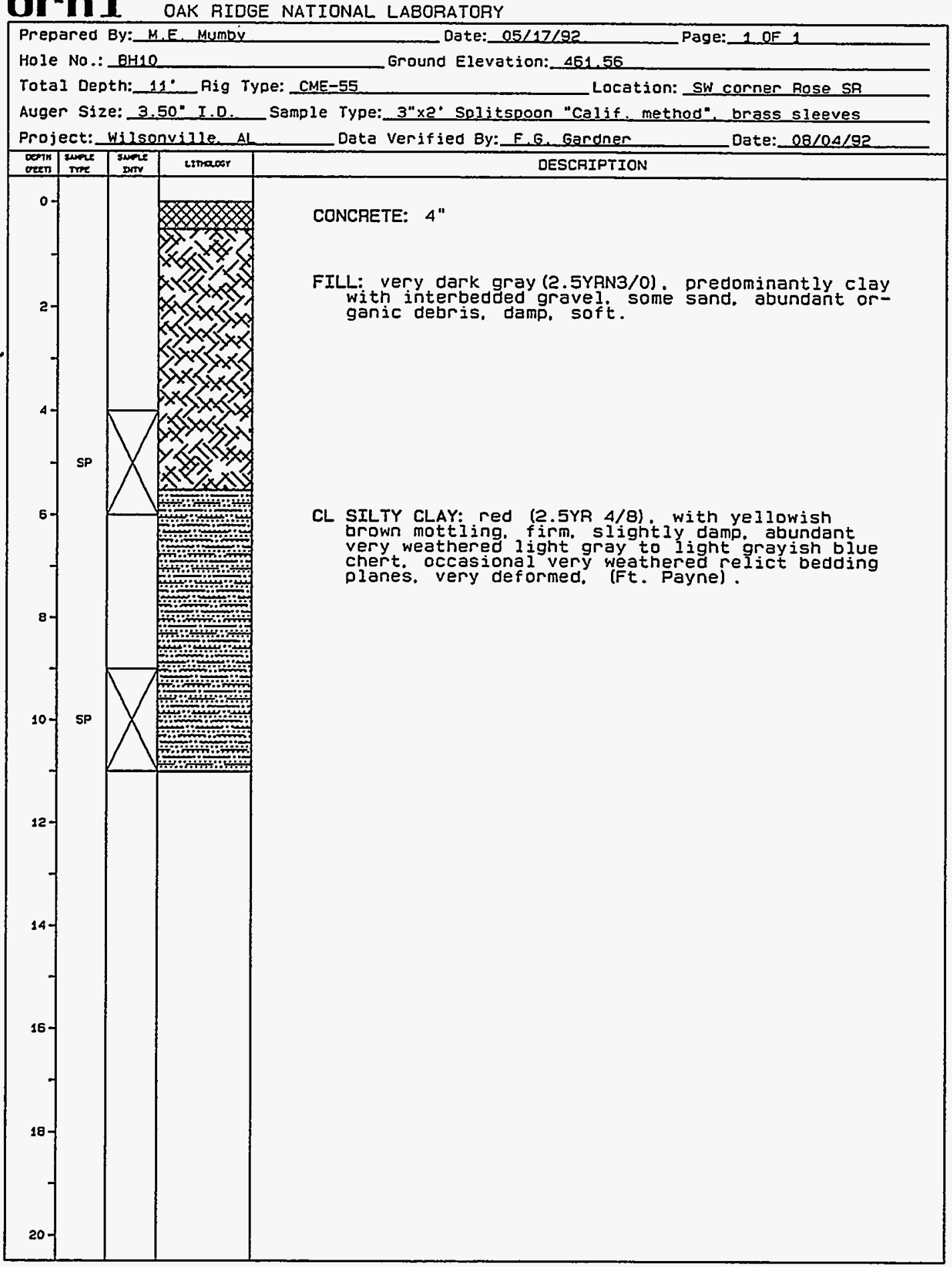


orn1

Borehole Summary Information

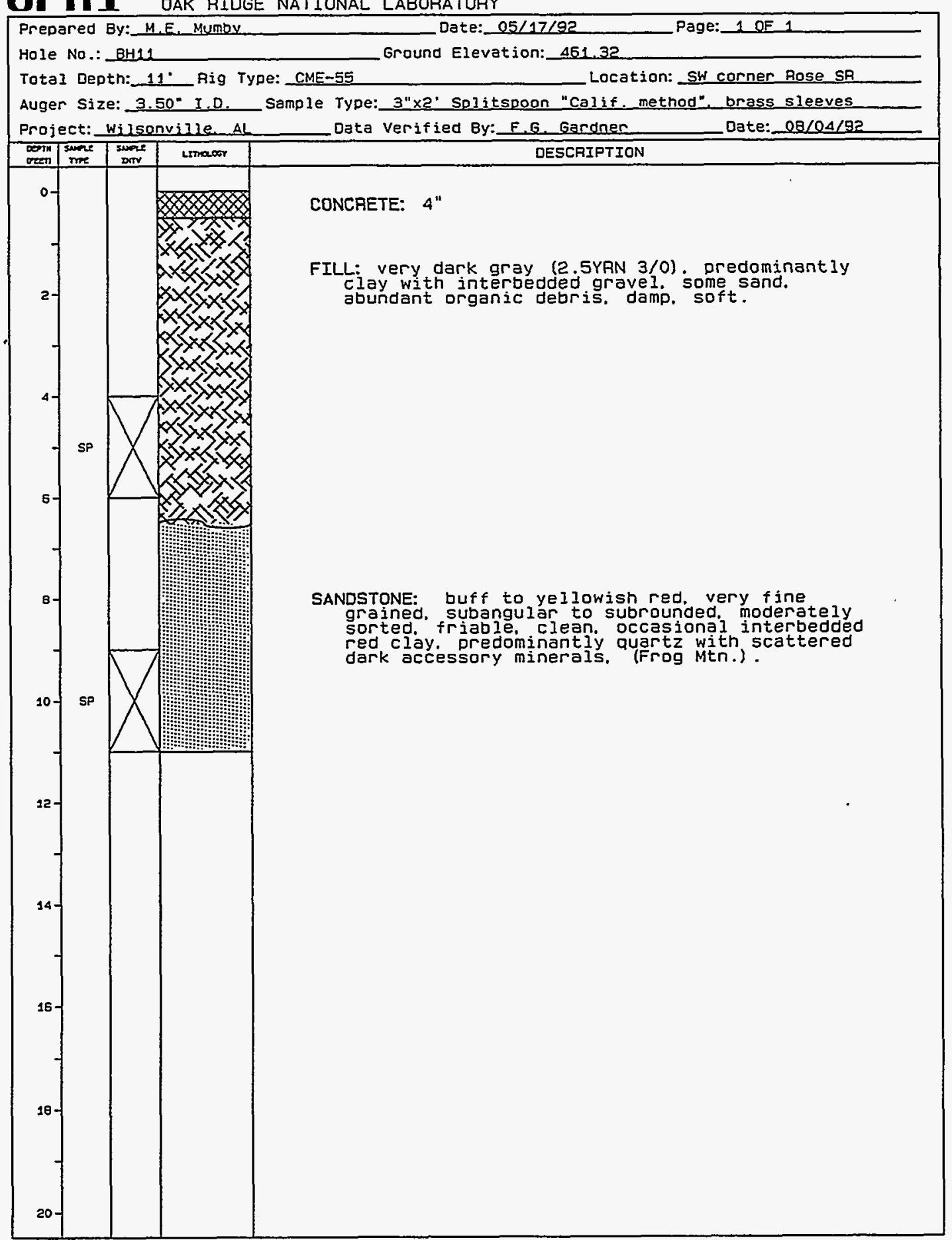


orn 1

Borehole Summary Information

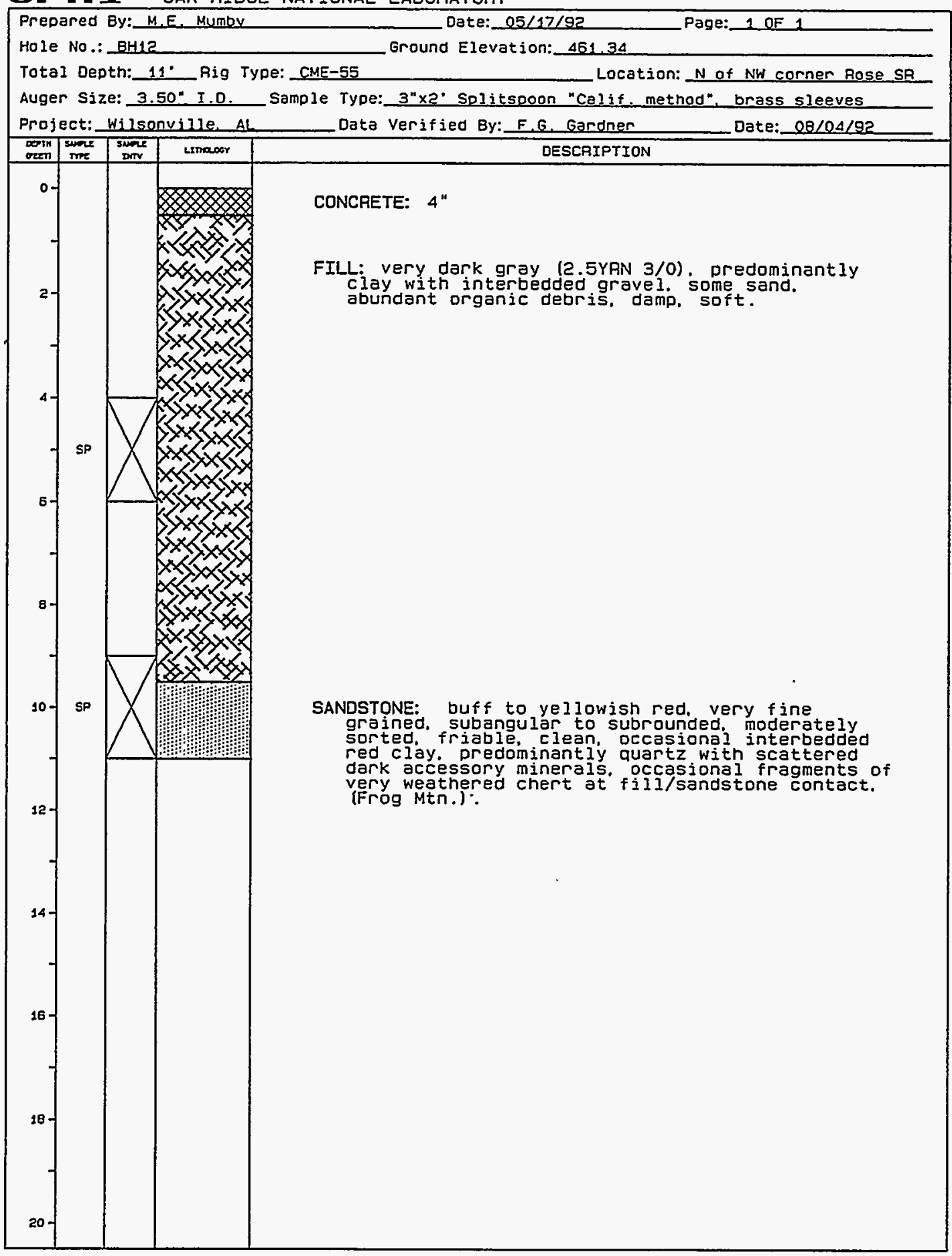


orn 1

Borehole Summary Information

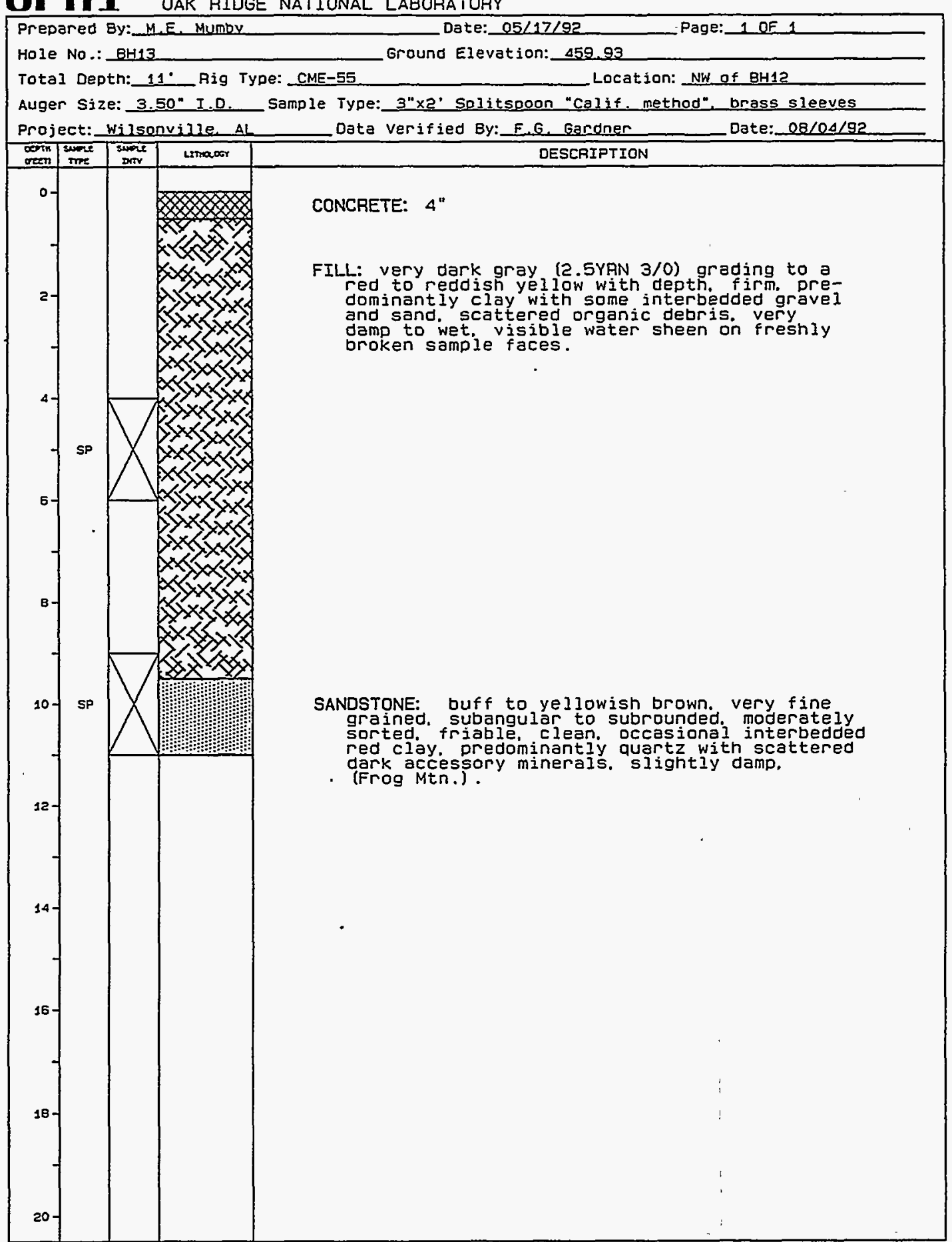


DII DaK RIDGE national LabORatory

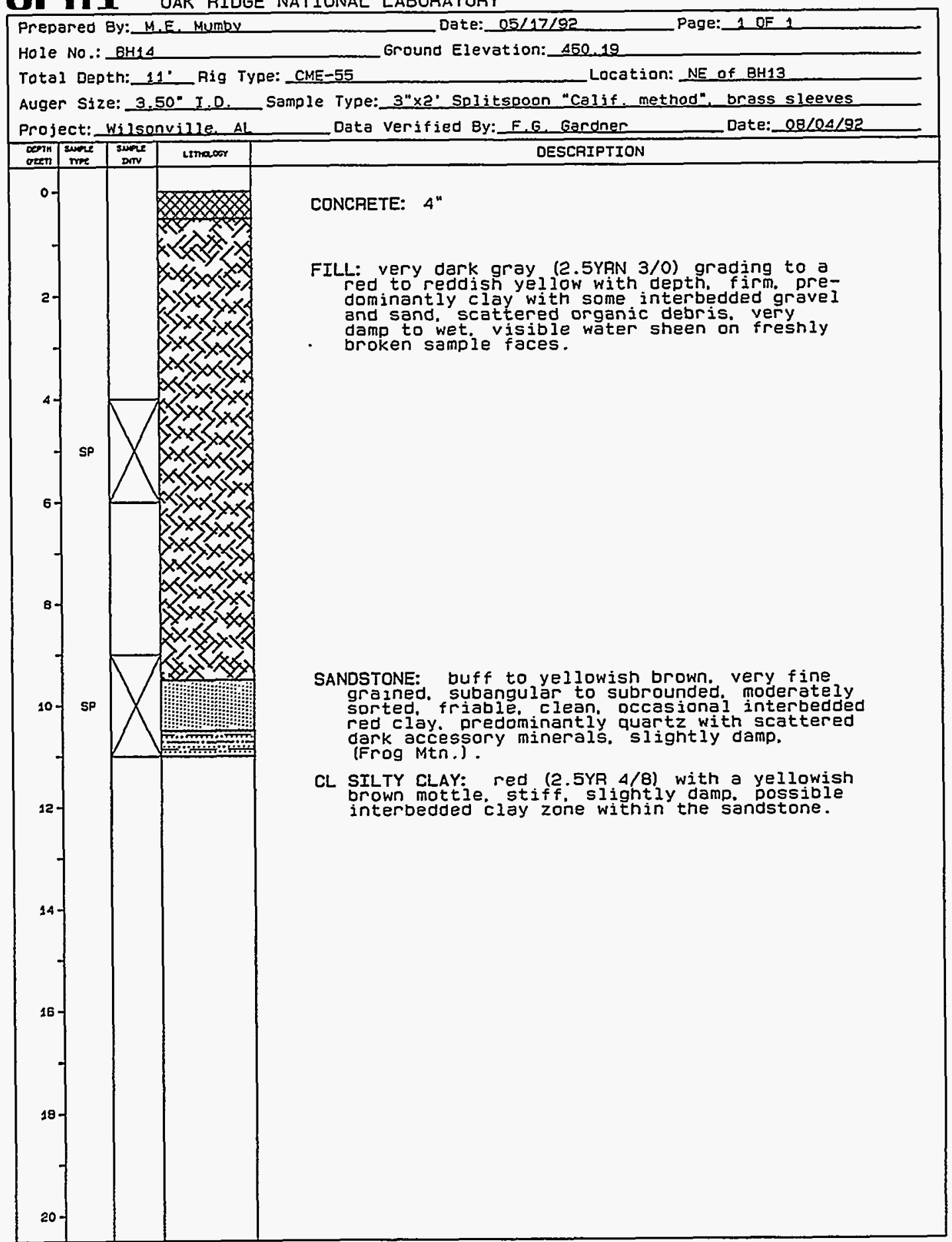


orn1

Borehole Summary Information

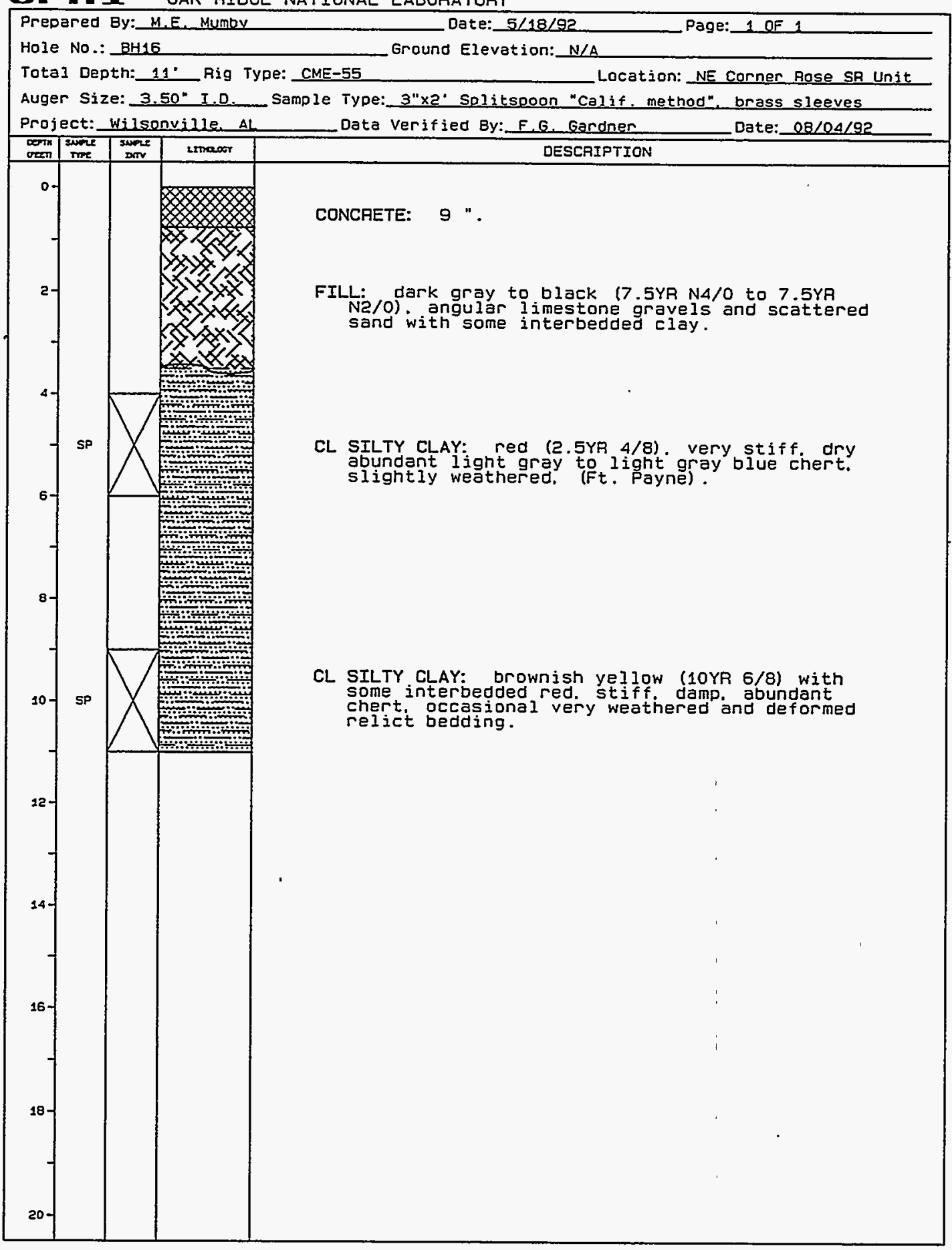


orn1

Borehole Summary Information

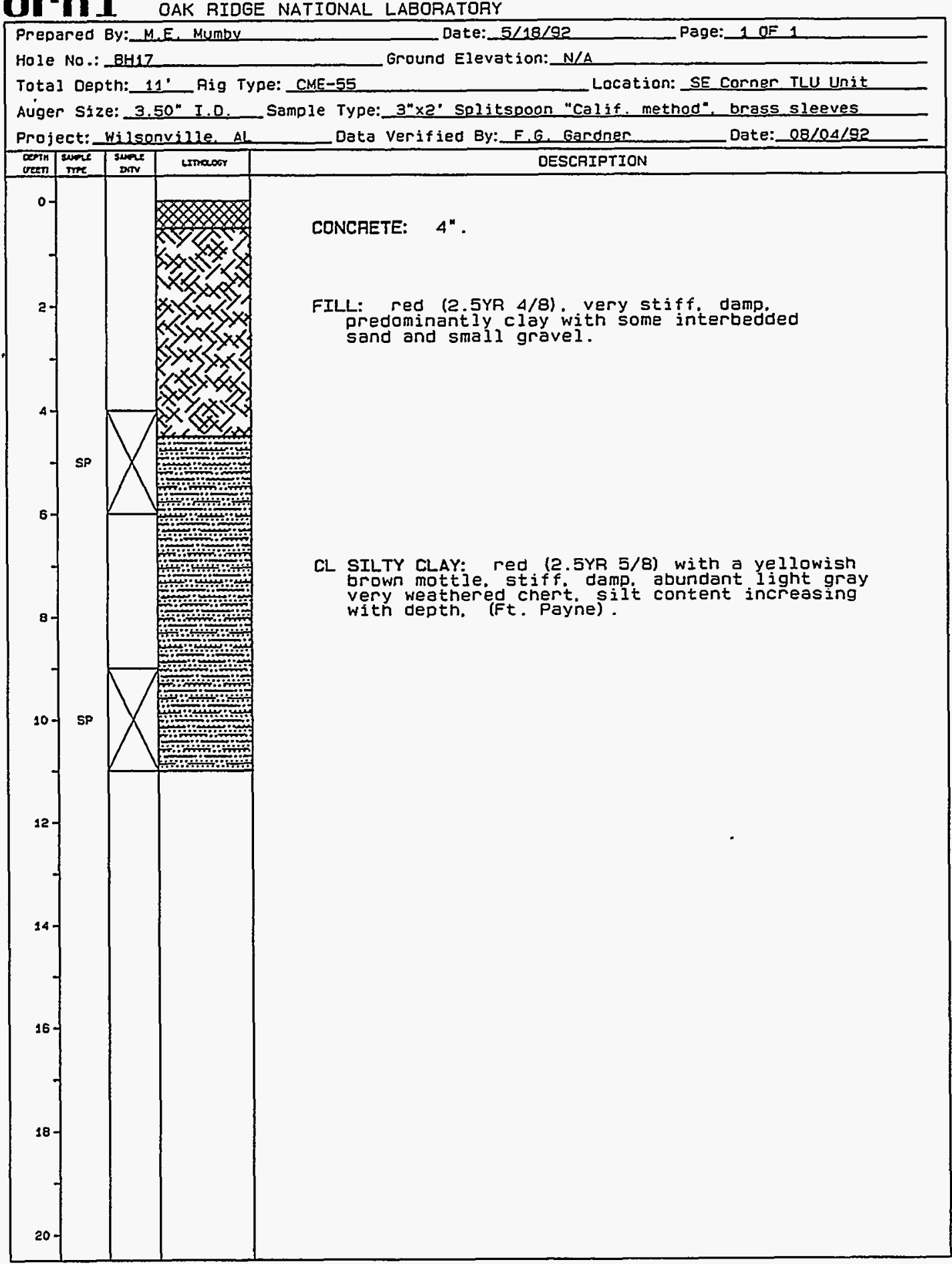


Orn 1 OAK RIDGE NATIONAL LABORATORY

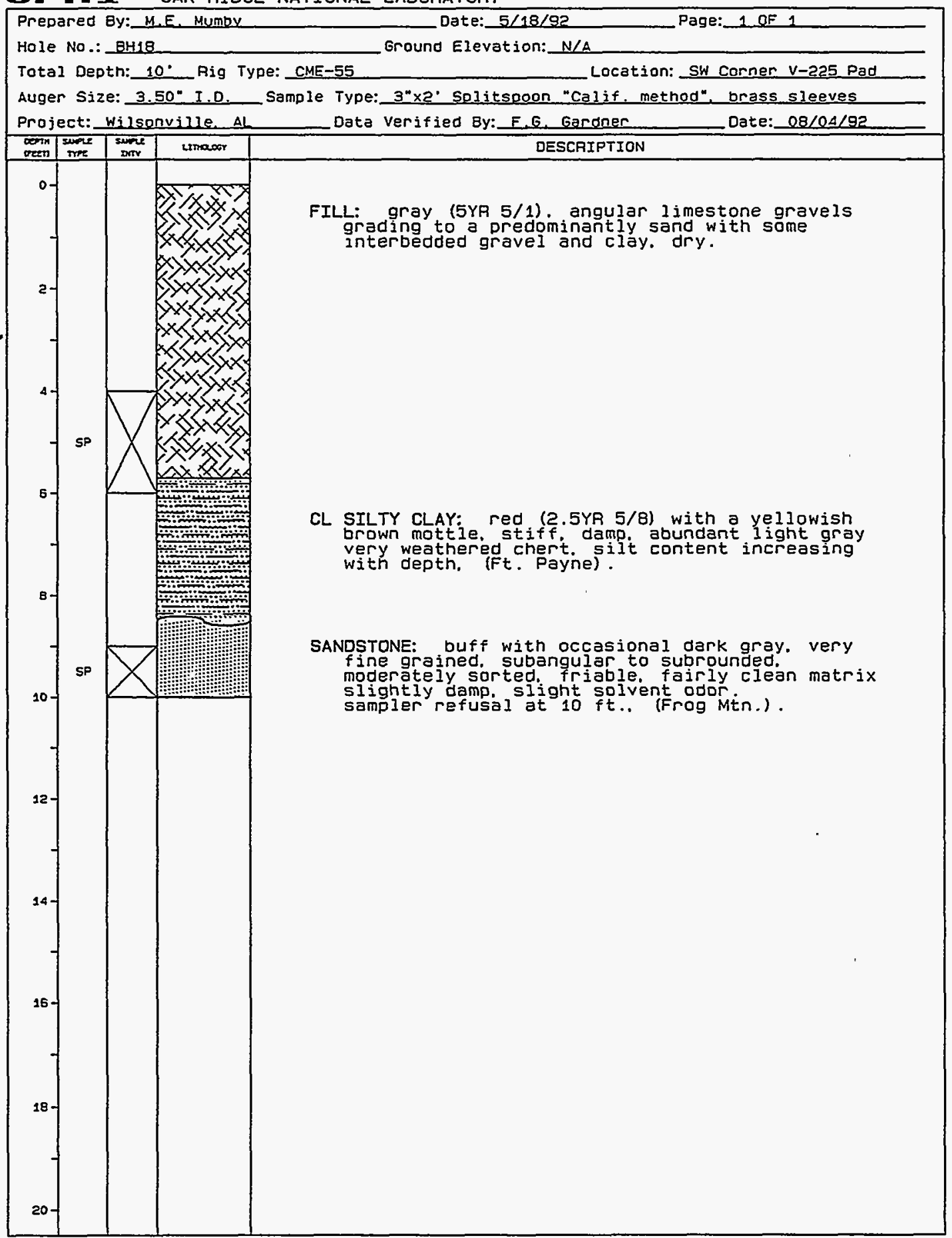


orn1

Borehole Summary Information

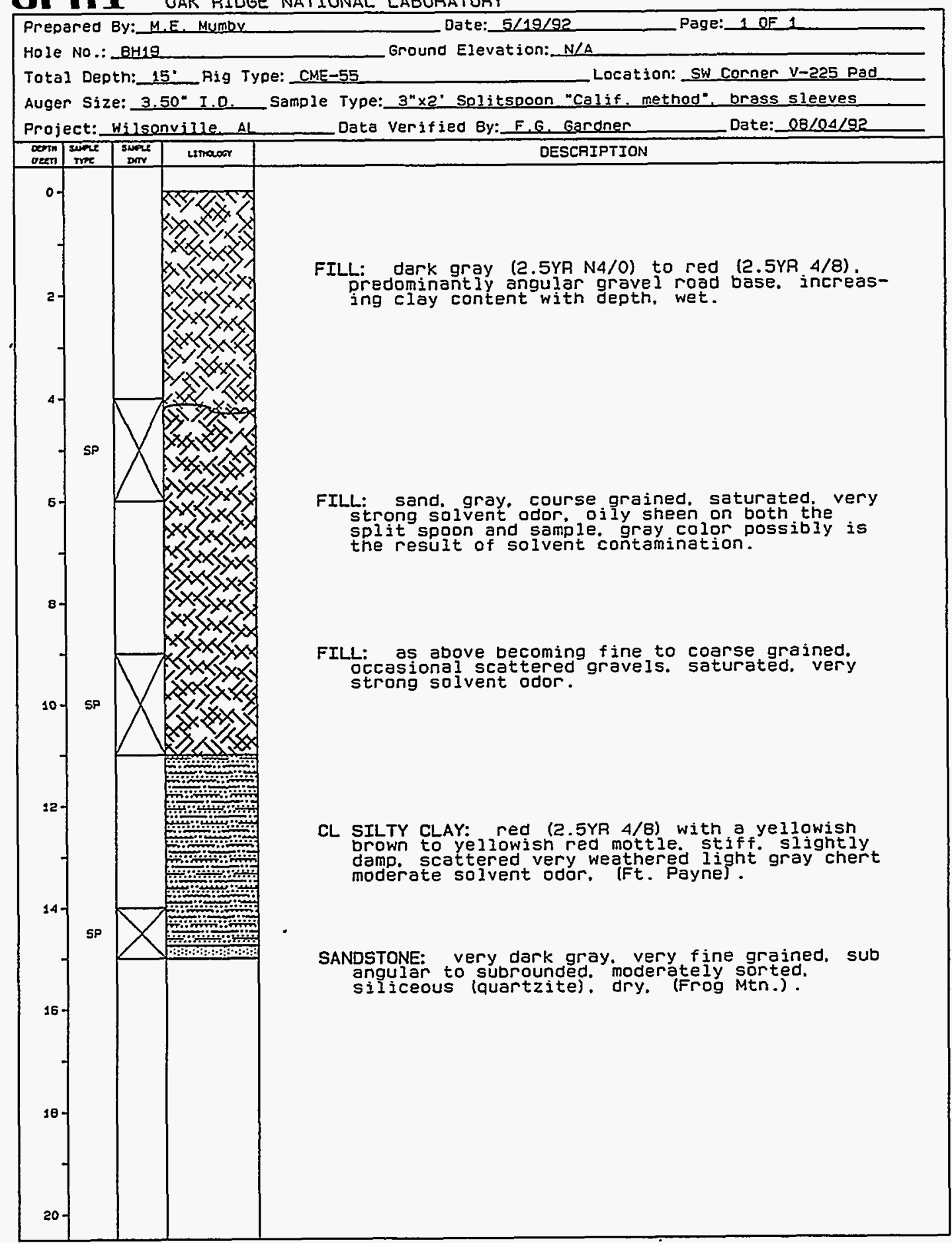


Orin] Borehole Summary. Information

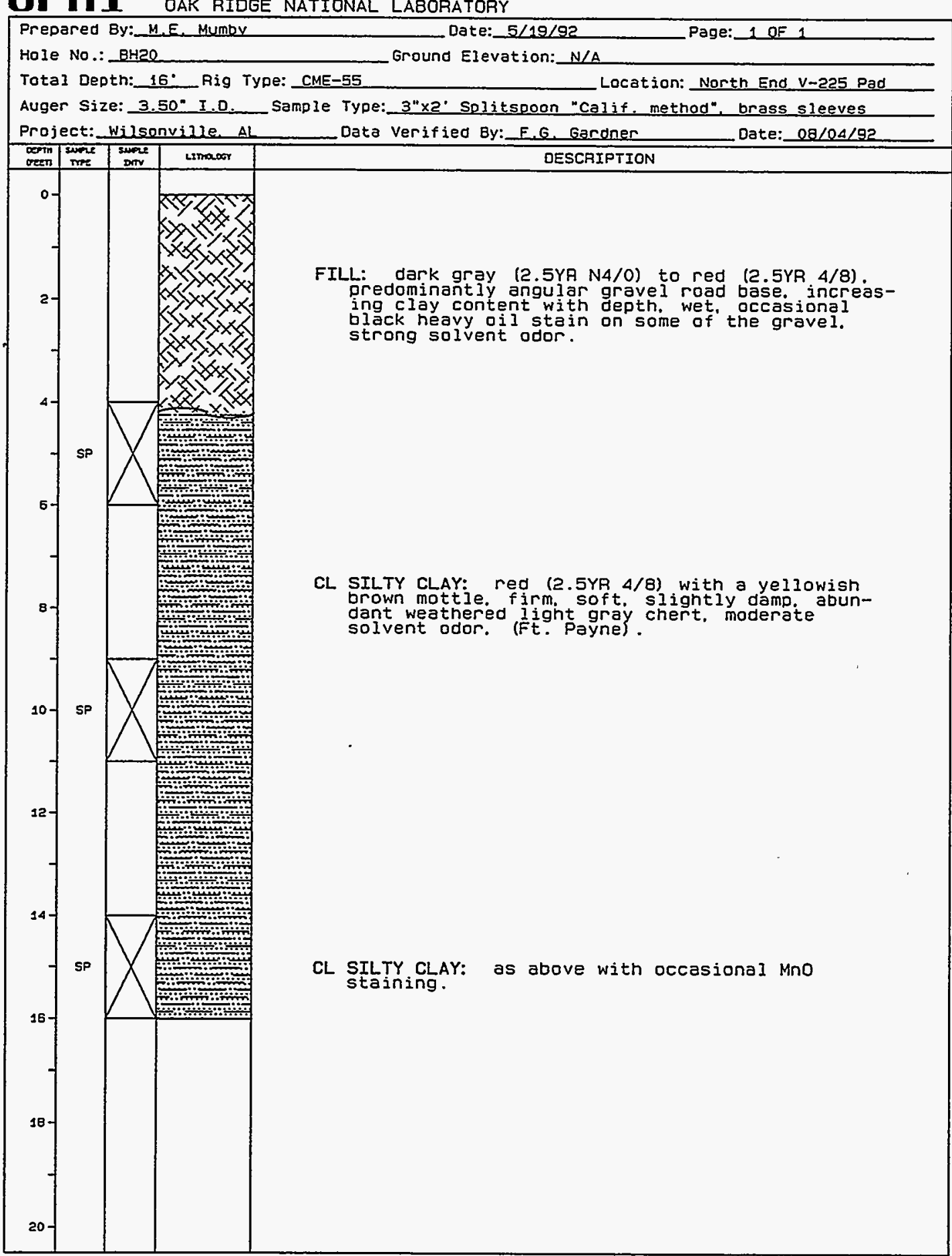


ar] Borehole Summary Information

I OAK RIDGE NATIONAL LABORATORY

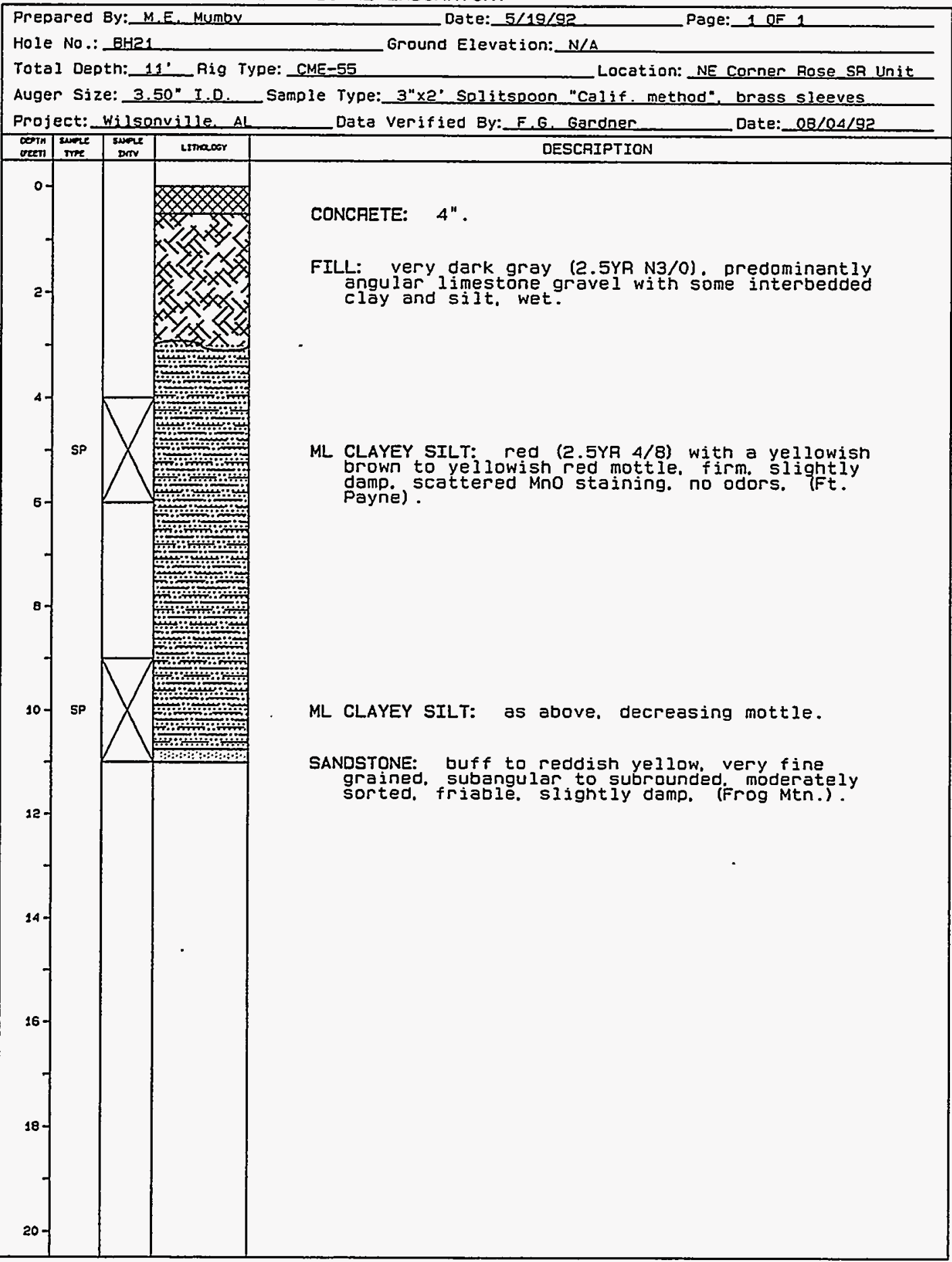


orn 1

Borehole Summary Information

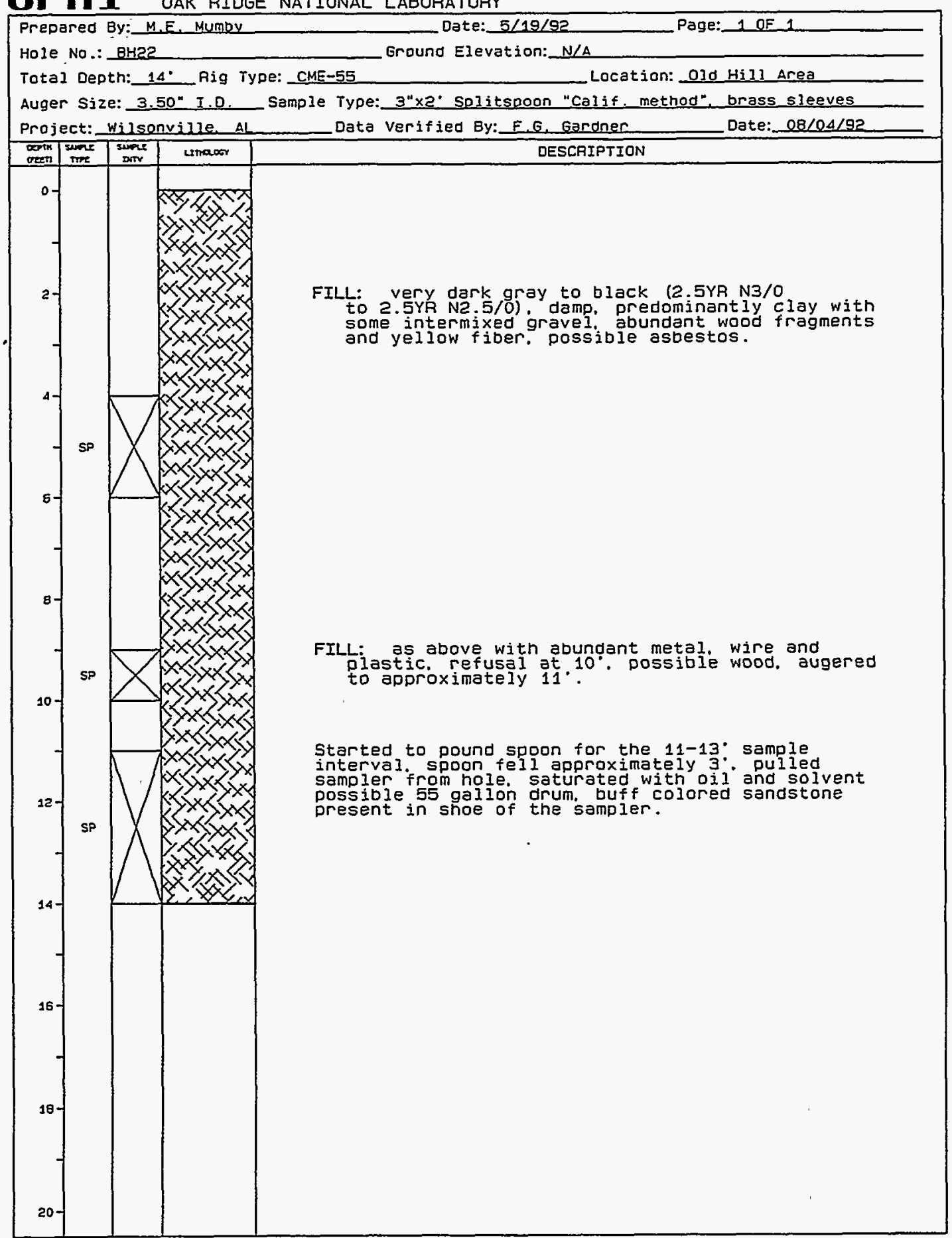


$\operatorname{arn} 1$

Borehole Summary Information

OAK RIDGE NATIONAL LABORATORY

Prepared By:_M.E Mumby Oate: $5 / 19 / 92$

Ground Elevation: $N /$

Hole No.: $\frac{\mathrm{BH} 23}{\text { Total Depth: 11' Rig Type: CME-55 }}$

Auger Size: $30^{\circ}$ T

Project: Wilsonville. AL__ Data Verified By: F,G. Gardner

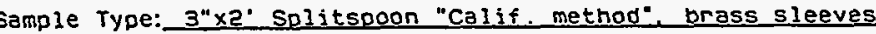

Date: $08 / 04 / 92$

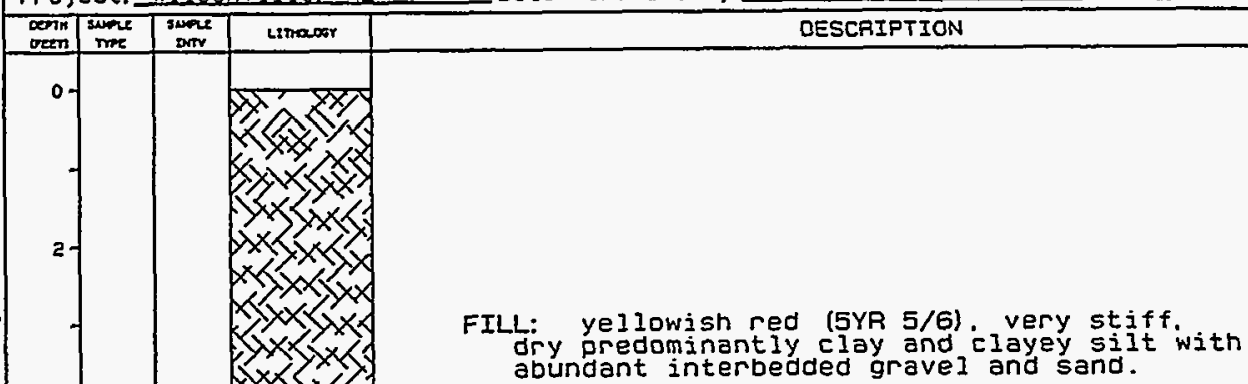

abundant interbedded gravel and sand.

SHALE: reddish brown, very weathered fissile.

occasional Mno staining. no odors. (Floyd

Shale). 
OrII OAK RIDGE NATIONAL LABORATORY

Borehole Summary Information

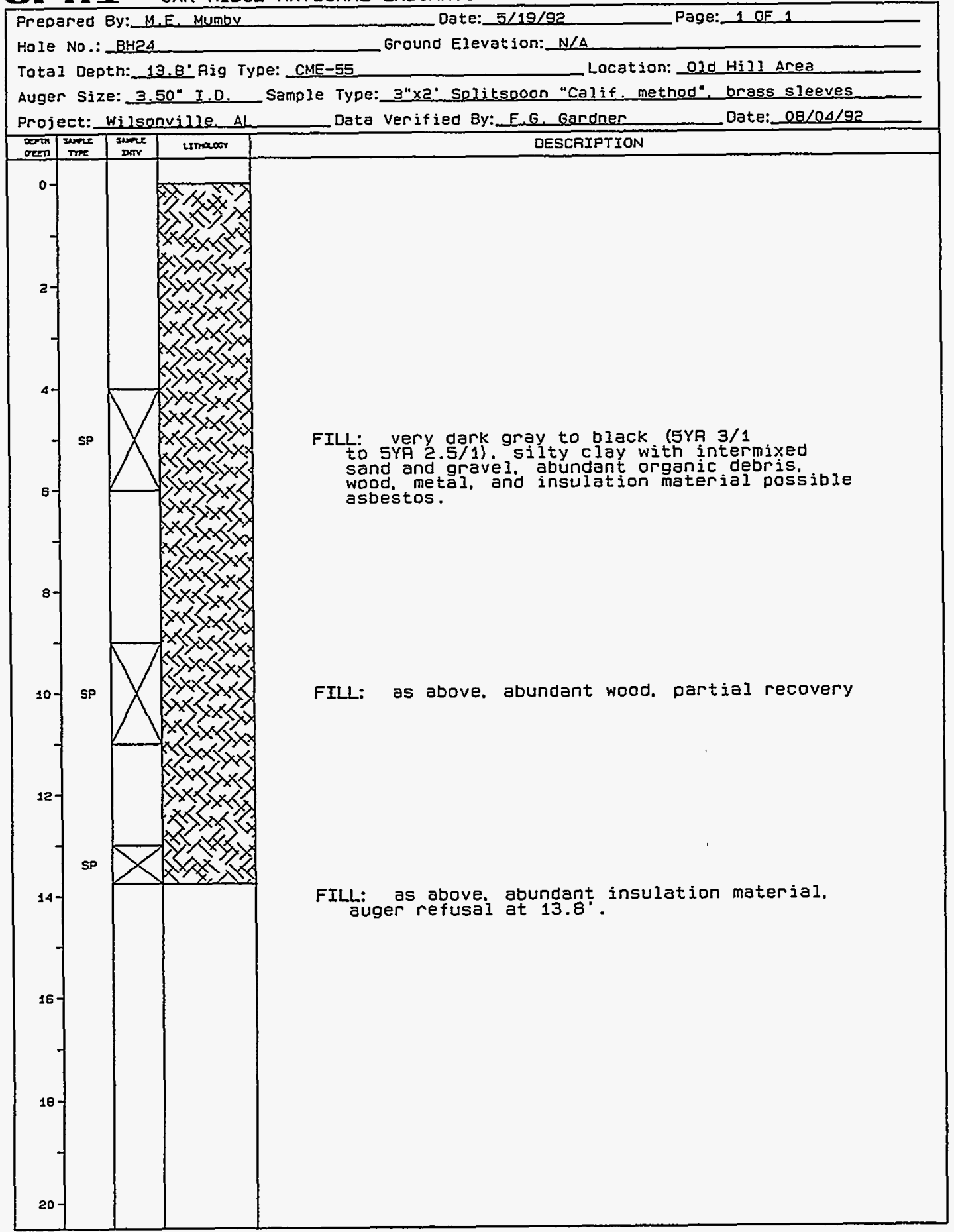


orn 1

Borehole Summary Information

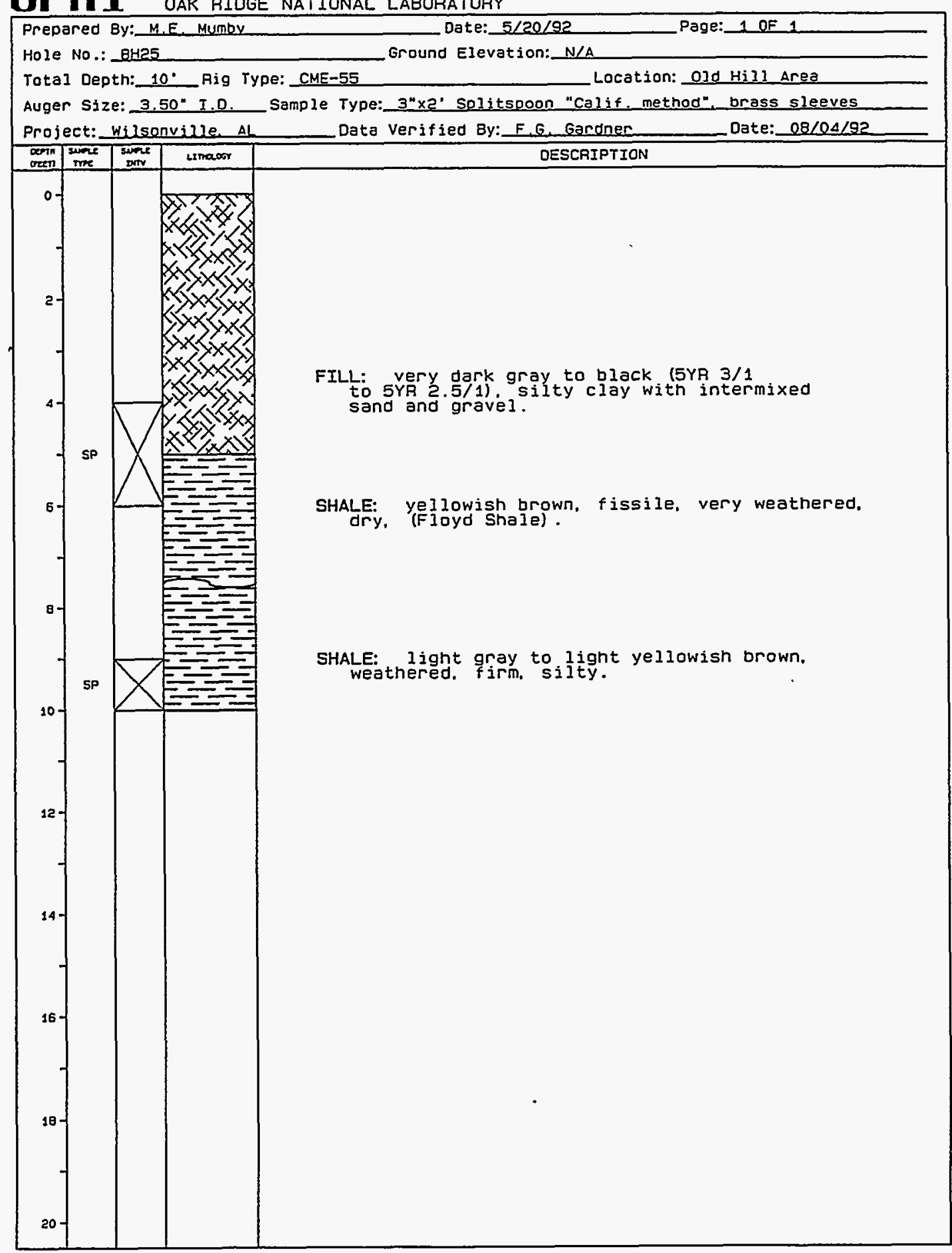


DI] 1 Borehole Summary Information

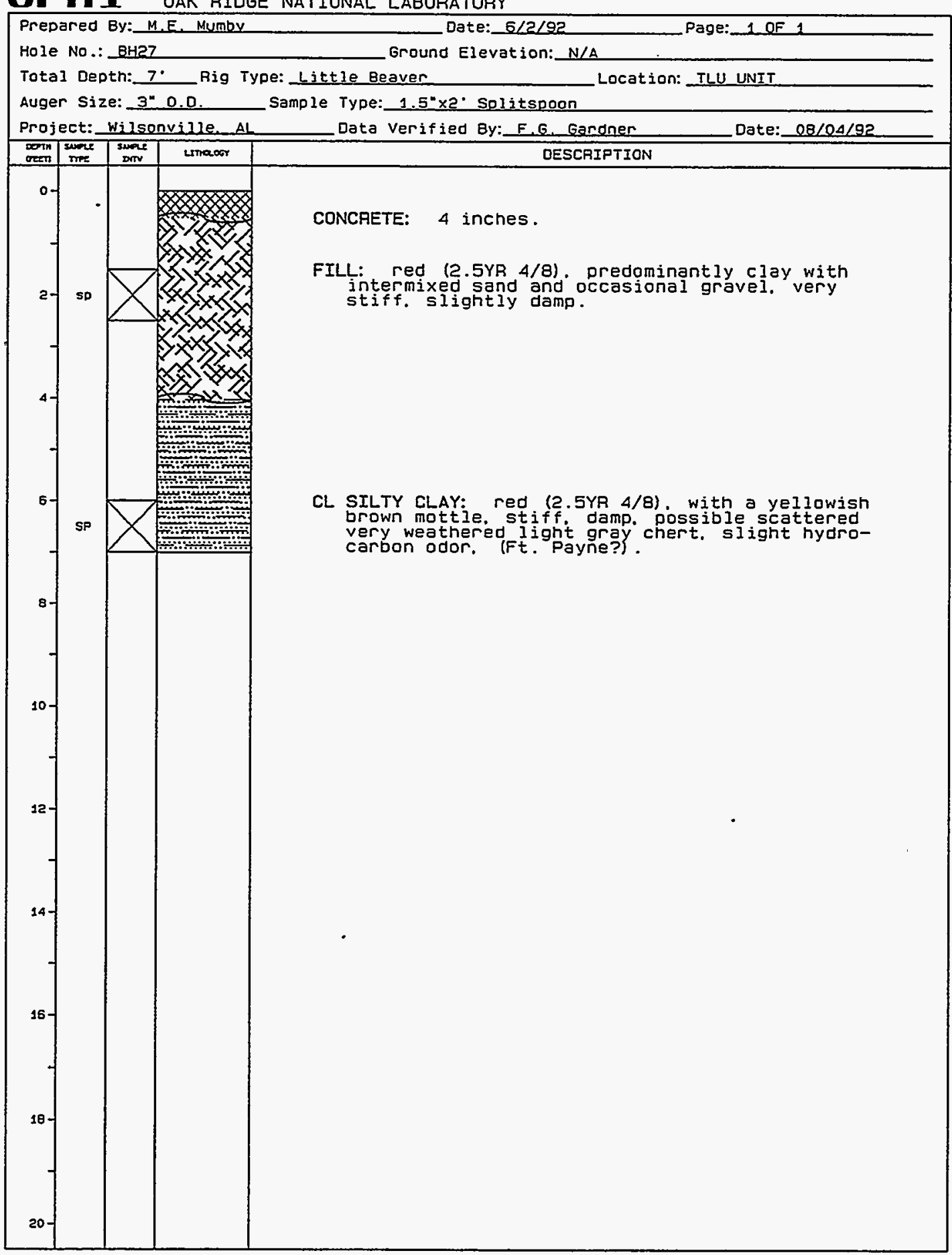


orn 1

Borehole Summary Information

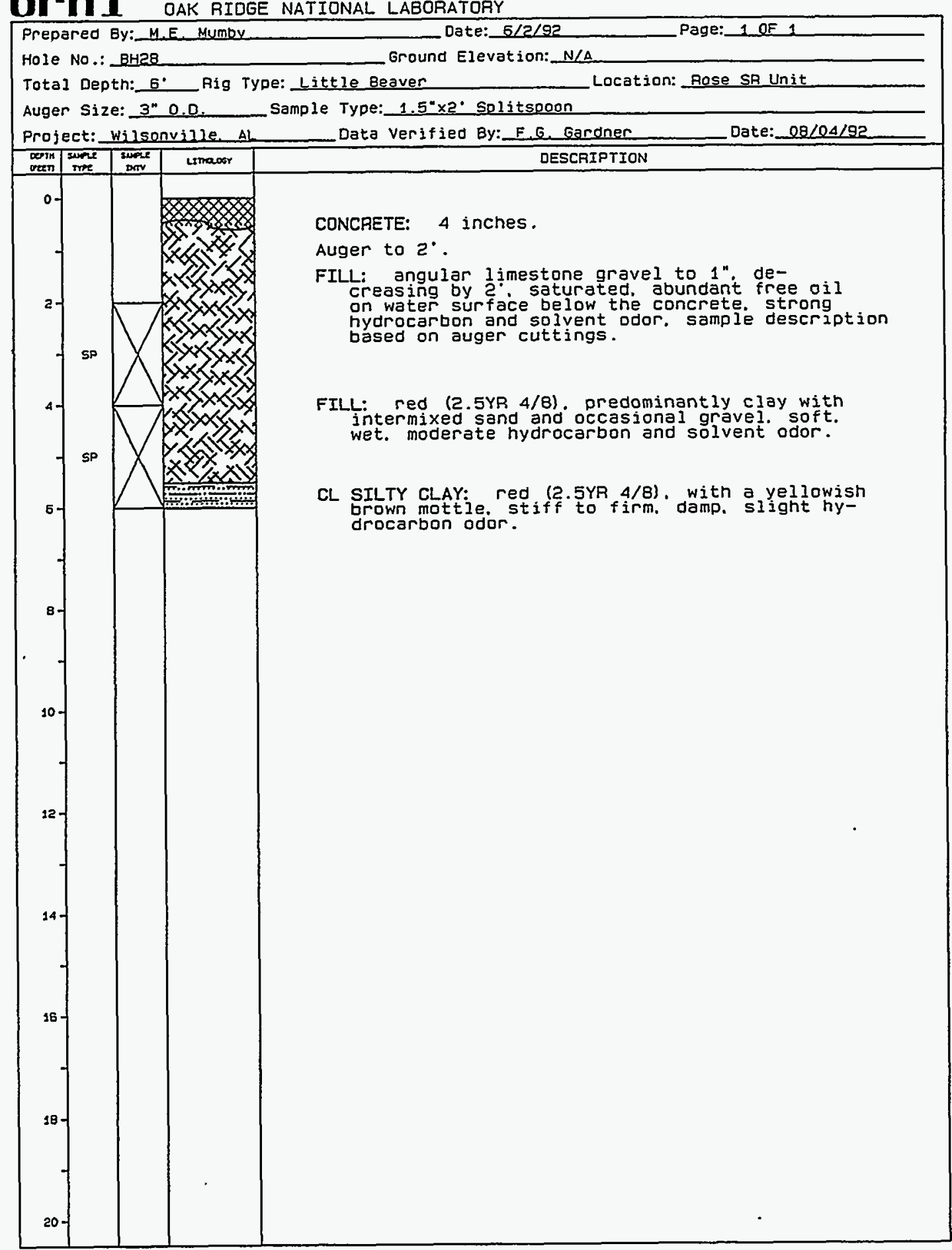


orn 1

Borehole Summary Information

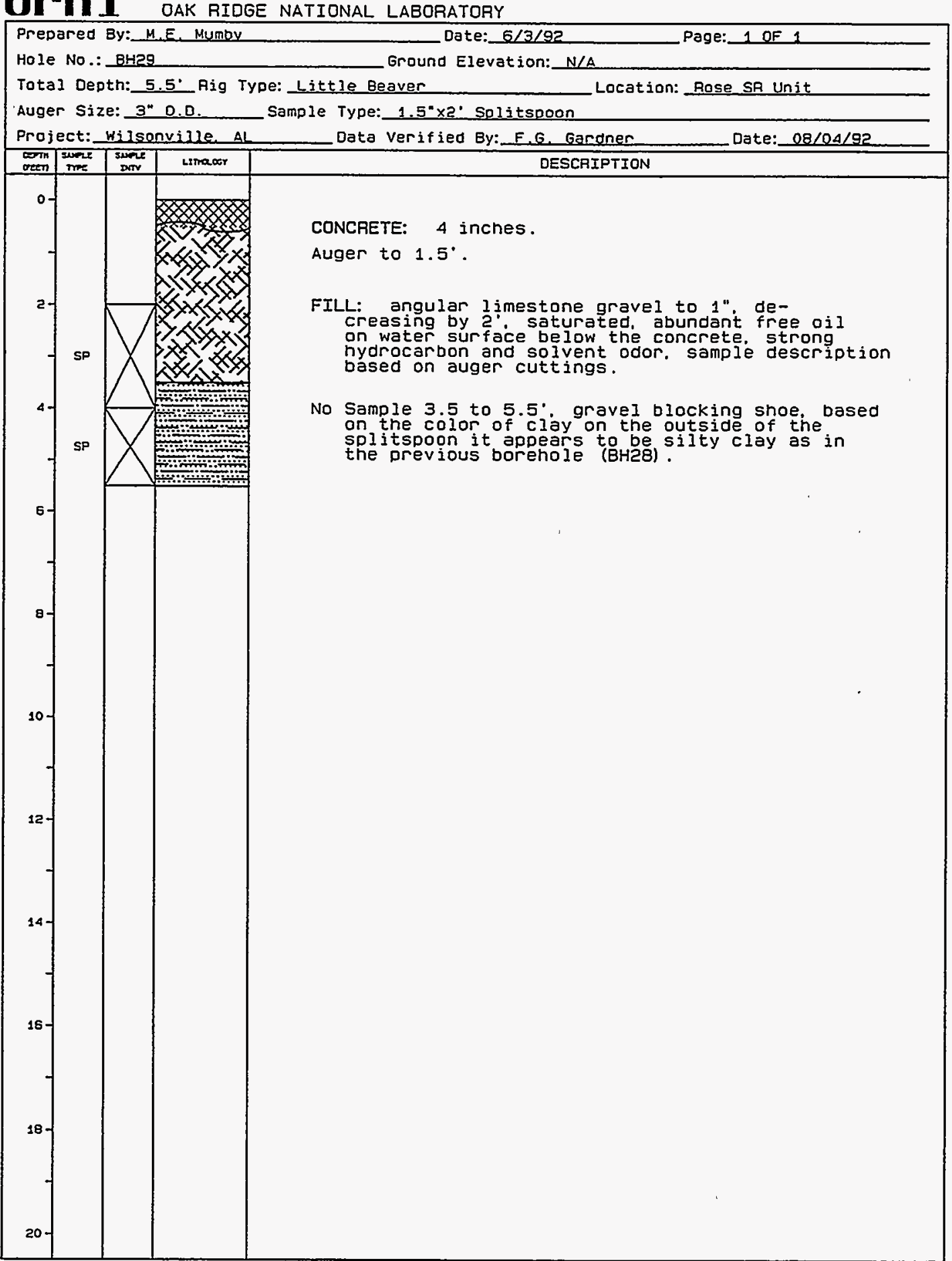




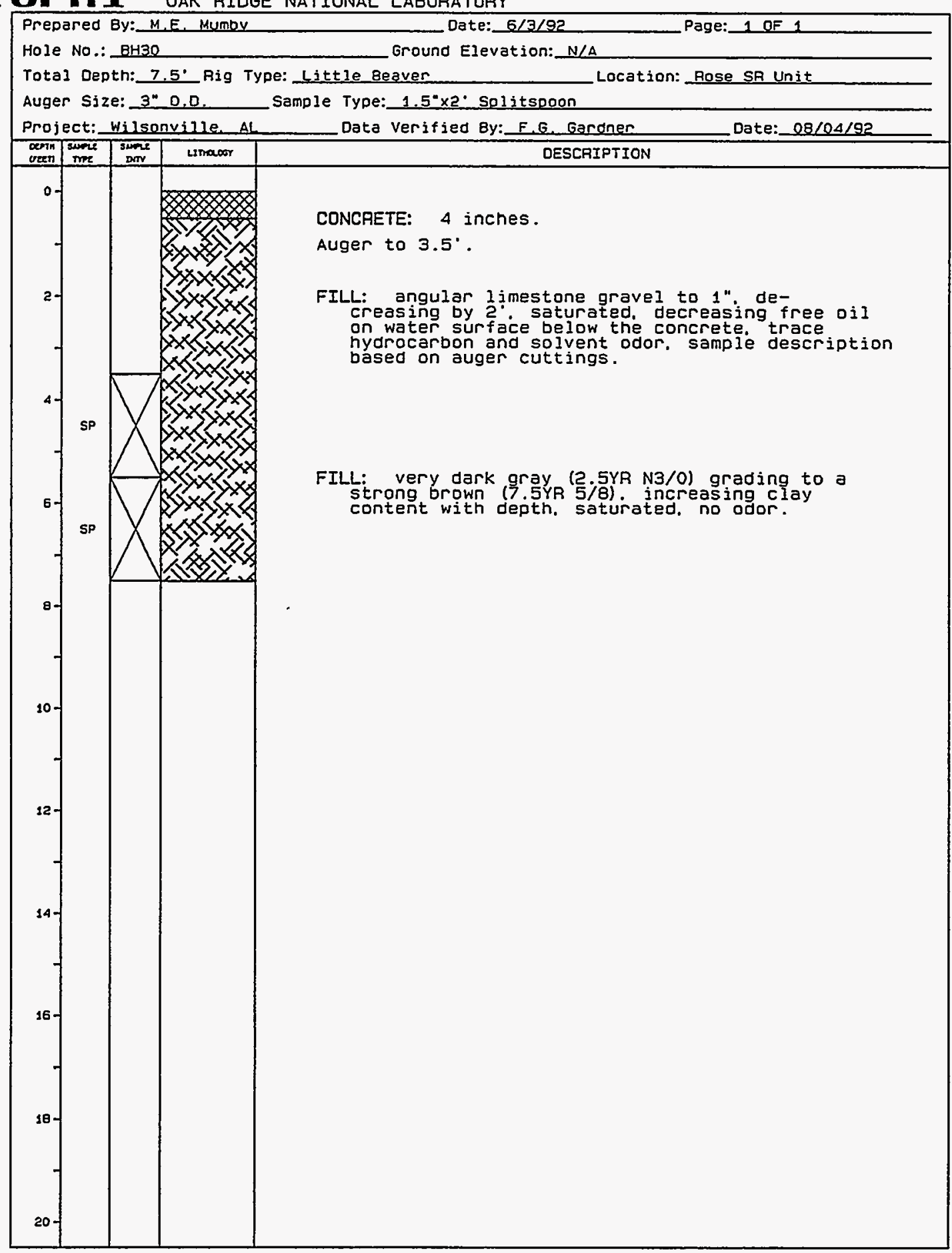


orn 1

Borehole Summary Information

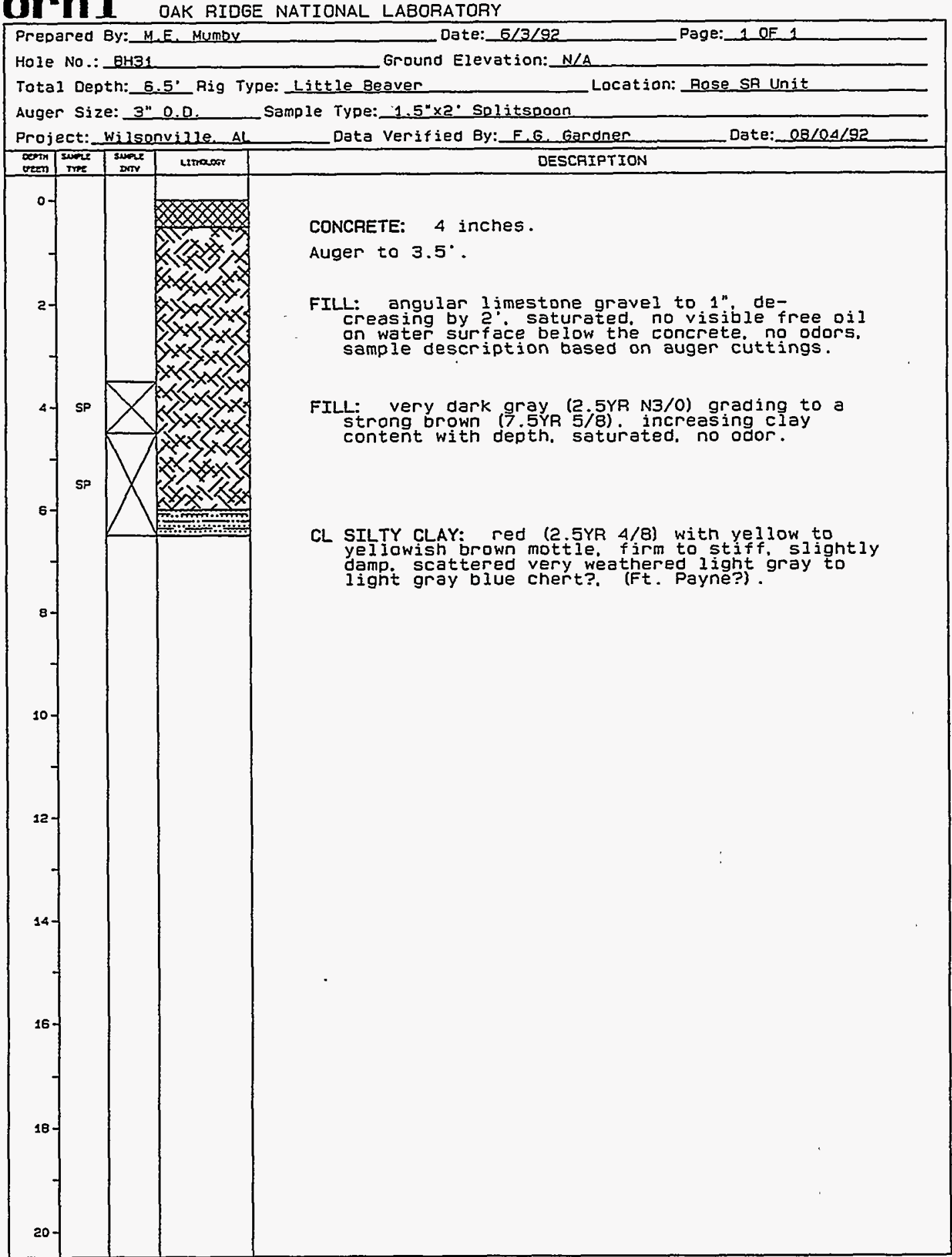


arn] Borehole Summary Information

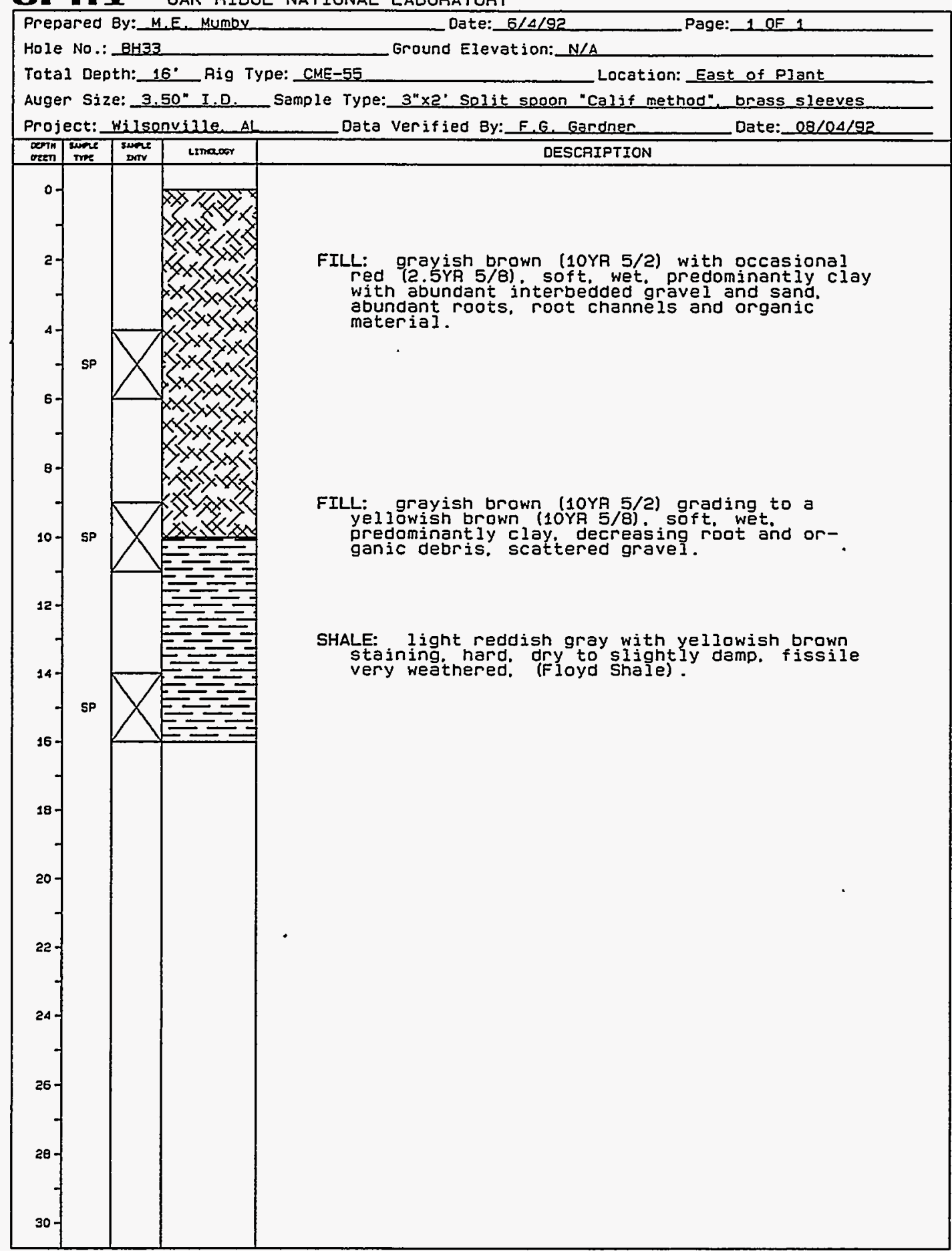


ornl

Borehole Summary Information

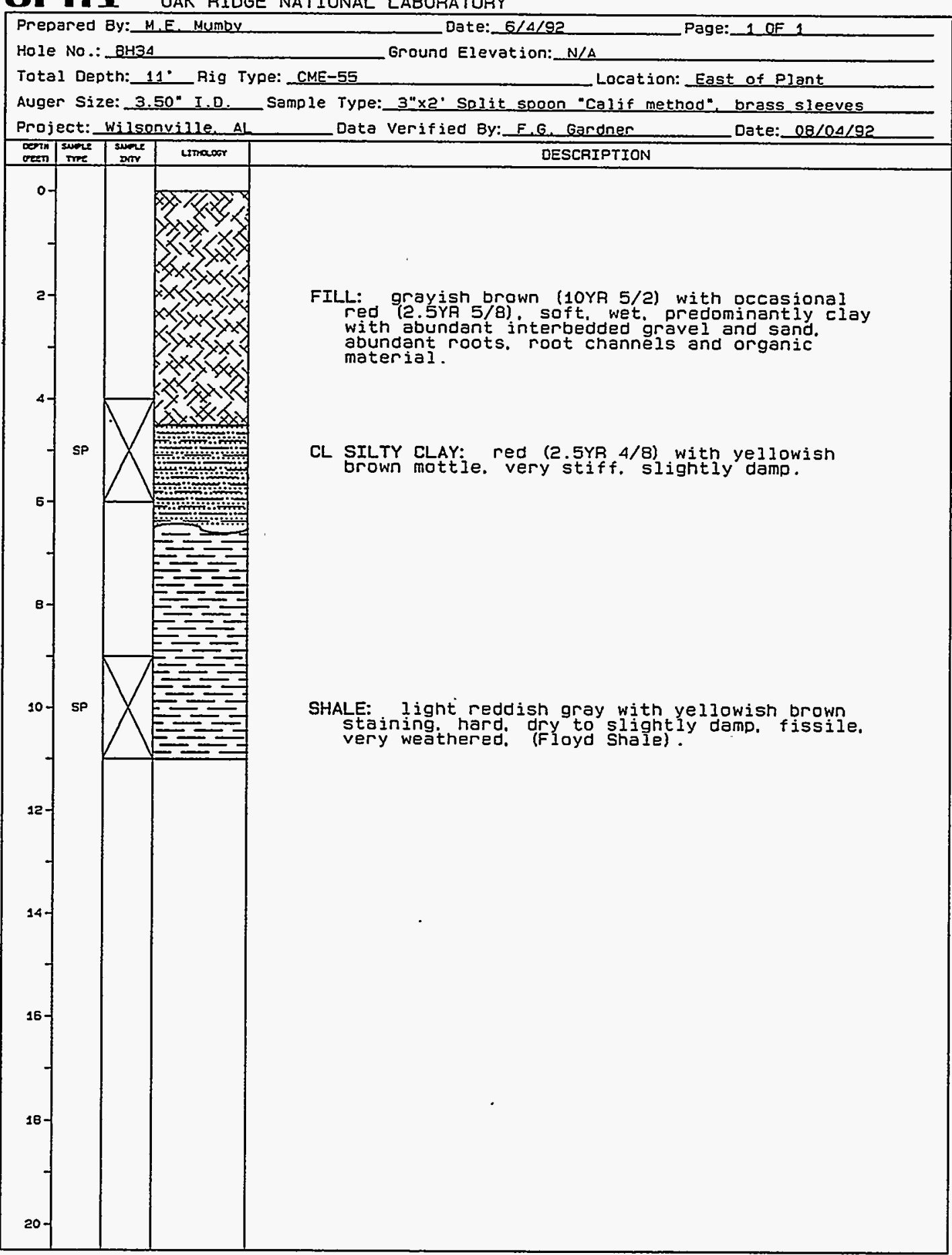




\section{OrnI oak bidge national Laboratory}

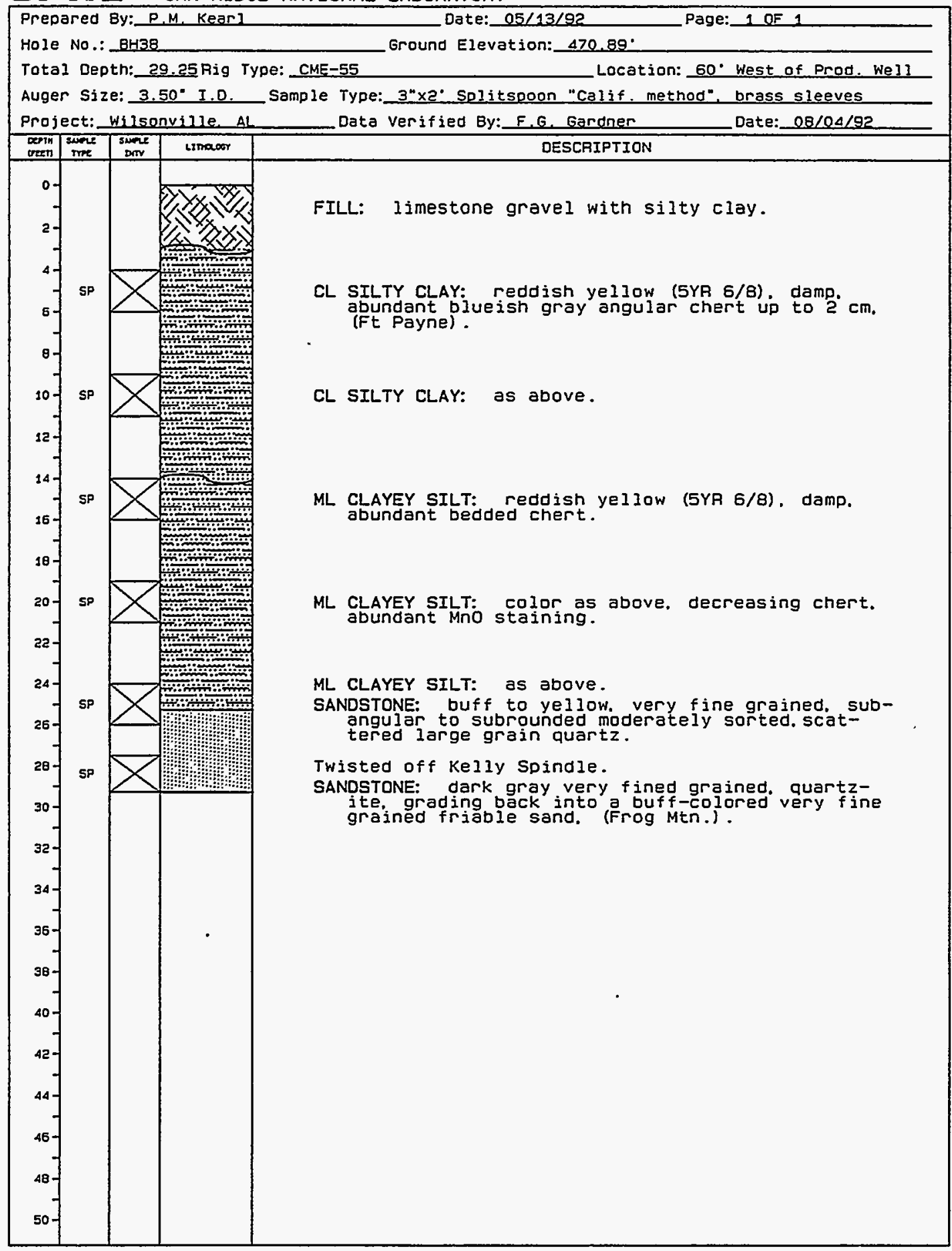


QTI OAK RIDGE NATIONAL LABORATORY

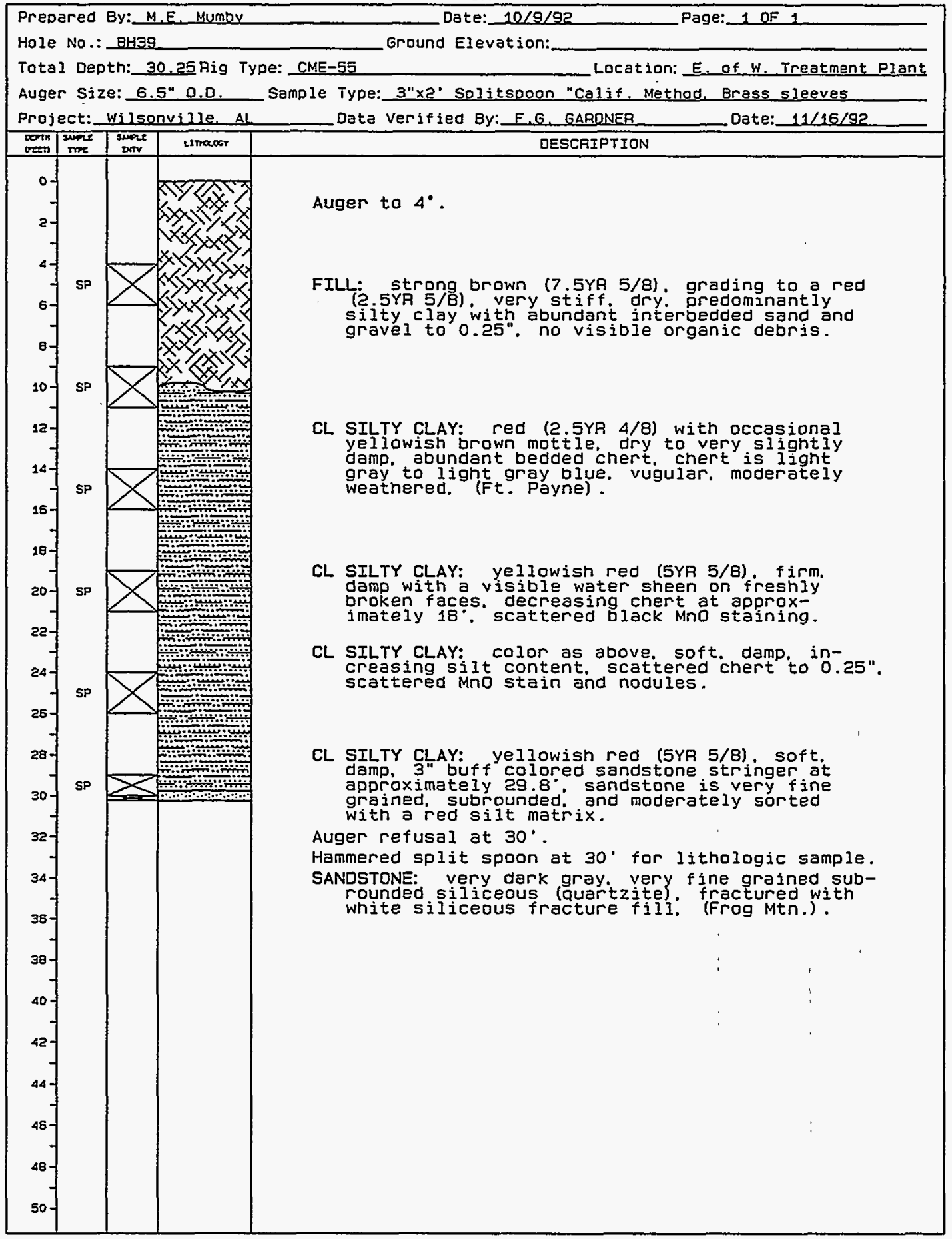


arn 1 oak RIDGE national Laboratory

Borehole Summary Information

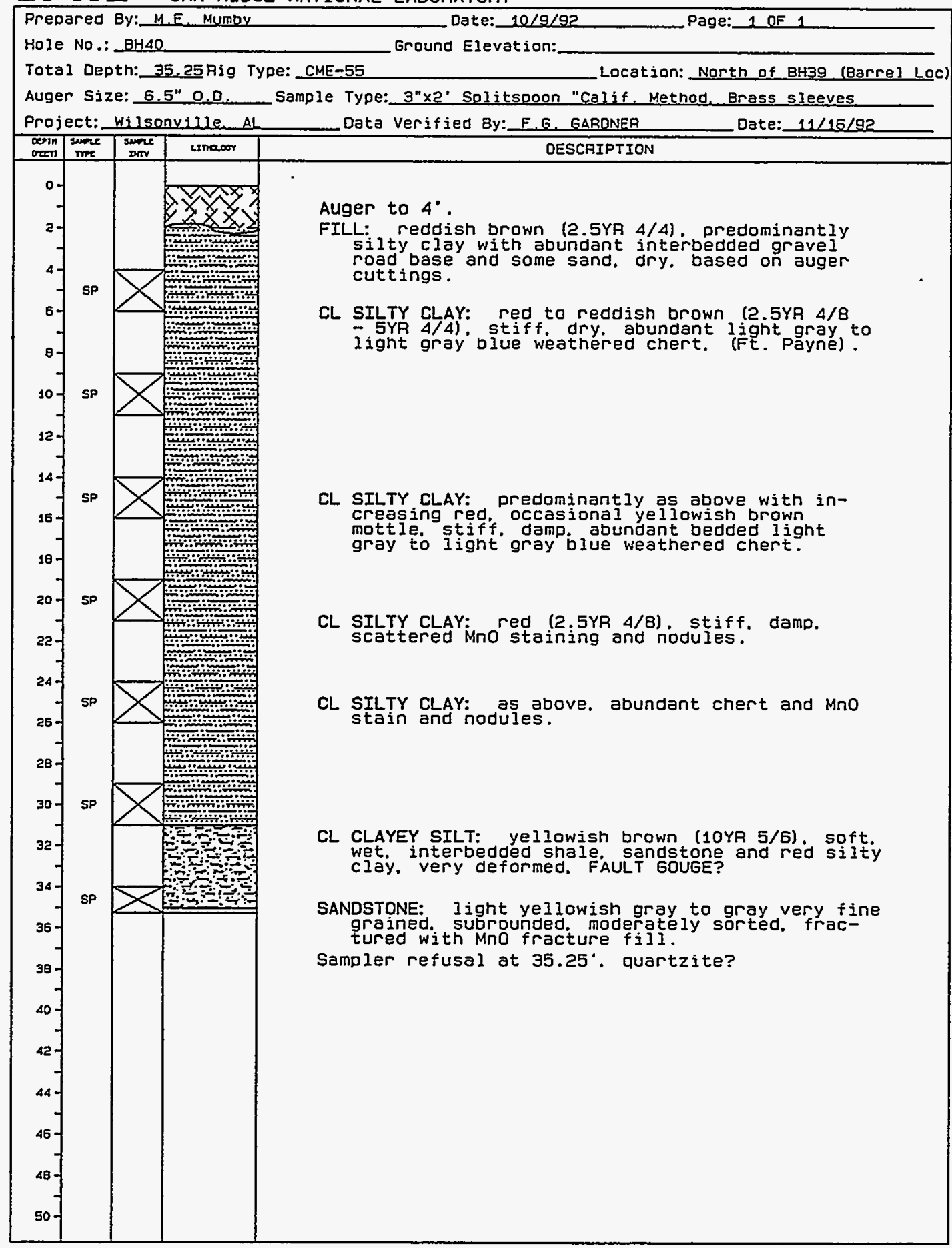


Borehole Summary Information

QII DaK RIDGE NATIONAL LabÓRATORY

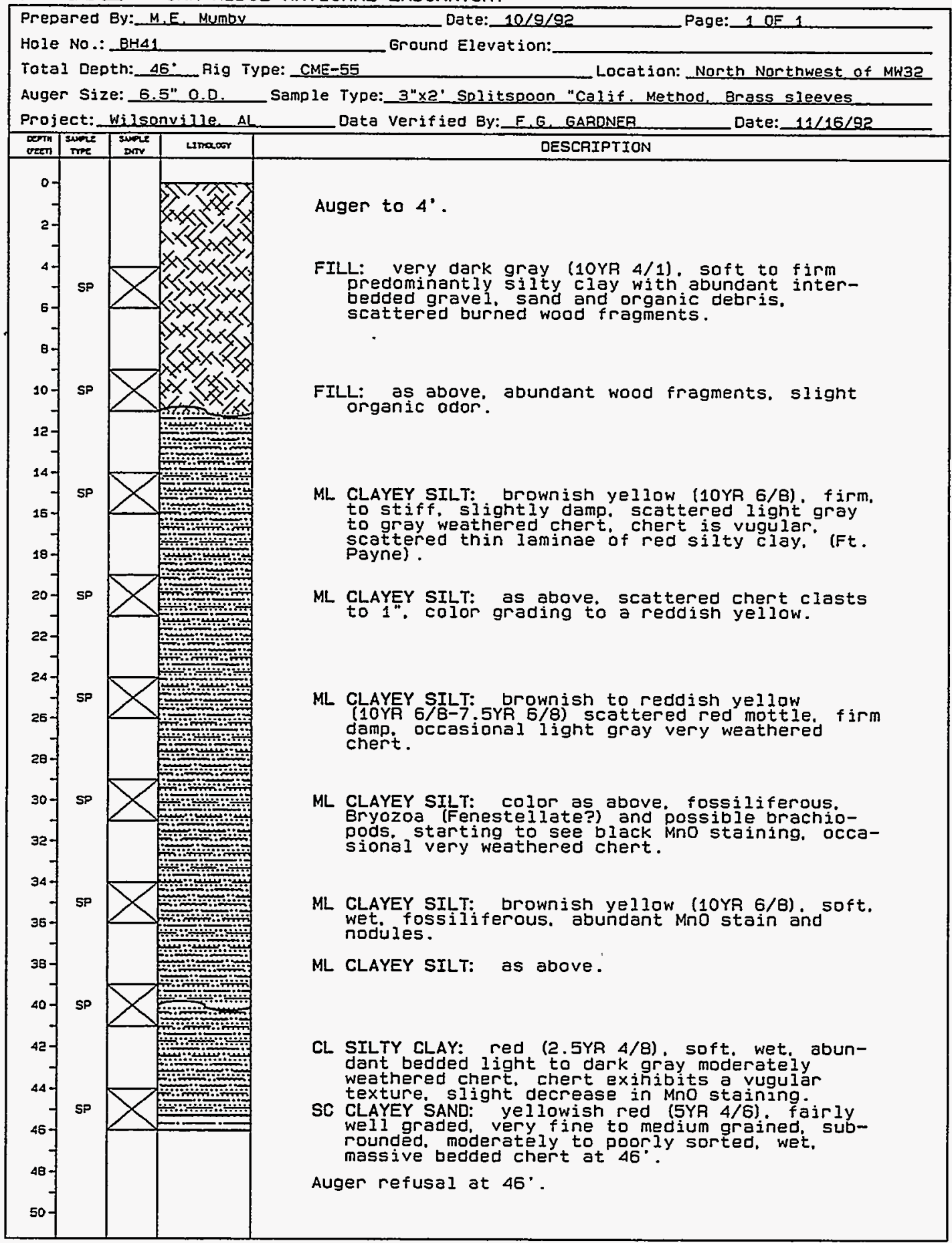


orn 1

Borehole Summary Information

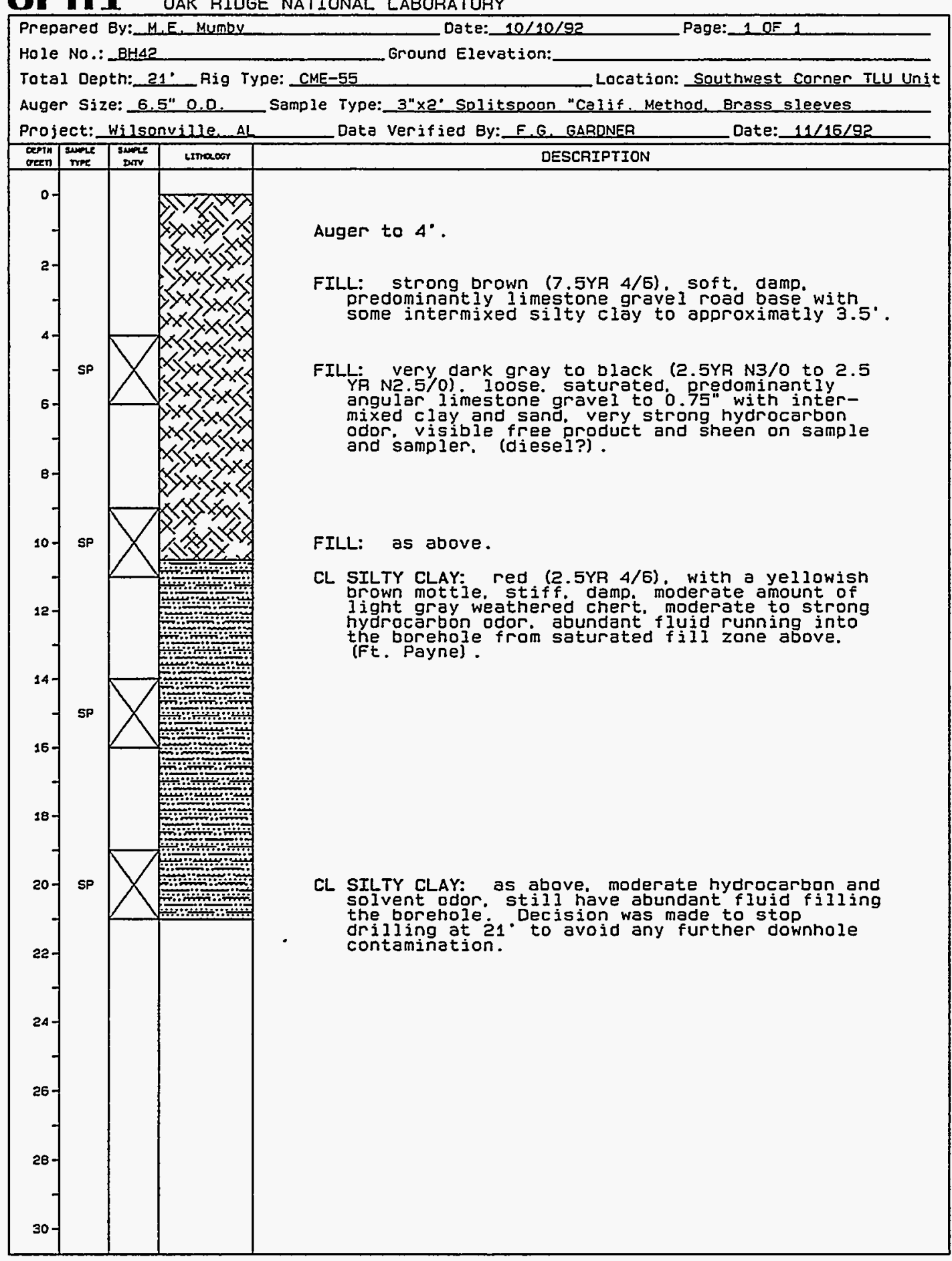


ar] Borehole Summary Information

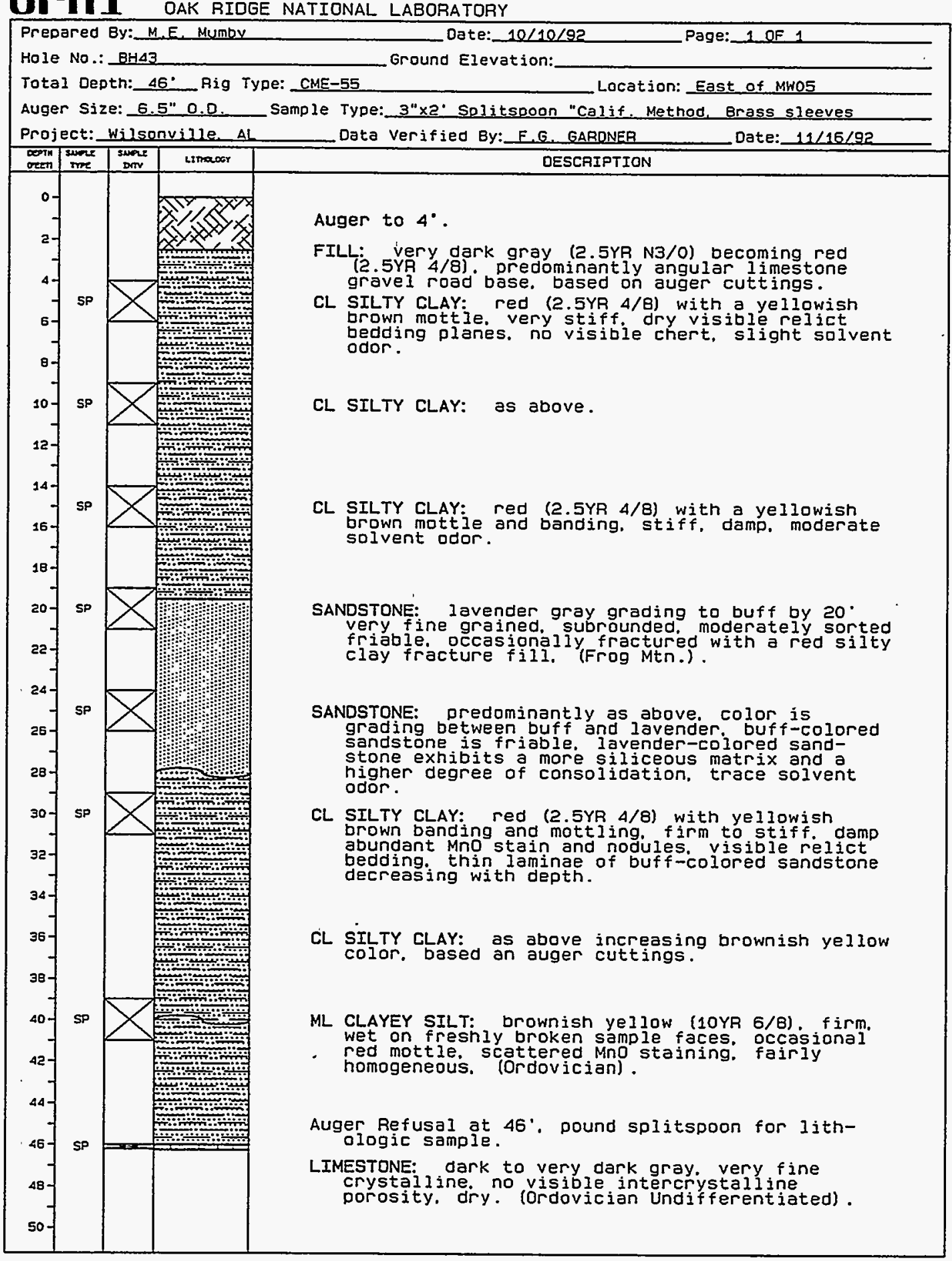




\section{arn1 OAK RIDGE NATIONAL LABORATORY}

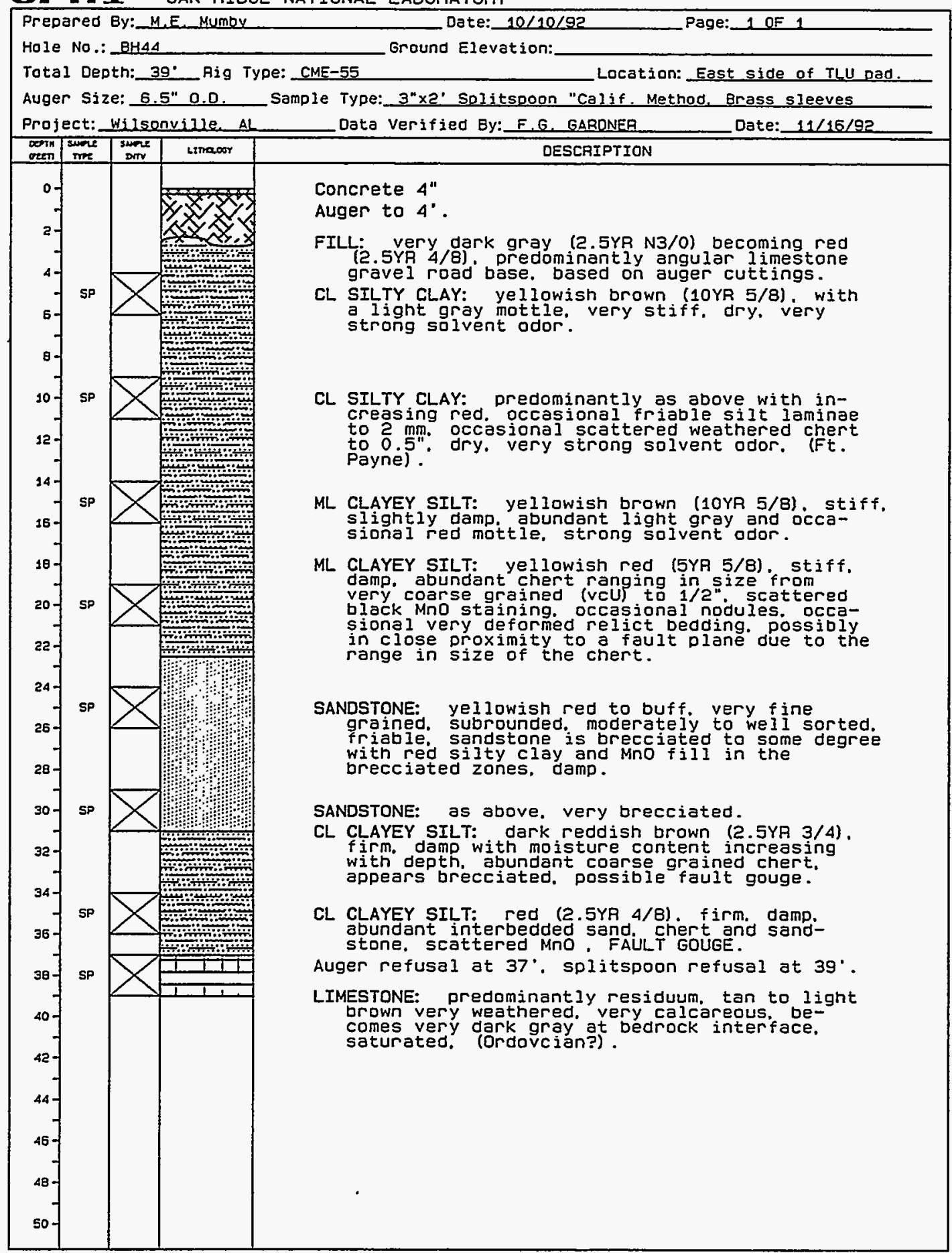


0[I] Borehole Summary Information

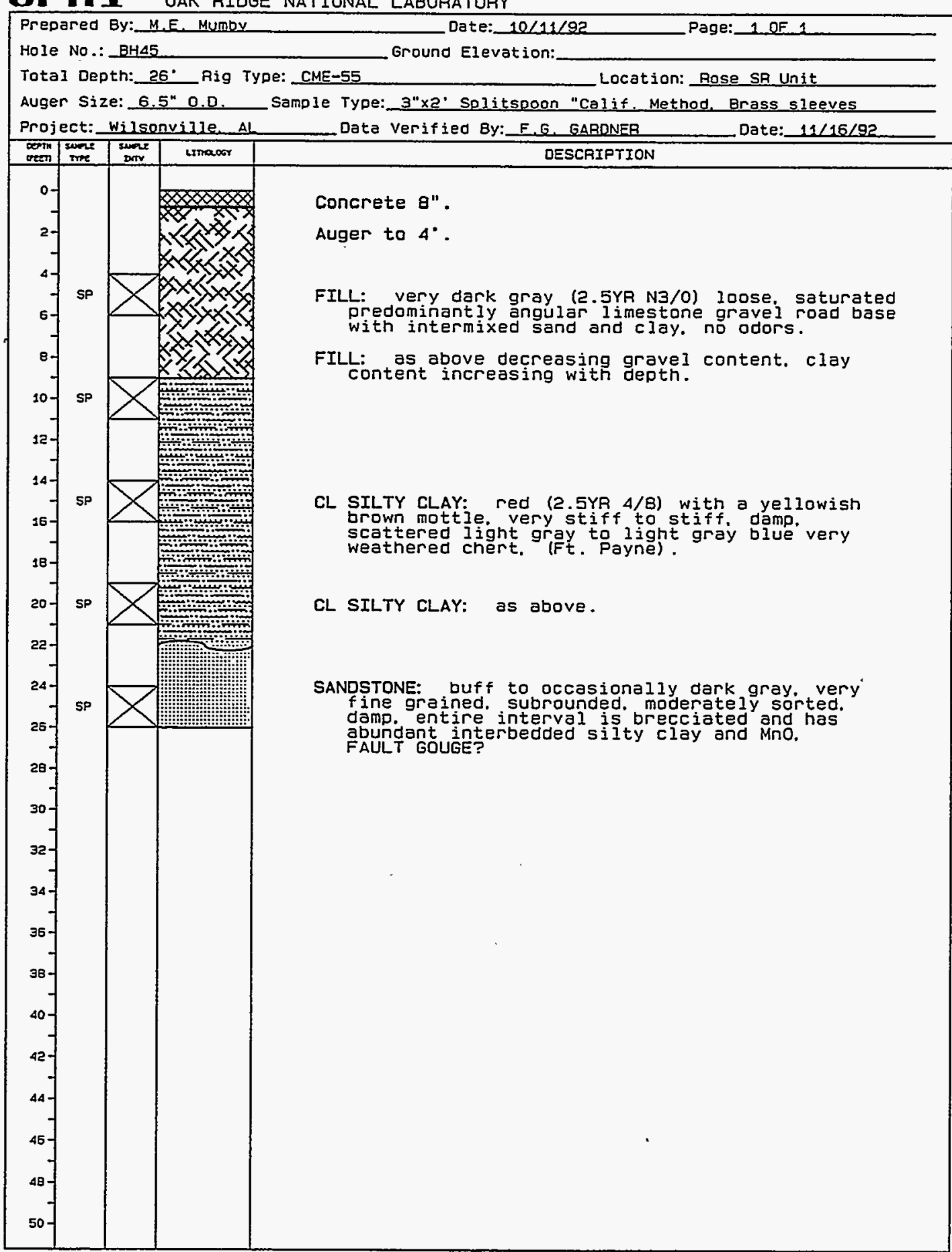


orn 1

Borehole Summary Information

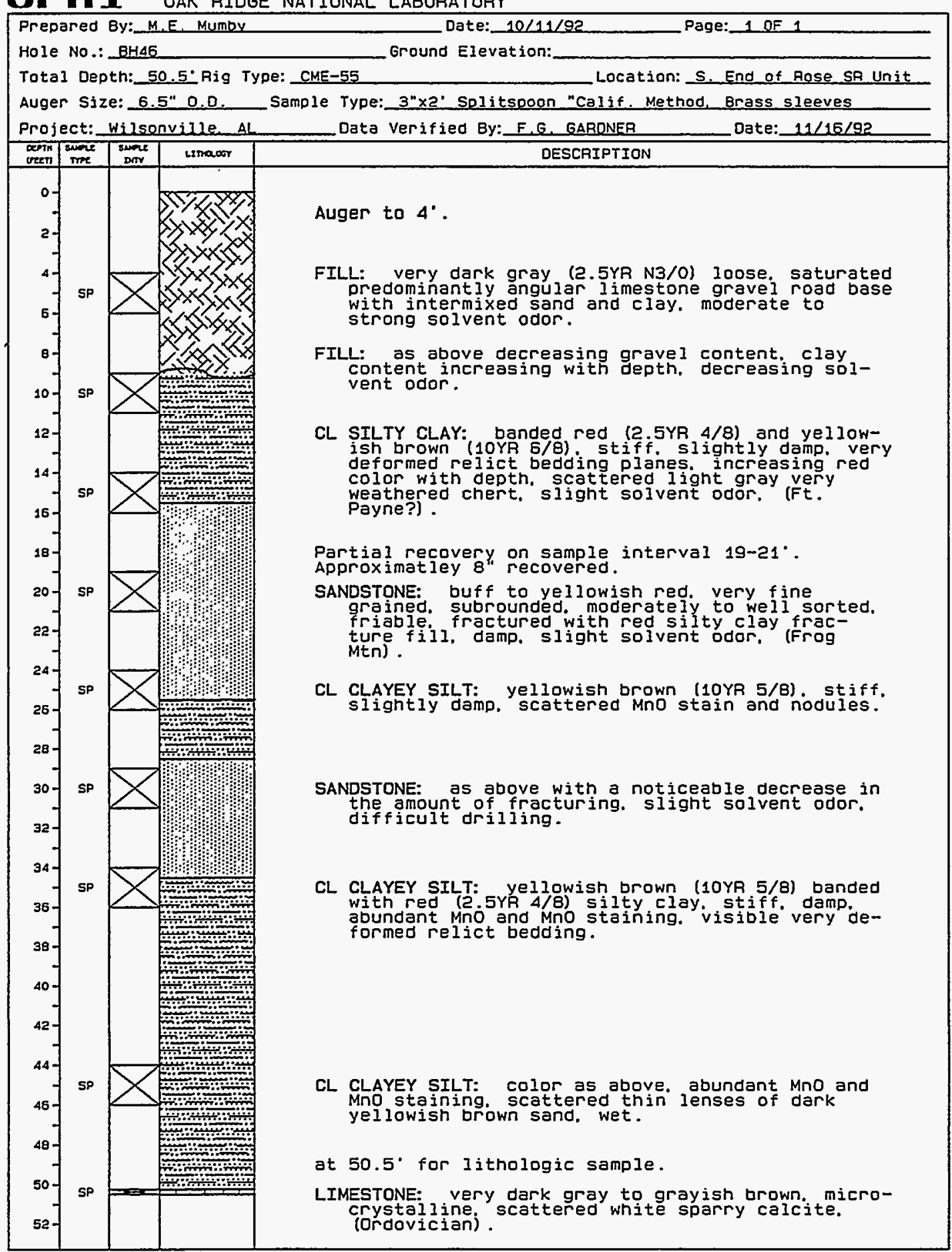


OrII OAK RIOGE NATIONAL LABORATORY

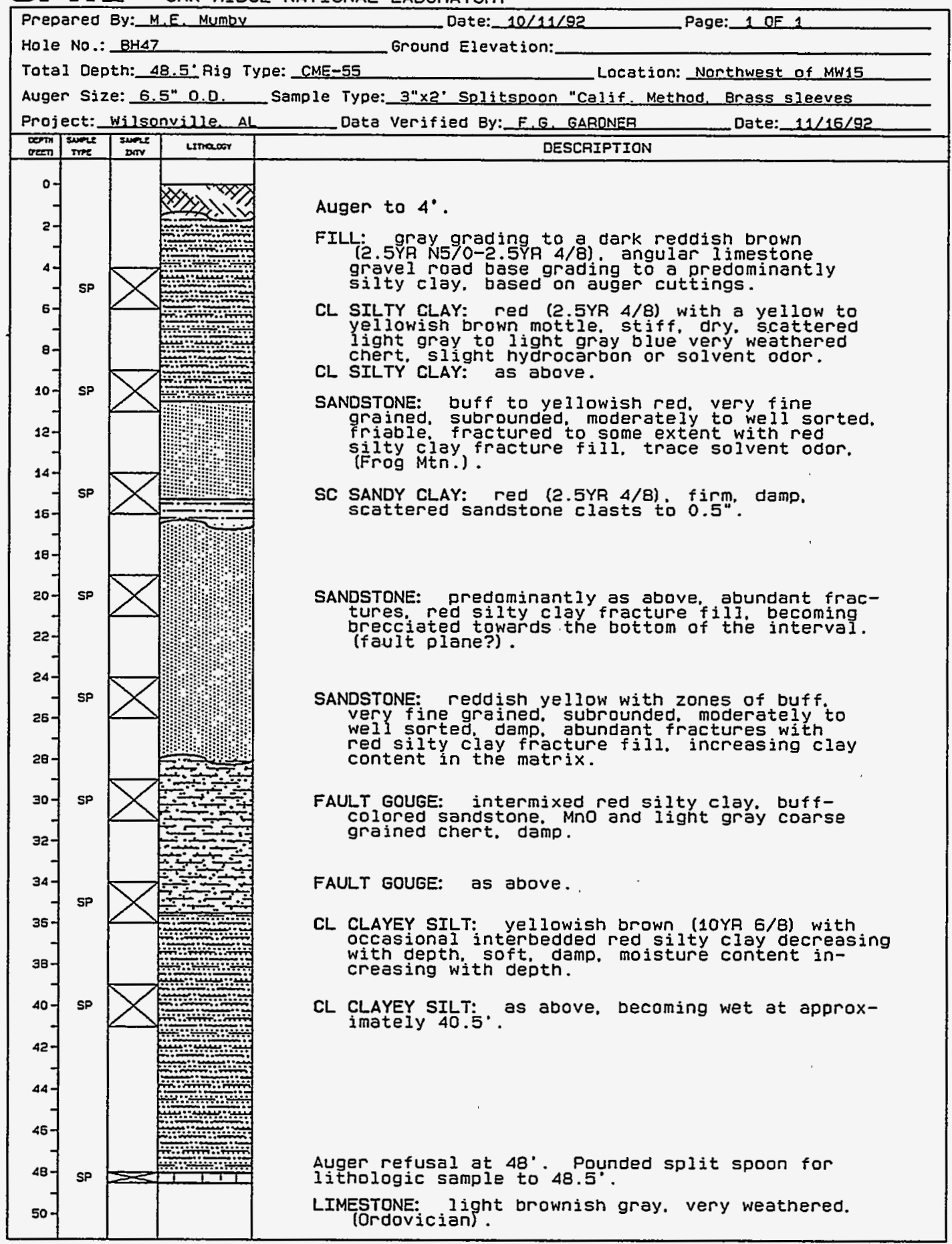




\section{OrII OAK RIDGE NATIONAL LABORATORY}

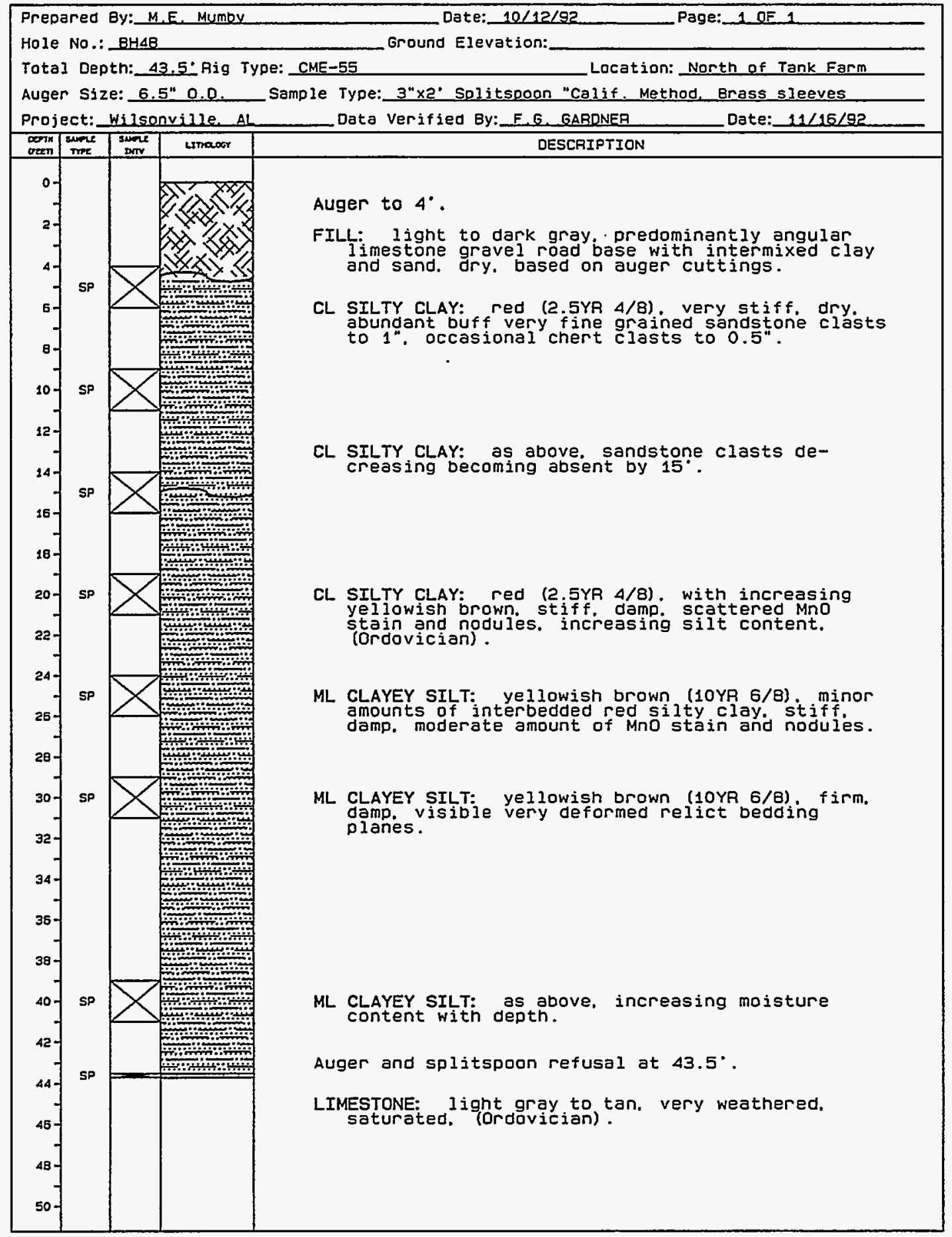


orn1

Borehole Summary Information

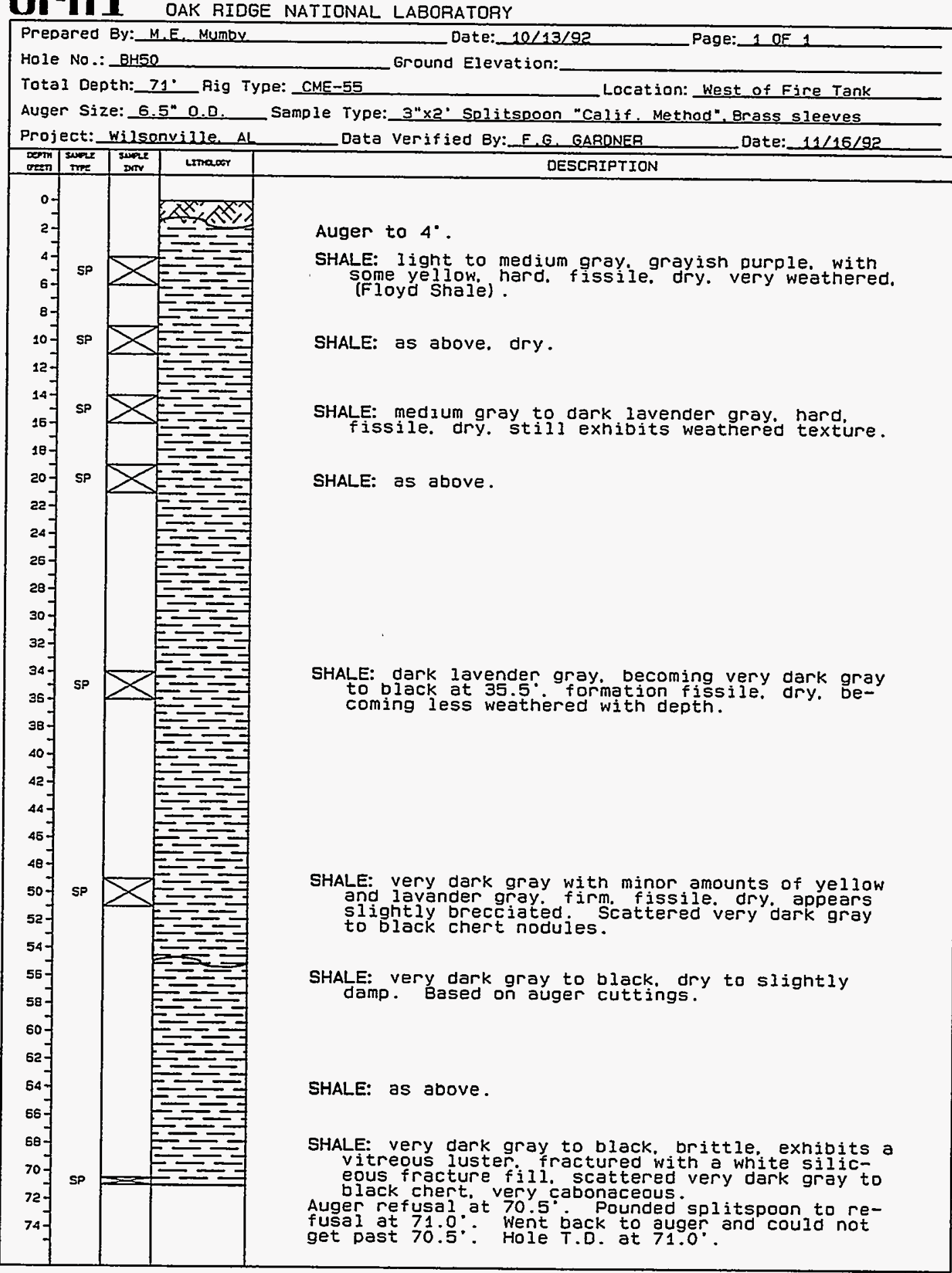


Dr 1 Borehole Summary Information

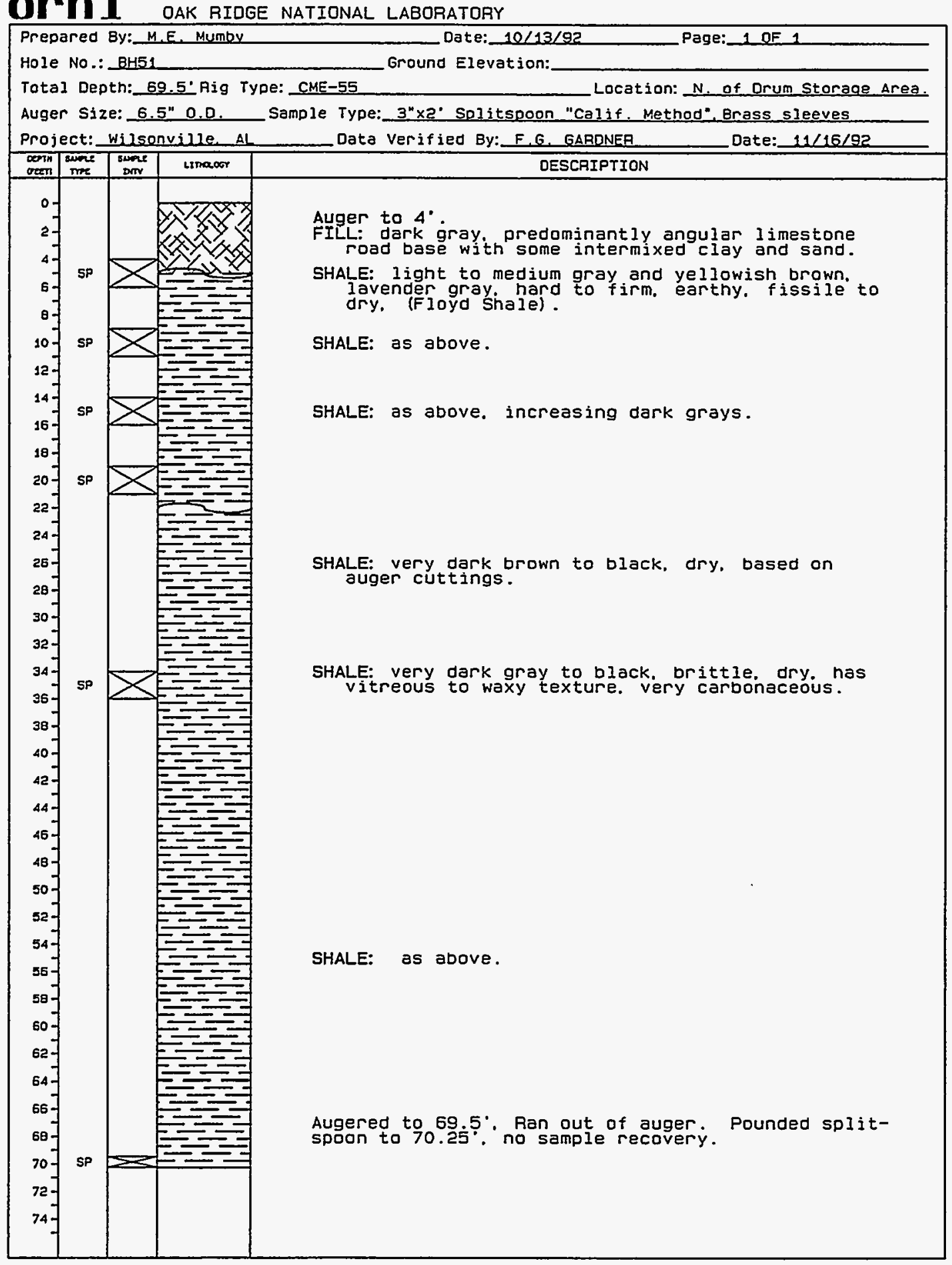


OII 1 OAK RIDGE NATIONAL LABORATORY Summary Information

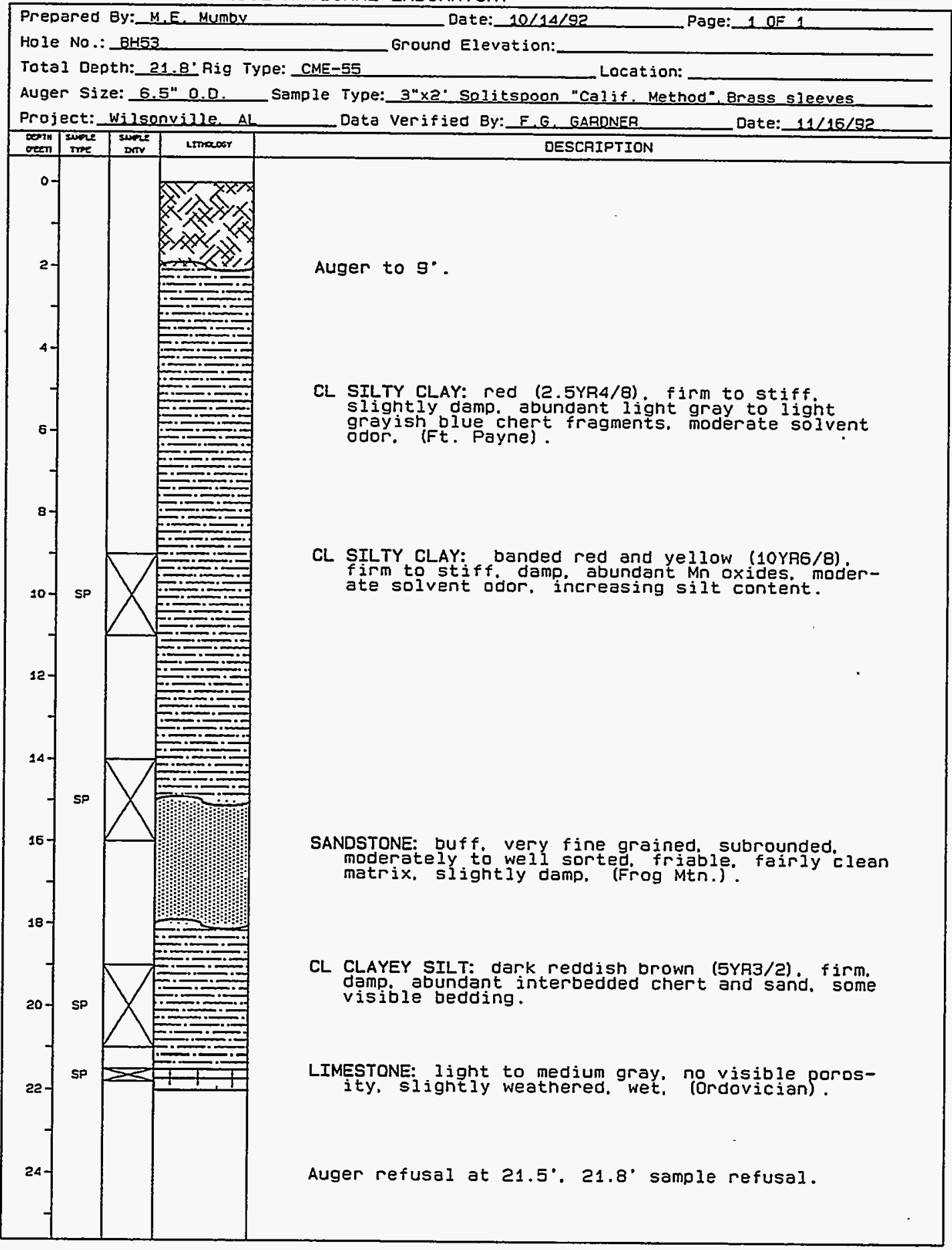


arn 1 oak RIDGe national LaboRatory

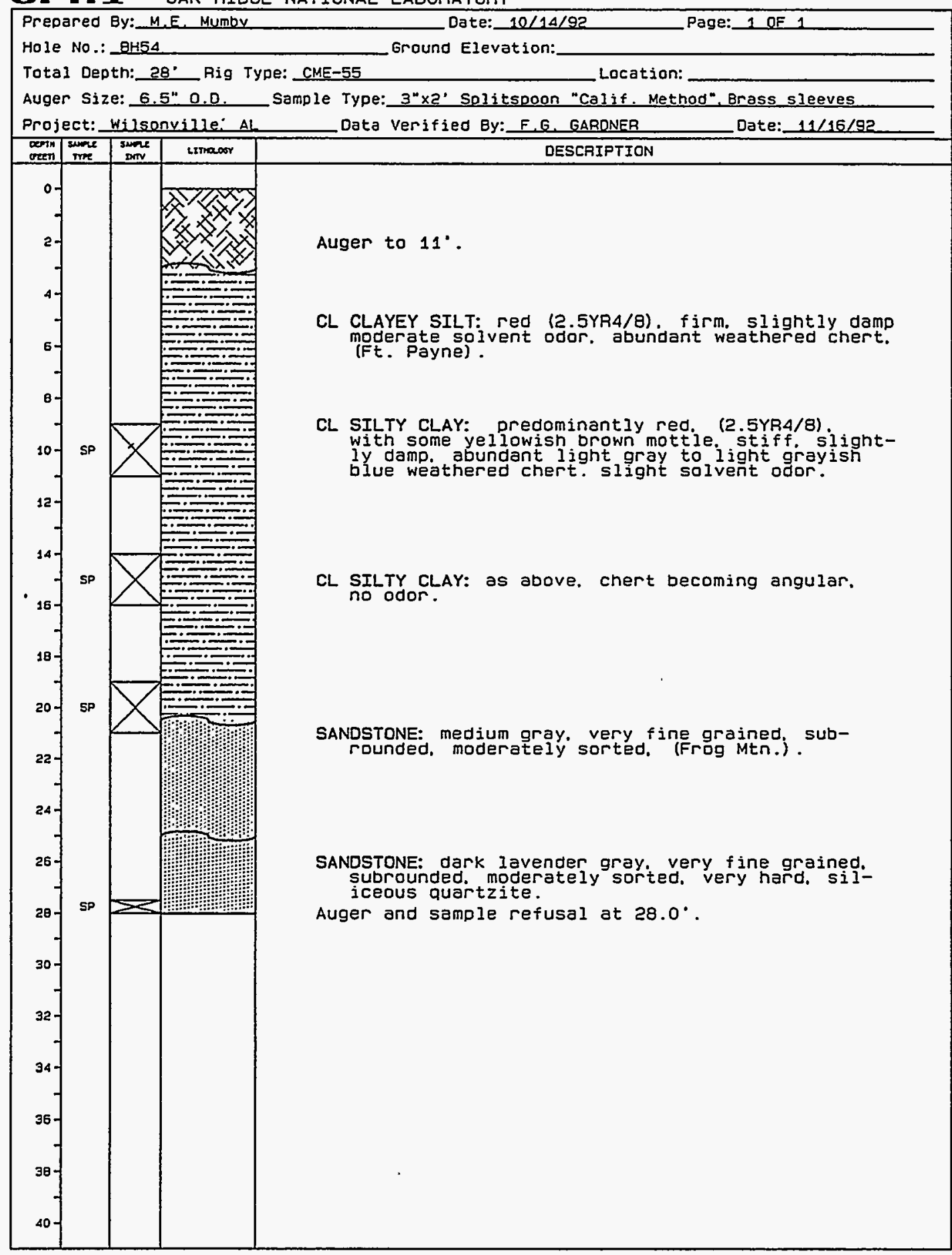


orin 1

Borehole Summary Information

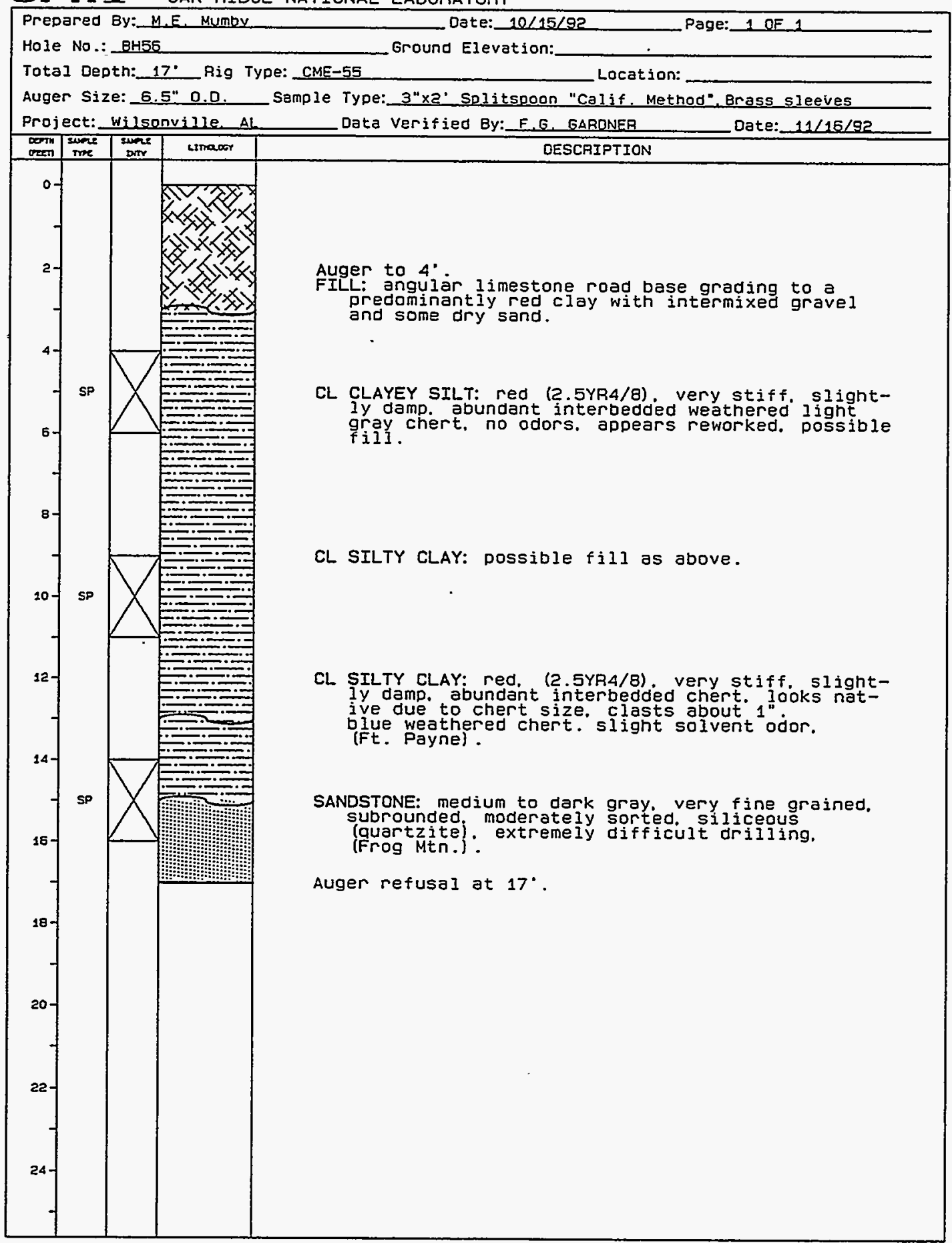


QII OAK RIDGE National LaboratoRy

$$
\text { Borehole Summary Information }
$$

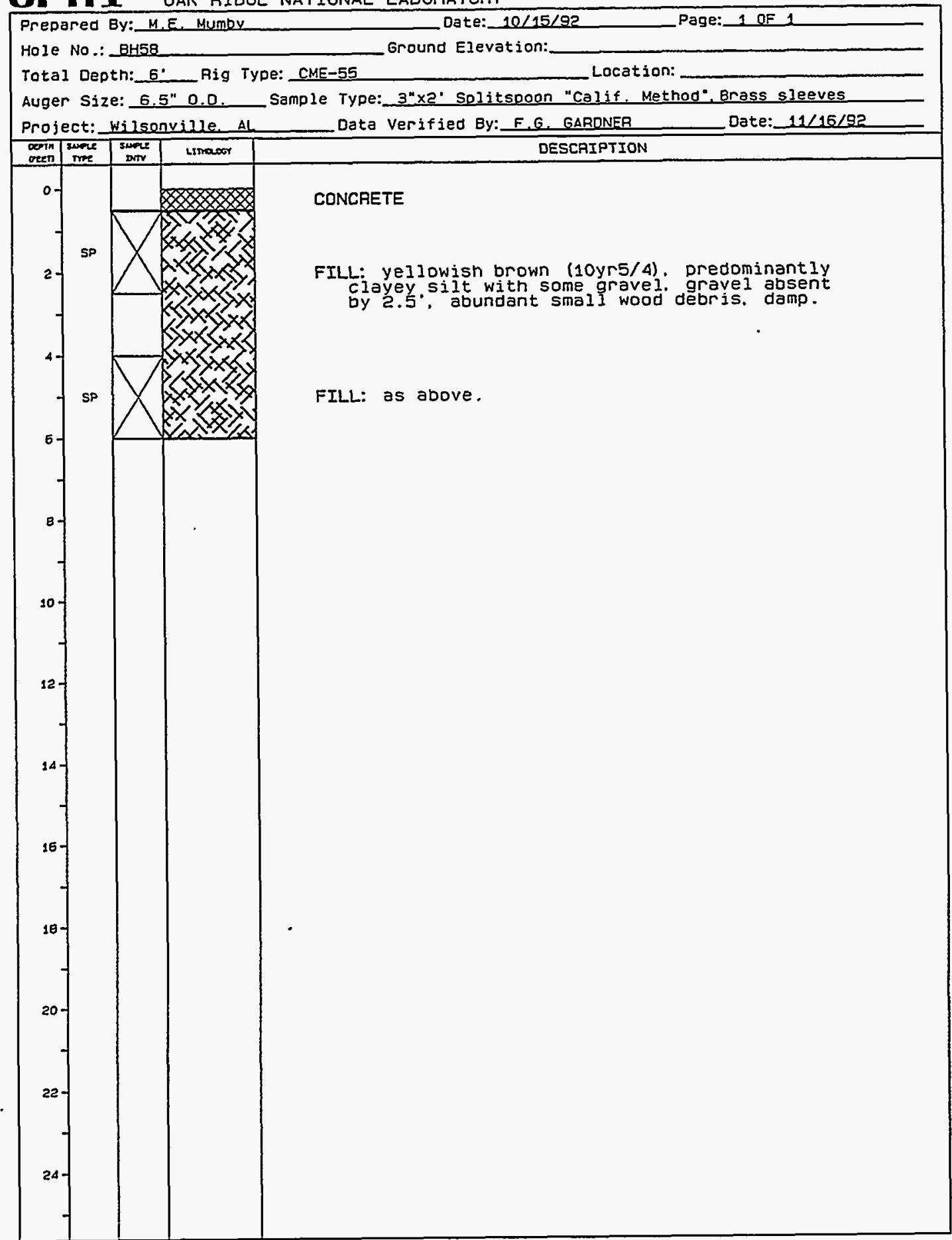


orn]

Borehole Summary Information.

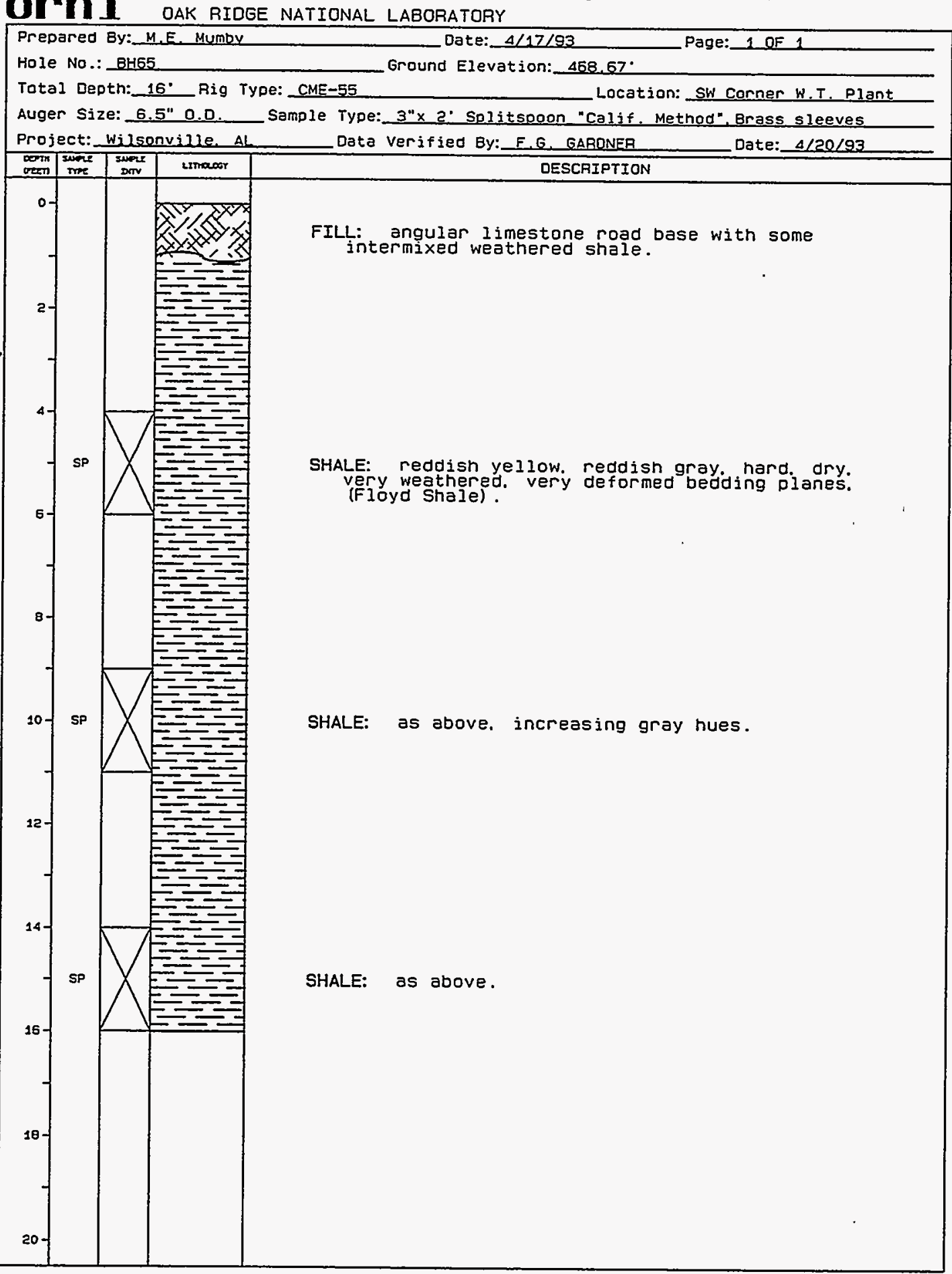


QIII OAK RIDGE NationaL LaboRatory

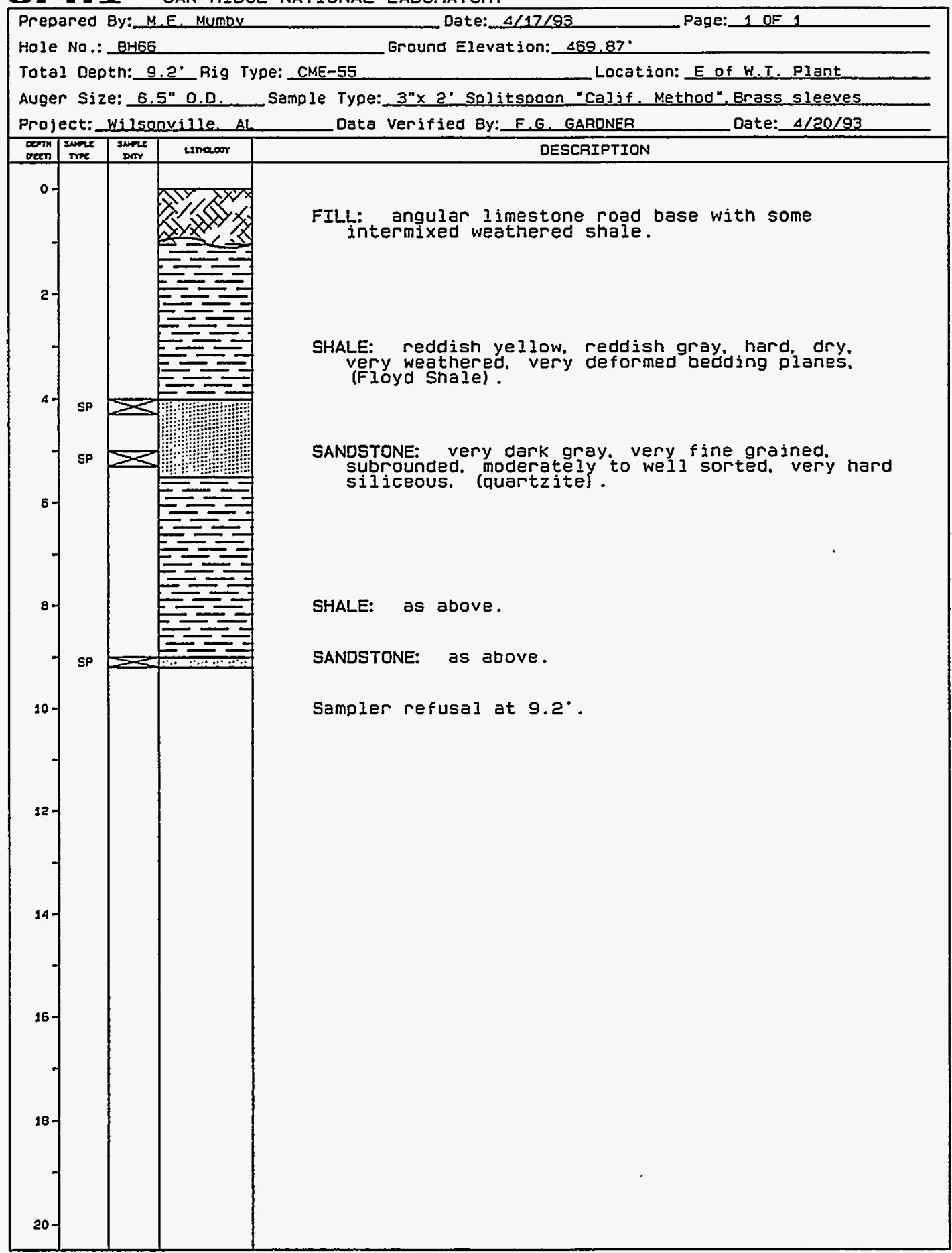


orn1

Borehole Summary Information

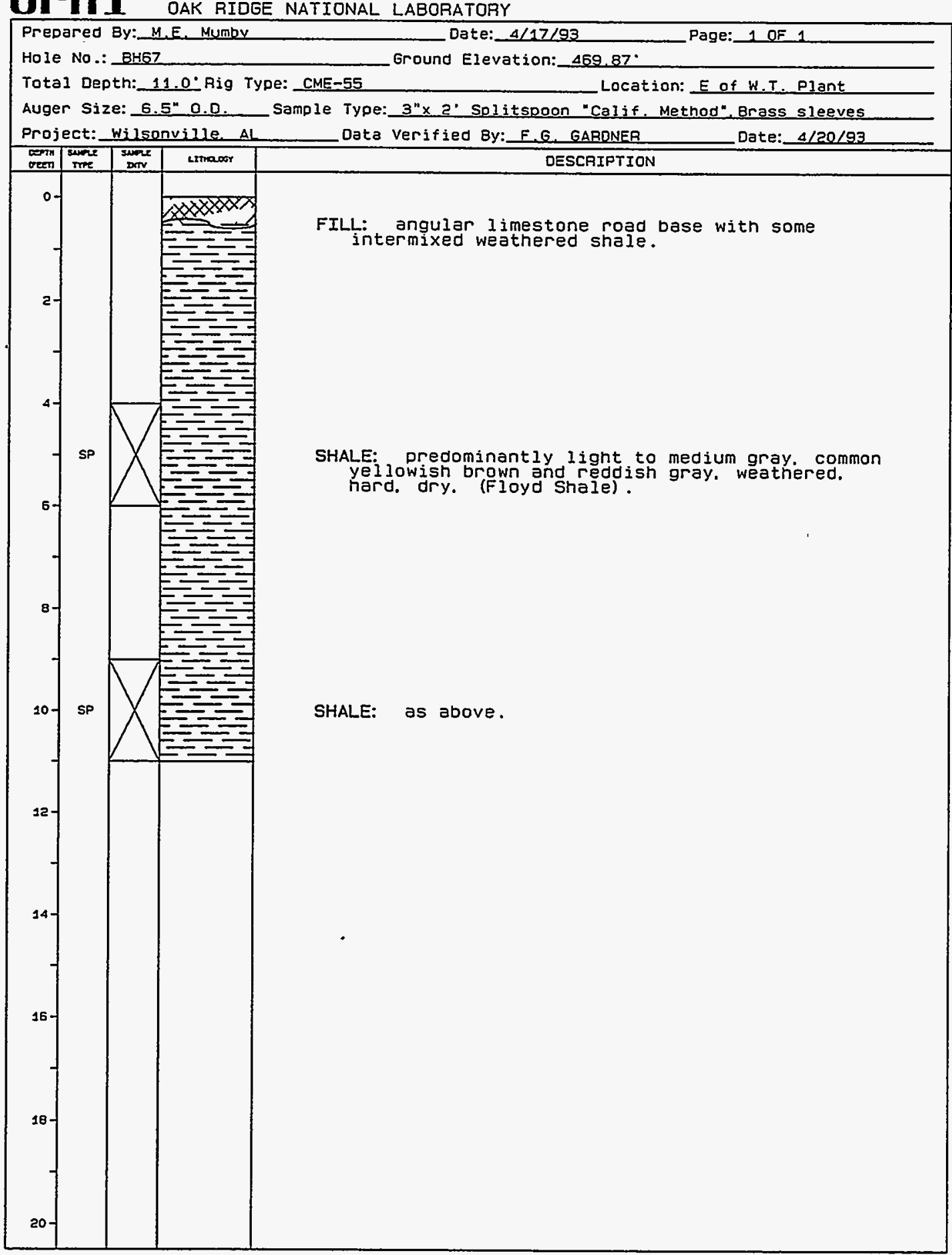


orn 1

Borehole Summary Information

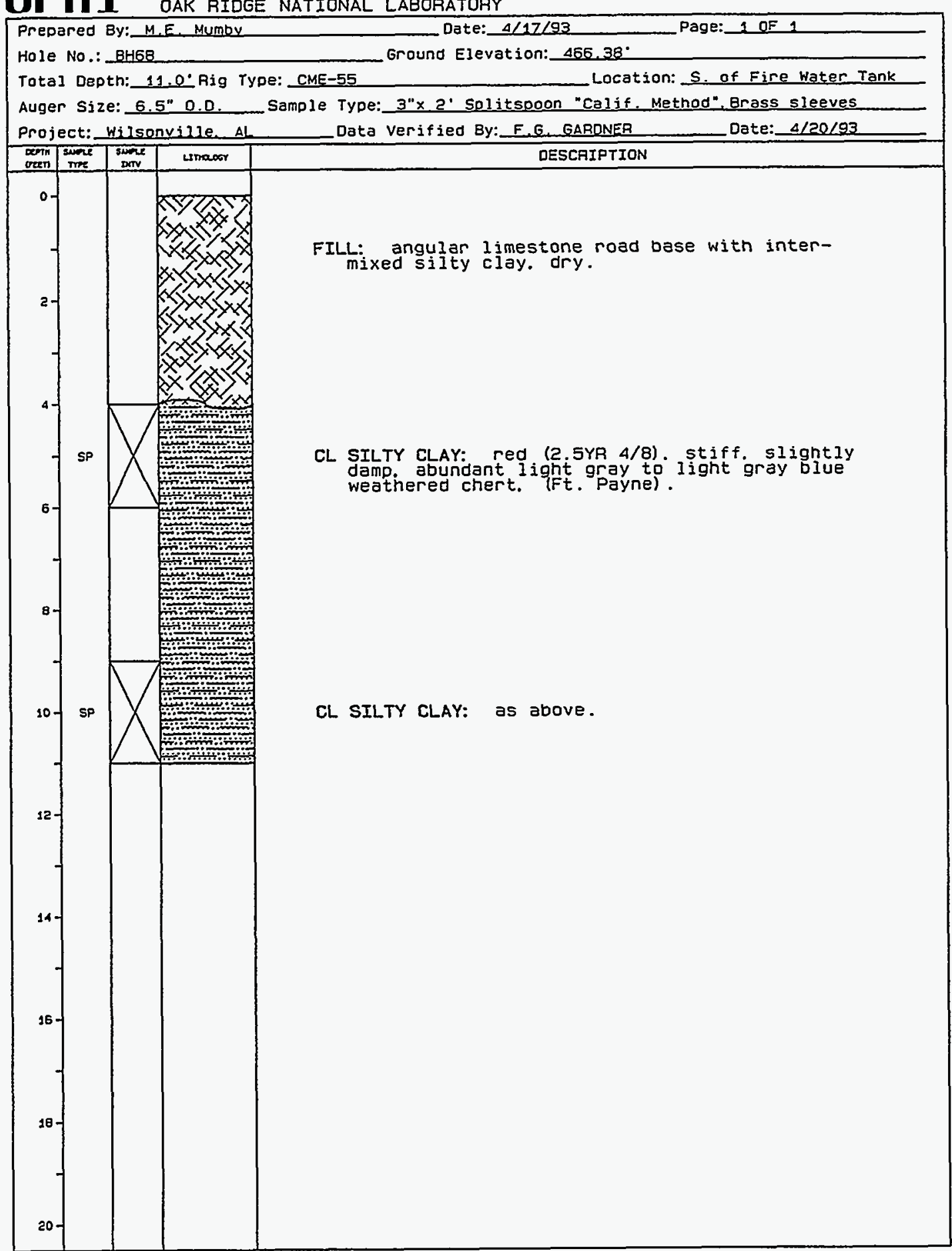


OII OAK RIDGE NATIONAL LABORATORY

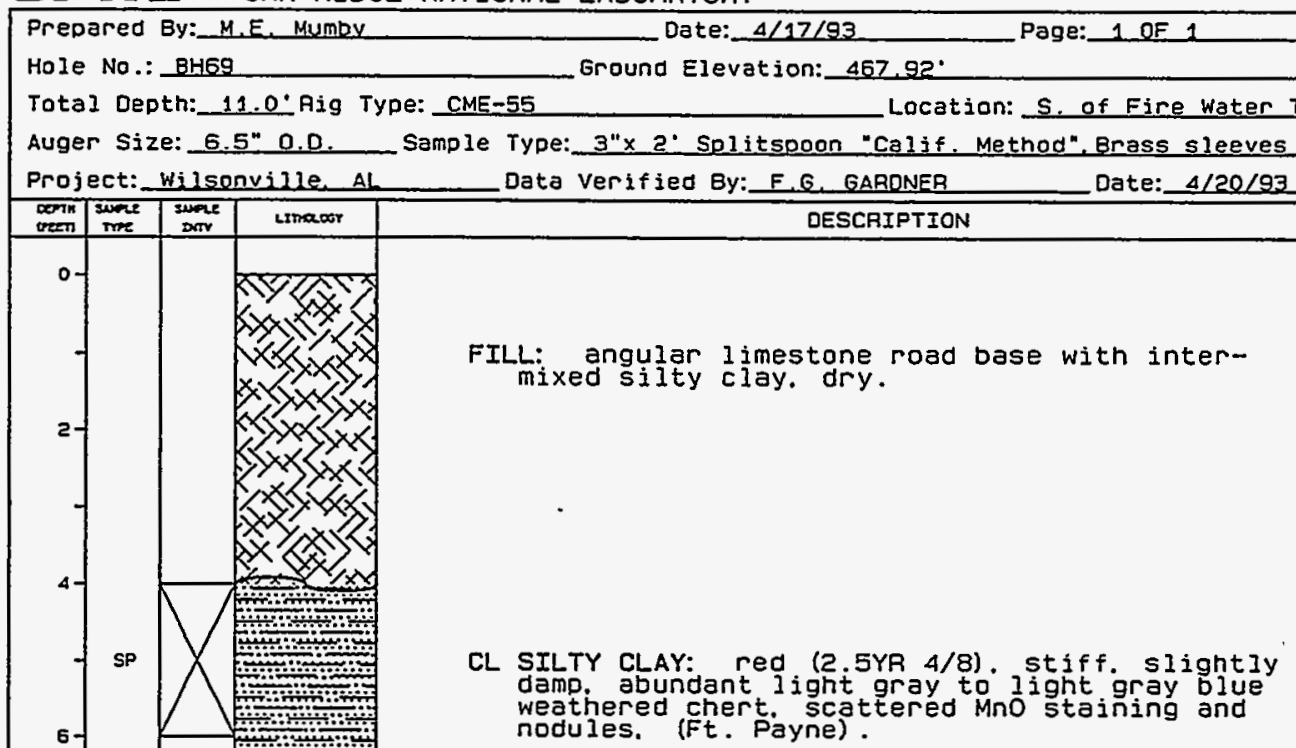

demp abundant light gray to light gray blue nodules. (Ft. Payne).

CL SILTY CLAY: as above. 
DIII. OAK RIDGE NATIONAL LABORATORY

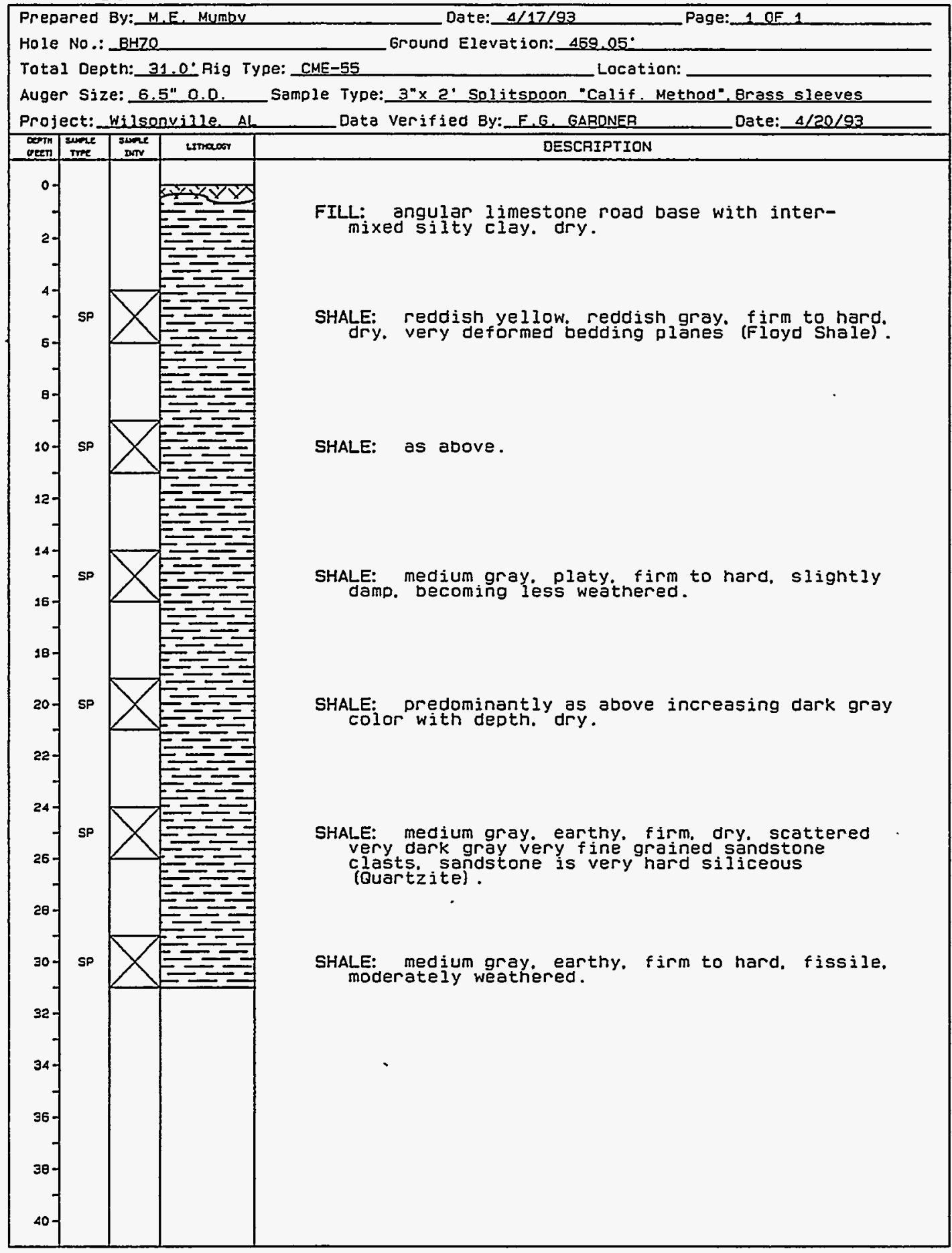


OrI 1 oak Ridge national LaboratoRy

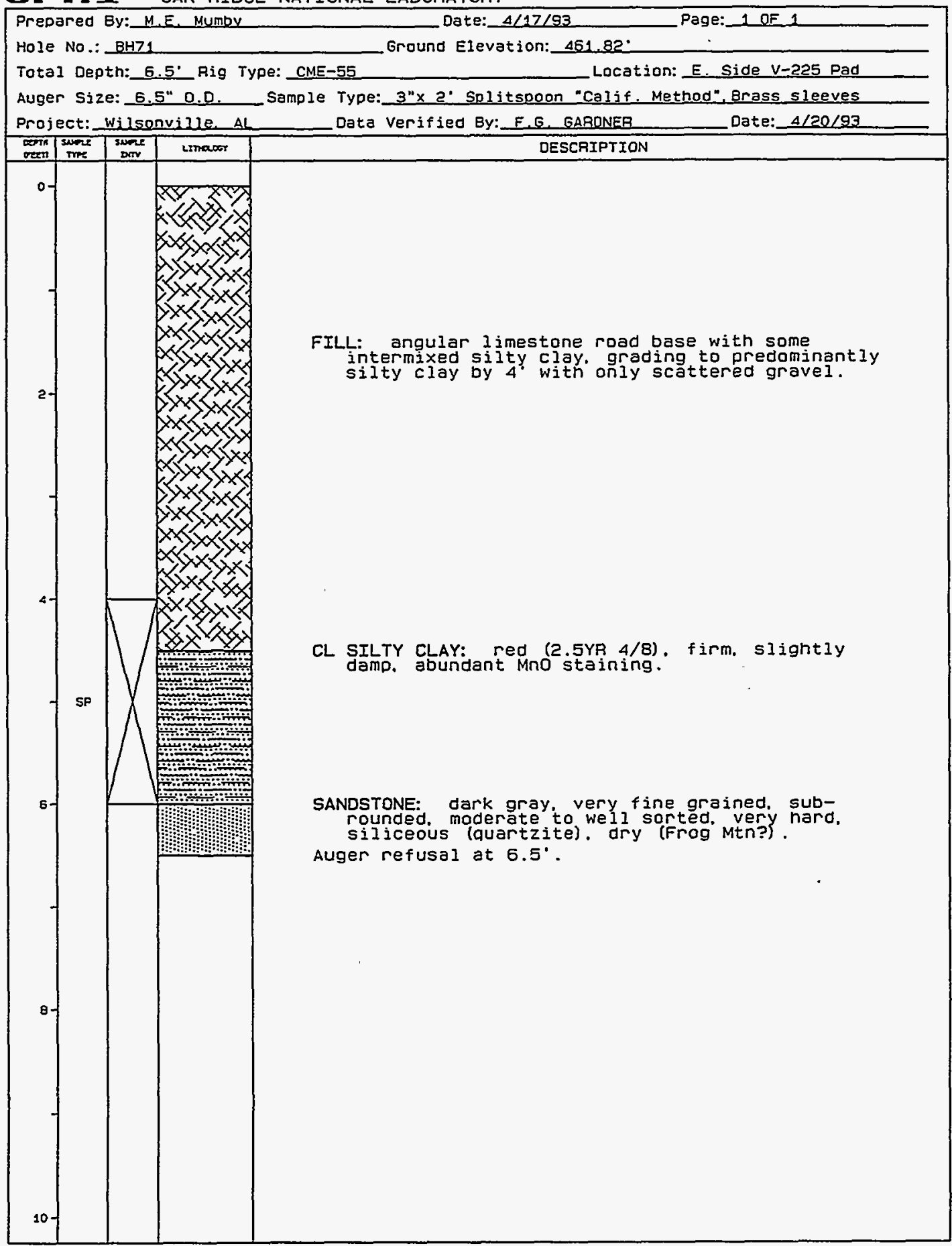


arn 1 OAK RIDGE NATIONAL LABORATORY

Borehole Summary Information

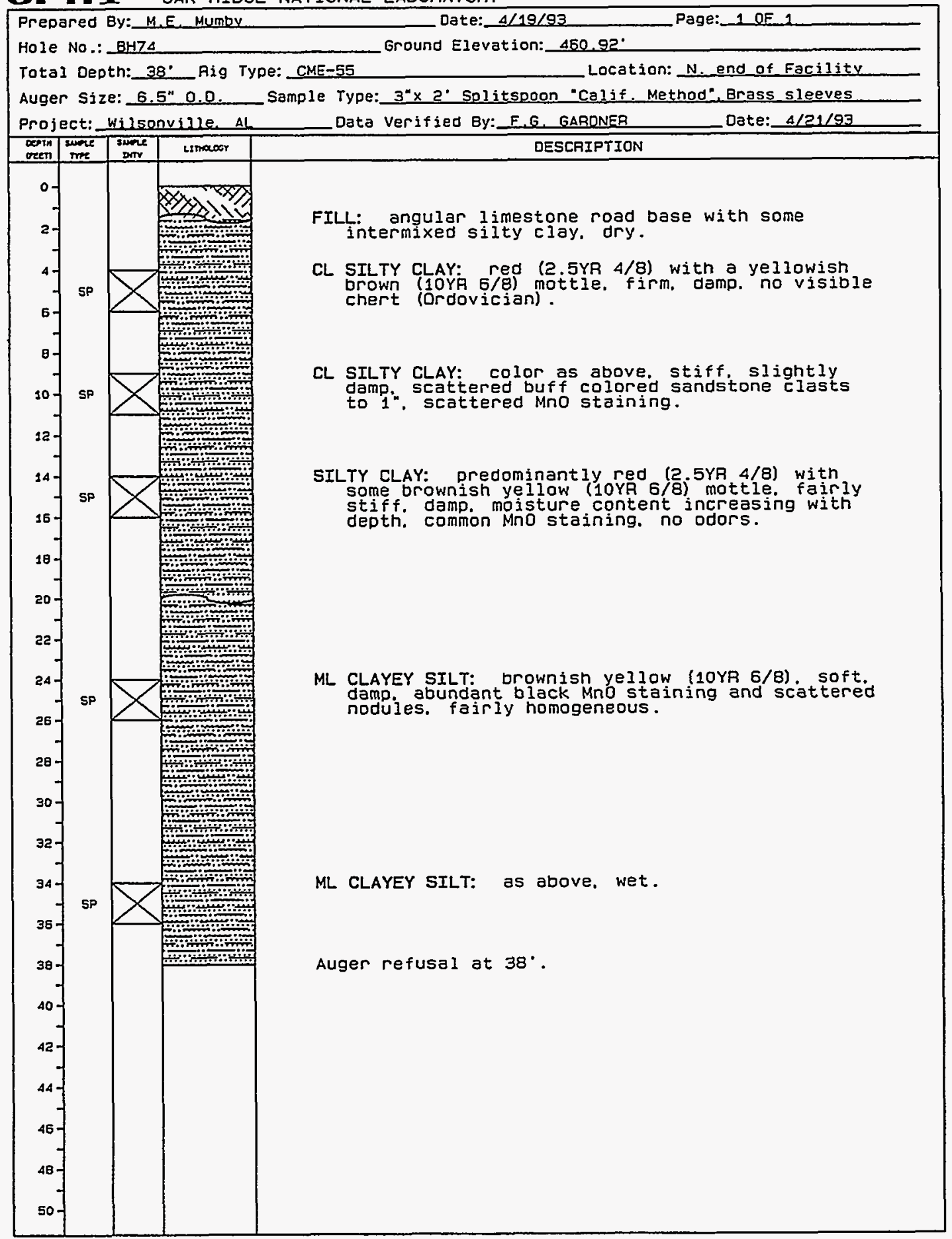


Or] Borehole Summary Information

NAL LABORATORY

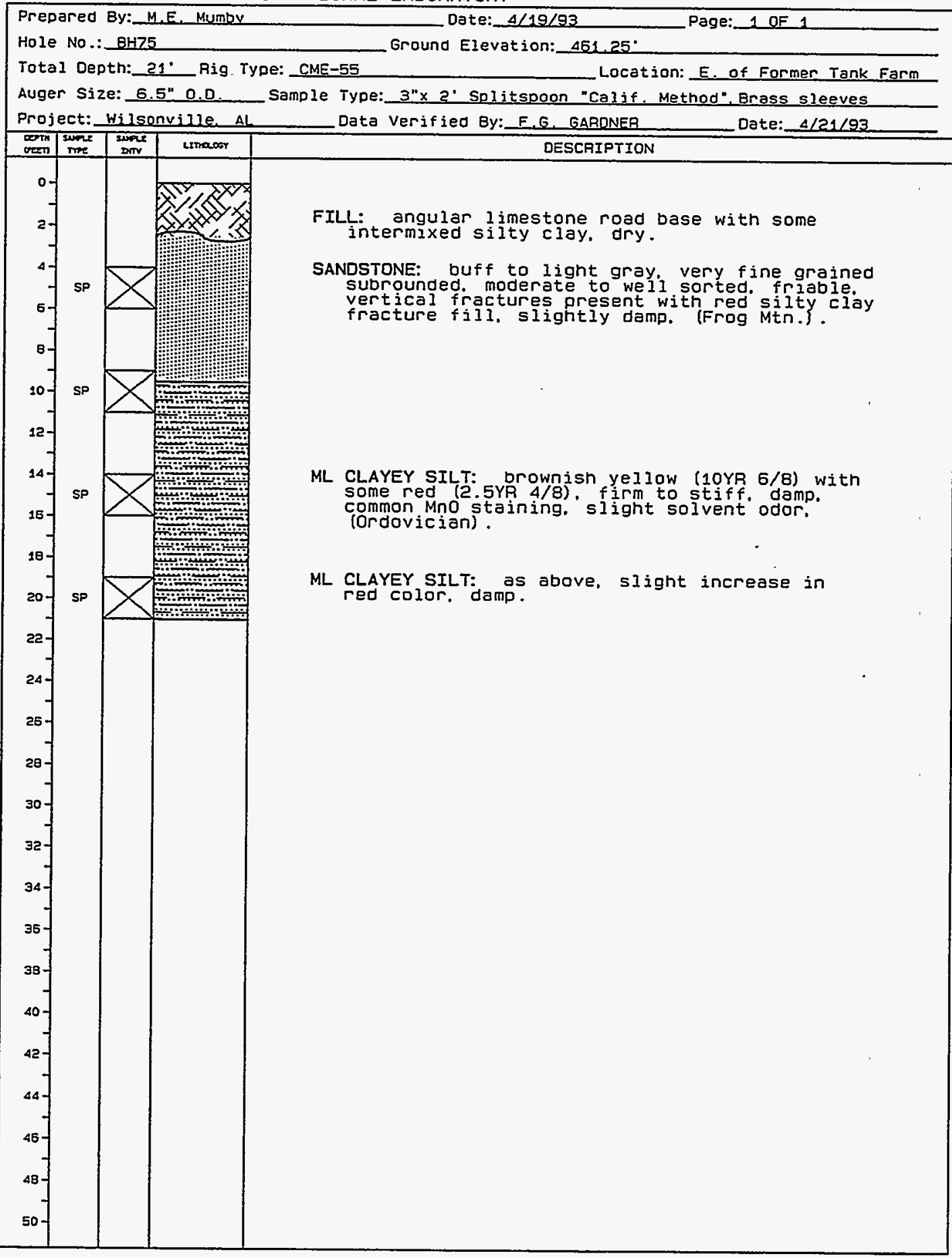




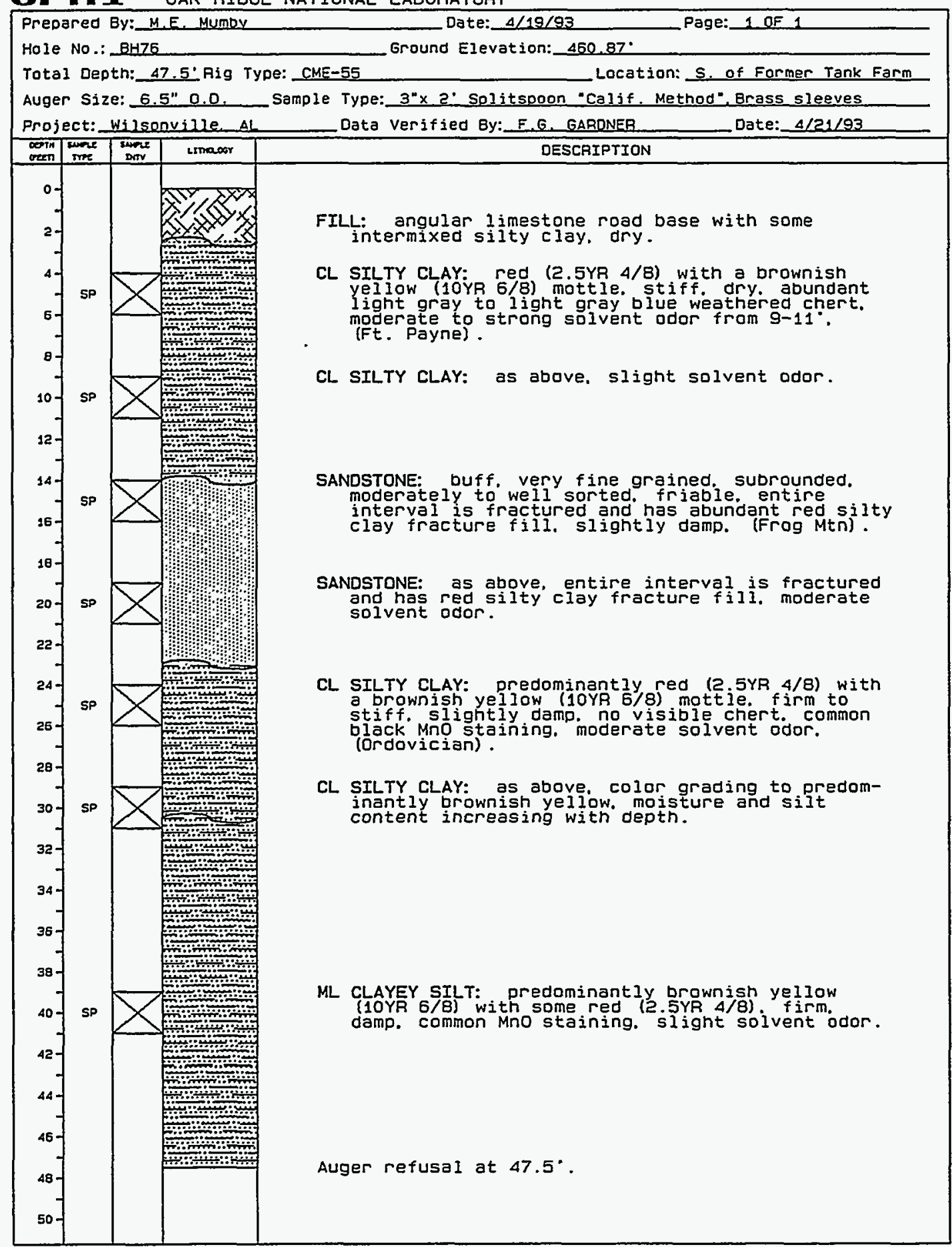


orn 1

Borehole Summary Information

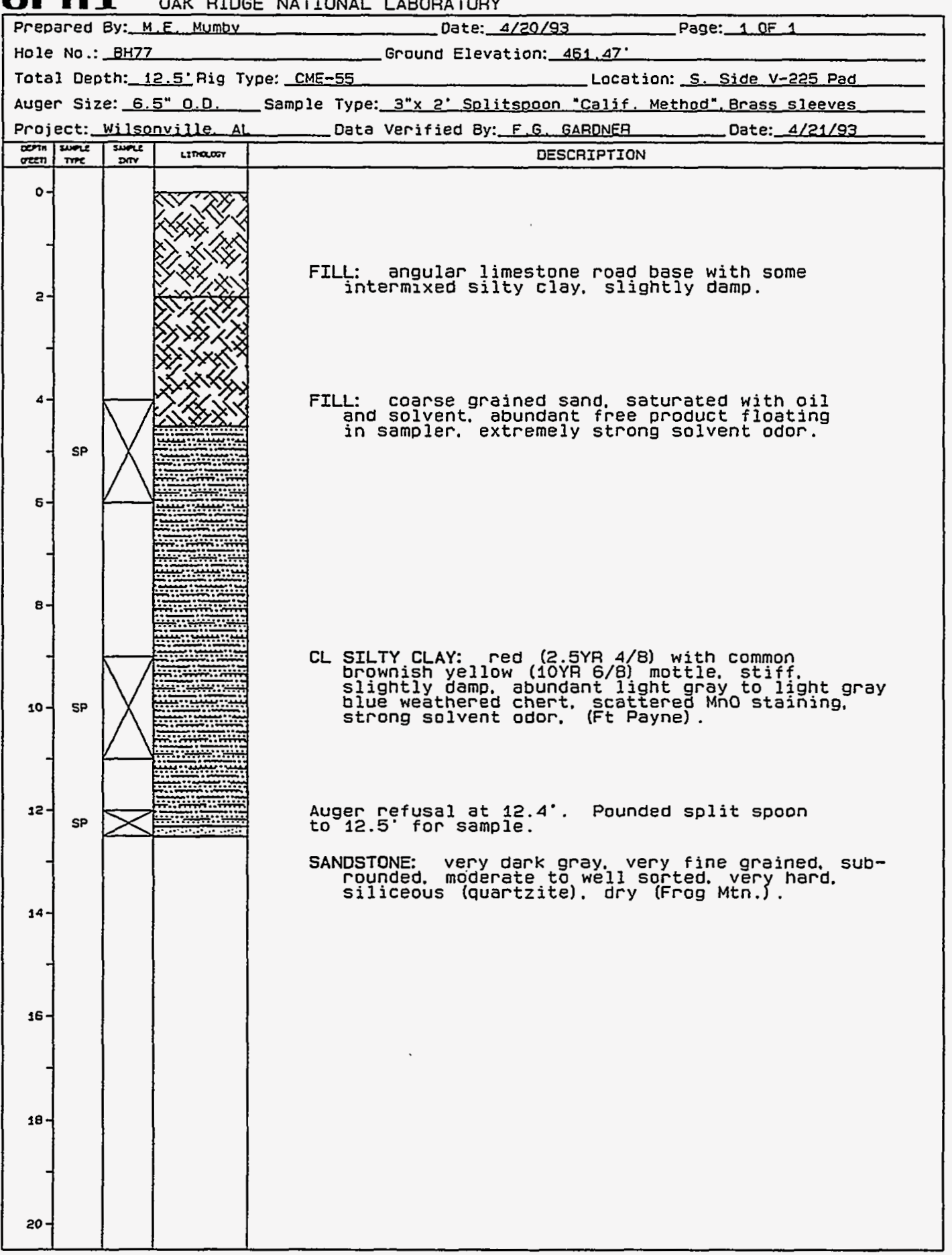




\section{INTERNAL DISTRIBUTION}

1. B. A. Berven

2 - 6. F. G. Gardner

7 - 11. P. M. Kearl

12- 16. N. E. Korte

17 - 21. C. A. Little

22 - 26. M. E. Mumby

27. P. T. Owen
28. M. J. Wilson-Nichols

29. Central Research Library

30 - 31. Laboratory Records

32. Laboratory Records-RC

33. ORNL Patent Section

34. ORNL Technical Library, Y-12

\section{EXTERNAL DISTRIBUTION}

35. Richard Esposito, Southern Company Services, P.O. Box 2625, Bin B457, Birmingham, Alabama 35202.

36. David Frings, Senior Geologist, Power Generation Services/Civil Alabama Power Company, 600 North 18th Street, P.O. Box 2641, Birmingham, Alabama 35291.

37 - 41. Shelby Rogers, Pittsburgh Energy Technology Center, P.O. Box 10940, Pittsburgh, Pennsylvania 15236-0940.

42. Office of Assistant Manager, Energy Research and Development, P.O. Box 2001, Oak Ridge, TN 37831-8600.

44 - 45. Office of Scientific and Technology Information, U.S. DOE, P.O. Box 62, Oak Ridge, TN 37831. 


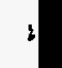

